\title{
Membrane Trafficking of Integral Cell Junction Proteins*
}

\author{
Arie Horowitz \\ Faculty of Medicine, Normandy University, France
}

\begin{abstract}
Though membrane trafficking of cell junction proteins has been studied extensively for more than two decades, the accumulated knowledge remains fragmentary. The goal of this review is to synthesize the numerous and disparate observations on the membrane trafficking of the five major junction transmembrane proteins accumulated to date to comprehend the current state of the art, to highlight differences and similarities among the trafficking pathways, and to identify topics that are not fully understood. Clathrin-mediated endocytosis appears to be the main but not exclusive mode of internalization. Caveolin-mediated endocytosis and macropinocytosis are employed less frequently. PDZ-domain binding is the predominant mode of interaction between junction protein cytoplasmic tails and scaffold proteins. It is shared by claudins, the largest family of junction integral proteins, and by the three nectins. All five proteins are destined to either recycling via Rab4/Rab11 GTPases or to degradation. The sorting mechanisms that underlie the specificity of their endocytic pathways and determine their fates are not fully known. New data is presented to introduce an emerging role of junction-associated scaffold proteins in claudin membrane trafficking.
\end{abstract}

\section{INTRODUCTION ${ }^{1}$}

Despite being no more than a single-cell thick, the endothelial and epithelial cell layers that form the luminal surface of blood and lymph vessels and of numerous tubular organs (e.g., the lung tracheal, the digestive, and the ureteric systems), respectively, are the only barriers that prevent breaching of the walls of each system and, concomitantly, its dysfunction. The cytoplasmic faces of adherens [263] and tight [270] junctions that maintain monolayer integrity harbor protein complexes which provide structural support and continuity from the junction transmembrane proteins to the cytoskeleton. These intricate molecular assemblies that recycle constantly even in quiescent cells $[52,59,210]$ undergo extensive remodeling in response to agonists such as vascular endothelial growth factor (VEGF), transforming growth factor (TGF)- $\beta$, sphingosine-1-phosphate (S1P), and plateletderived growth factor (PDGF) $[68,70,116,160]$. The molecular mechanisms that determine their membrane trafficking from and to the cell junctions are not fully known. It is not clear if they employ individual membrane trafficking pathways or if they share common ones.

Survey of studies reported mostly during the last two decades reveal that despite the attention given to the subject of intercellular junction remodeling, the grasp of this process is still fragmentary. Conceptual progress on cell junction dynamics is hampered by their structurally and functional complexities. While there are only two or three species of junction transmembrane proteins in adherens [146] and in tight junctions [270], respectively,

\footnotetext{
${ }^{*}$ Has not been submitted for publication

${ }^{\dagger}$ Correspondence: Faculty of Medicine, 22 Boulevard Gambetta, 76183 Rouen Cedex, Normandy, France; arie.horowitz@inserm.fr

${ }^{1}$ Nomenclature: names of the proteins mentioned in the review follow current nomenclature rather than names used in the reviewed studies to increase clarity and uniformity (e.g., catenin p120 is named $\delta$-catenin).
}

some of them consist of protein families of multiple members. Moreover, they bind cytoplasmic protein complexes of varying compositions and sizes that mediate numerous signaling pathways and which interface with the cytoskeleton. A further layer of complexity is conferred by the diversity of membrane trafficking routes and endosomes encountered by different junction transmembrane proteins.

Much of the data on cell junction dynamics reported to date was derived from epithelial cells and the organs they populate. Though it cannot be assumed by default that all the molecular mechanisms that control cell junction dynamics in epithelial cells are identical to the analogous mechanisms in endothelial cells (ECs), their observed similarities suggest that they are shared to a large extent. In a few cases, the review considers data obtained from fibroblasts used to express epithelial or EC junction proteins free of the confounding effects of the endogenous proteins. The review does not address desmosomes, which do not form in ECs, or gap junctions, which have been studied primarily as electrophysiological interfaces.

Intercellular junction proteins redistribute from the plasma membrane (PM) to the cytoplasm constitutively or in response to agonists such as VEGF in ECs [70], or epithelial growth factor (EGF) in epithelial cells [25]. Once internalized, they have one of two possible fates: recycling back to the PM $[153,178]$, or proteolysis in lysosomes or proteosomes $[42,254]$.

For reasons that are related in part to the multiple functions of the catenins that bind their cytoplasmic domains [143], the membrane trafficking of cadherins is better known than that of all other intercellular junction transmembrane proteins, whereas that of nectins, the second adherens junction transmembrane protein species, is known the least.

The objective of this review is not to cover exhaus- 
tively all studies that have a bearing on membrane trafficking of junction proteins, but, to the extent possible, extract patterns and derive organizational principles. Because of the volume of the data and to maintain focus, the review addresses only the five major integral proteins of adherens and tight junctions. The cell systems, agonists, and experimental methods are specified in order to facilitate evaluation of the relevance and validity of the conclusions of the reviewed studies.

The accompanying schemes in figures 1-5 represent syntheses of the reviewed studies on each of the five tight and adherens junction transmembrane proteins. They are intended to provide an 'at a glance' overall view of these pathways while maintaining the connection with the text by associating each component with one or more relevant studies. Figure 6 presents new data which indicates that the large junction-associated scaffold protein multiple PDZ domain protein (MPDZ) is involved in claudin membrane trafficking.

\section{CLAUDINS}

Numbering 27 known human genes, claudins are the largest family of intercellular junction transmembrane proteins $[79,126]$. The variety of claudins may reflect tissue-specific expression of their genes, and/or differences in the extent of sealing they confer on tight junctions. Claudins are 210-305 amino-acid-long tetraspan proteins with cytoplasmic amino- and carboy-termini (Fig. 1). The majority of claudins harbor a post-synaptic density95/Discs large/Zonula occludens (PDZ)-binding motif at their carboxy-termini [79], implying that their recruitment to tight junctions or to trafficking pathways is mediated by proteins that harbor PDZ domains. Whereas most members of the claudin family genes are expressed in epithelial cells, their subsets vary among host organs. A smaller number of claudin genes are expressed in ECs. In mouse brain capillaries, the expression levels of Cldn5 and Cldn11 are predominant, but multiple sources indicate that Cldn1, 3, 10, 12 and 20 are also expressed at significant levels in mouse brain capillary ECs [171]. Claudin strands on abutting cells can form heterophilic interactions, though only a small number of combinations had been reported [67]. Claudin-1, a prototypical member of the family, was observed to undergo constitutive recycling in several epithelial cell types [52]. Further observations recounted bellow suggested this behavior is shared among numerous claudins in epithelial and endothelial cells.

\subsection{Endocytosis}

The predominant endocytic pathway of the claudins is clathrin-mediated. Calcium depletion of human colon carcinoma epithelial cells resulted in claudin- 1 and claudin-4 collocation with the clathrin heavy chain and with the clathrin adaptor protein $\alpha$-adaptin (AP2A1) [22, 100]. Their removal from the cell junctions was blocked by cytosolic acidification, sucrose-induced hypertonic stress, and phenylarsine oxide, all of which block clathrinmediated endocytosis $[87,156,200]$. The endocytosed claudins were recruited to early endosomes [131]. Because claudins 1 and 4 collocated in that compartment with syntaxin-4, a t-SNARE that mediates docking of transport vesicles to the PM [16], it appears they were readied for reincorporation in the $\mathrm{PM}$ once intercellular junctions are restored [100]. In contrast to the effect of hypertonic stress, the induction of hypotonic stress by halving the osmolarity of the medium induced endocytosis of claudin-1 and -2 in Madin-Darby canine kidney (MDCK) cells. Its blockage by pharmacological inhibition of dynamin, a GTPase required for the scission of clathrincoated vesicles [40], or of clathrin polymerization, indicated that claudin- 1 and -4 underwent clathrin-mediated endocytosis [62]. The endocytosed claudins were targeted to lysosomal degradation, as indicated by their collocation with lysosome-associated membrane protein (LAMP) 1 marker [33].

The homologous carboxy-terminus PDZ-binding motif shared by 20 members of the claudin family underlies the similarity of their membrane trafficking pathways. A missense mutation that replaced threonine in the -2 position of the motif to an arginine (T233R) was linked to familial hypomagnesaemia with hypercalciuria and nephrocalcinosis (FHHNC) [157], a genetically inherited form of kidney failure. Unlike native claudin-16, the mutant did not bind zona occludens (ZO)-1 when expressed in MDCK cells. When triggered to undergo constitutive endocytosis by temperature elevation to $37 \circ \mathrm{C}$, claudin-16 was located in lysosomes instead of intercellular junctions. Though junction recruitment appeared to require the PDZ-binding motif, endocytosis evidently occurred in its absence because a claudin- 16 with a missense L203X mutation, which truncates most of its intercellular carboxy-terminus domain including the PDZ-binding motif, was retained at the cell junctions when constitutive clathrin-mediated endocytosis was inhibited

citepRN231,RN236. However, the abundance of the L203X mutant at the cell junctions was substantially lower than the wild-type (WT) variant and, unlike the latter, was present throughout the cytoplasm (ibid.).

Clathrin-mediated endocytosis was induced by several physiological and pharmacological agonists. EGFinduced claudin-2 binding to the clathrin heavy chain and $\alpha$-adaptin in MDCK epithelial cells [95]. The endocytosed claudin-2 traversed early endosomes and collocated with LAMP1, but not with the Golgi apparatus, suggesting it was targeted for lysosomal degradation rather than recycling. Cevimeline, a specific agonist of the M1 and M3 muscarinic acetylcholine (Ach) receptors [9], as well as carbachol, a non-selective Ach receptor agonist ana$\log$, induced claudin- 4 binding to clathrin and to the endocytic sorting protein arrestin- $\beta 2$ in immortalized rat salivary gland epithelial cells [39]. This effect was specific to claudin, as the interaction of occludin and epithelial (E)-cadherin with arrestin- $\beta 2$ were not altered by carbachol. The latter finding is in agreement with the M3 receptor specificity to arrestin- $\beta 2$ [104]. The clathrin dependence of claudin- 4 endocytosis was established by showing that it was blocked by pharmacological inhibition of dynamin [135] by siRNA-mediated knockdown of the clathrin heavy chain, and by hypertonic sucrose medium. 


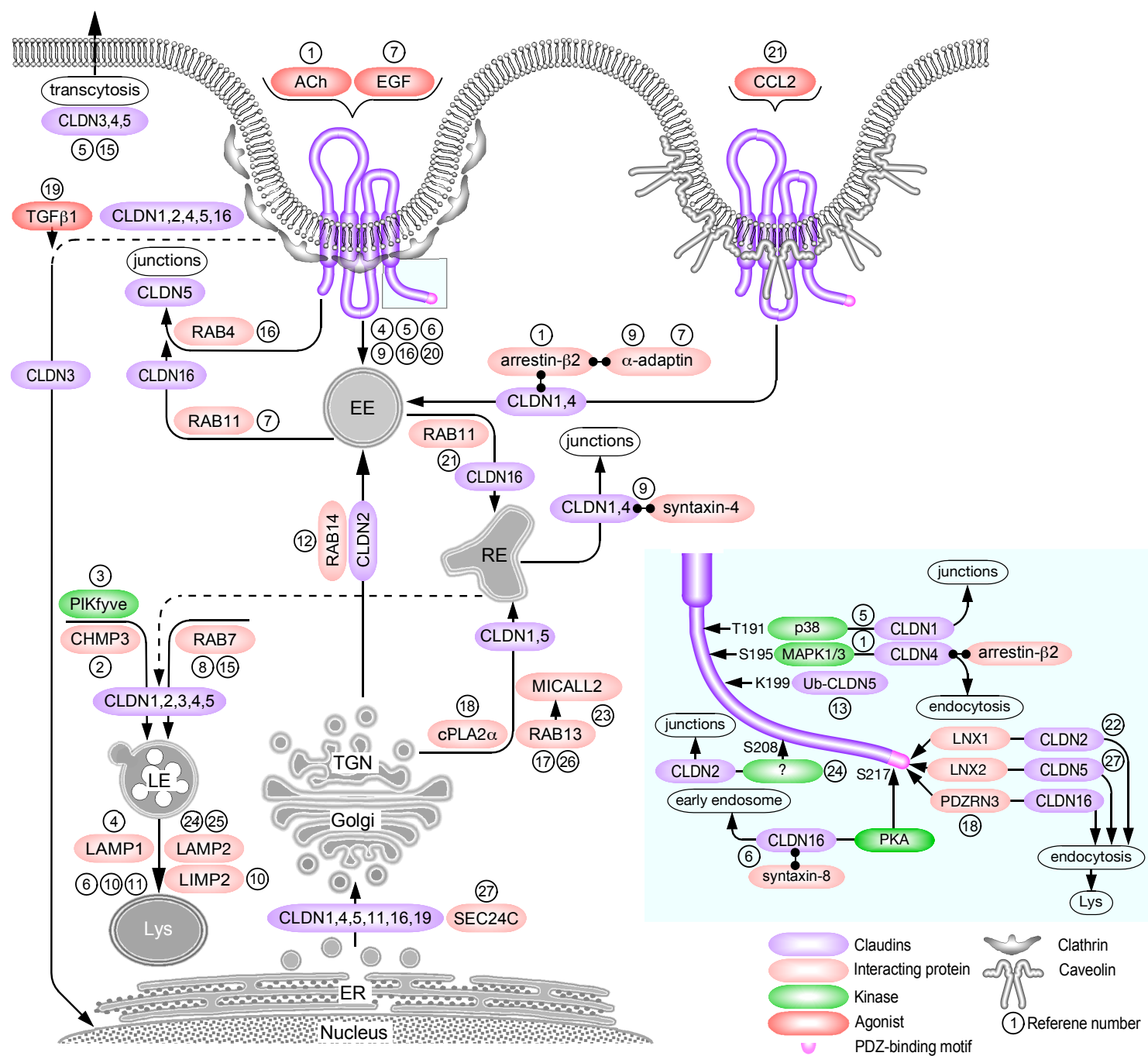

Figure 1: Scheme of membrane trafficking pathway of claudins. This and the following figures synthesize the studies discussed on each of the transmembrane junction protein. Inset shows phosphorylation sites and binding proteins to the claudins' cytoplasmic domain. Dashed lines indicate speculative features. EE, early endosome; LE, late endosome; Lys, lysosome; RE, recycling endosome. Numbers correspond to the following references: (1) [39], (2) ([52], (3) [53], (4) [62], (5) [71], (6) [94], (7) [95], (8) [96], (9) [100], (10) [127], (11) [128], (12) [132], (13) [137], (14) [139], (15) [141], (16) [158], (17) [168], (18) [192], (19) [203], (20) [217], (21) [219], (22) [227], (23) [231], (24) [242], (25) [243], (26) [258], (27) [264].

Endocytosed claudin-4 was ubiquinated and underwent proteasomal degradation. Dissociation of trans-binding claudins located on adjoining Caco-2 and human embryonic kidney (HEK)-293 epithelial cells by peptidomimetics of the first extracellular loop of claudin-1 induced clathrin-mediated endocytosis of endogenous claudin-1 and -5 [217]. Because the endocytosis was a direct result of the release of the mechanical coupling between claudins rather than the downstream effect of specific agonists or cell culture conditions, this result is arguably the most generic indication that the default internalization mechanism of claudins is clathrin-mediated endocytosis. Uniquely among all the junction transmembrane proteins discussed in this review, claudin-3 redistributed from the tight junctions of primary human bronchial epithelial cells to their nuclei in response to TGF $\beta 1$ downstream of TGF receptor 1 [203]. The endocytic pathway and the nuclear entry mechanism of caludin-3 were not specified. Putative nuclear recognition signals had been identified in a major- ity of the claudins, and some of them had been observed in nuclei, but only in the context of cancer [80].

Aside from endocytosis into the parental cell, claudins underwent transcytosis into adjoining cells. During wound closure of monolayers of Eph4 or MDCK cells expressing GFP or FLAG (DYKDDDDK), respectively, fused to the amino-terminus of claudin-3 [141], cells of either type harbored cytoplasmic vesicles containing both endogenous claudin-3 and GFP or FLAG-fused claudin3. This indicated that there was no preference between parental and transfected cells or between WT and recombinant claudins in the direction of transcytosis. The frequency of transcytosis was higher among dispersing subconfluent cells, suggesting that transcytosis resulted from mechanical tension along the intercellular junctions produced by cells pulling apart from each other. While the claudins were pinched off from the PM into tubular structures together with JAMA, occludin and ZO1, they were sorted subsequently into claudin-only vesicles. 
Constitutive transcytosis of claudin- 4 or -5 overexpressed in MDCK cells, each fused at its amino-terminus to a different species of fluorescent protein, internalized simultaneously all the transmembrane proteins present on the transcytosed PM region. The endocytic vesicles contained both species of claudins as well as endogenous claudin- $1,-2$, or -7 , or occludin [71]. The single aminoacid substitutions F147A and Q156E in the second extracellular loop of claudin-5, which impair homophilic transbinding [183], reduced transcytosis frequency. Remarkably, transcytosis was inhibited by either chlorpromazine, an inhibitor of adaptor protein (AP)-2 complex binding to clathrin [248], or by filipin, which interferes with caveolae assembly by the removal of cholesterol from the PM [205], though the effect of filipin was less robust than chlorpromazine's. Paradoxically, the dynamin-specific pharmacological inhibitor dynasore [135] appeared to have no effect on transcytosis, in conflict with the effective chlorpromazine-induced inhibition. Collocation with the microtubule-associated protein 1A/1B-light chain 3 (MAP1LC3B) and with autophagy related protein $16 \mathrm{~L}$ (ATG16L) indicated the transcytosed claudins were targeted to autophagosomes. Accumulation in the cytoplasm upon chloroquine administration suggested that they were next destined to lysosomal degradation [251], similar to the observation of Matsuda et al. [141].

While there is abundant evidence for the dependence of monolayer barrier function on claudin phosphorylation $[8,46,47,61,257]$, the specific effect of phosphorylation on membrane trafficking is less documented. In quiescent MDCK cells, claudin-16 was phosphorylated constitutively [94] by cyclic adenosine monophosphate (cAMP)dependent protein kinase (PK)-A, as the phosphorylation was blocked by the several PKA and adenylyl cyclase inhibitors and restored by cAMP. Single site mutations of potentially phosphorylatable serines pinpointed the PKA-phosphorylation to S217 in the claudin-16 carboxyterminal cytoplasmic domain. Dephosphorylated claudin16 did not associate with ZO1 and was located predominantly in the cytoplasm or in lysosomes. Claudin-16 phosphorylated on S217 was recruited to the cell junctions and bound the soluble N-ethylmaleimide-sensitive factor attachment protein receptor (SNARE) syntaxin-8 [185], which mediates endocytosis of cell membrane proteins and fusion of endocytic vesicles to early endosomes [194]. The phosphorylation of claudins- 3 and -5 was also attributed to PKA $[46,215]$. S208 in the cytoplasmic domain of claudin-2 was phosphorylated in quiescent MDCK cells maintained in serum-containing medium [242]. A phosphomimetic S208E mutant was detected at the cell edges, suggesting that S208 phosphorylation induced claudin-2 recruitment to cell junctions. Concordantly, the majority of the S208A dephosphomimetic mutant population was in the cytoplasm and collocated with the lysosomal marker protein LAMP2 [33]. Mutations that reduced the recruitment of claudin-2 to the cell junctions, such as the removal of the carboxy-terminus PDZ-binding motif, were accompanied by a lower phosphorylation level, suggesting that the unidentified kinase that phosphorylated S208 is located on the cytoplasmic leaflet of the PM.

Binding of claudin- 4 to arrestin- $\beta 2$ in carbachol-treated immortalized rat salivary gland epithelial cells was linked to phosphorylation of S195 in the carboxy-terminus cytoplasmic domain of claudin-4 [39]. The phosphorylation was attributed to MAPK1/3 because it was inhibited by PD98059, its pharmacological inhibitor [4], and by U0126, a pharmacological inhibitor of the phosphorylation and activation of MAPK1/3 by MAPKK1/2 [50]. S195 phosphorylation was required for clathrin-mediated endocytosis of claudin-4. Hypotonic stress induced phosphorylation and endocytosis of claudin- 1 and -2 in MDCK cells [62] that was attributed to MAPK p38 (MAPK14) because the it was blocked by SB202190, its specific pharmacological inhibitor [57]. Based on previous studies $[2,213,242]$, the phosphorylated residues were assumed to be T191 in claudin-1 and S208 in claudin-2. This premise was supported by the resistance of the phosphomimetic claudin-1 and -2 mutants T191E and S208E, respectively, to their removal from the cell junctions by hypotonic stress. Conversely, the dephosphomimetic mutants T191A and S208A were segregated to the cytosol and collocated with the late endosome marker Rab7 and the lysosomal marker LAMP1.

Claudin-5 underwent caveolin/lipid raft-mediated endocytosis in mouse brain primary ECs in response to the monocyte chemoattractant [3] chemokine C-C ligand (CCL)-2 [219] based on the collocation of claudin-5 with cholera toxin, a marker of caveolin-mediated endocytosis and on the inhibition of claudin-5 endocytosis by cholesterol depletion. Collocation with either caveolin or a lipid raft marker was not shown.

\subsection{Recycling}

The recruitment of claudins from the Golgi apparatus to intercellular junctions required the activity of cytosolic phospholipase A2 alpha (cPLA2)- $\alpha$, an enzyme that generates arachidonic acid involved in the formation of cytoplasmic tubular membranes [204]. In subconfluent human umbilical cord ECs (HUVECs) cPLA2 $\alpha$ and claudin-5 were located in separate cytoplasmic punctae [192]. There was a reciprocal relationship between the cellular locations of cPLA $2 \alpha$ and claudin-5: when the cells reached confluence, inactive cPLA2 $\alpha$ was present in the Golgi apparatus [86], whereas claudin-5 was located at intercellular junctions. Depletion of cPLA2 $\alpha$ by knockdown of its gene, PLA2G4A, or by pharmacological inhibition by pyrrolidines [206], was accompanied by the removal of claudin-5 from the cell junctions and its accumulation in the Golgi apparatus, suggesting that cPLA2 $\alpha$ activity was required for claudin-5 trafficking from the Golgi to the junctions.

Rab13 plays a major role in the recruitment of tight junction transmembrane proteins to cell junctions [140]. The recycling of claudin- 1 to the PM after recovery of MDCK cells from calcium depletion was slowed down by siRNA-mediated knockdown of Rab13, or by expression of the GTP hydrolysis-defective mutant Rab13Q67L [258]. The recycling required Rab13 binding to its effector molecule interacting with CasL-like 2 (MICALL2) [231], a 
filamentous (f)-actin and actinin- 4 binding proteins that drives f-actin crosslinking during intercellular junction assembly $[165,198]$. The trafficking pattern of Rab13 suggested that claudin-1 translocated from the trans Golgi network (TGN) to recycling endosomes, and from them to the PM [168].

Claudins employ several trafficking pathways and multiple Rab GTPases that are determined in part by the conditions the cells are subjected to. Claudin-5 endocytosed in mouse brain microvascular ECs in response to C-C motif chemokine 2 (CCL2), a monocyte chemotactic cytokine [250], and collocated with Rab4 [219], a 'fast' trafficking GTPase [41]. It did not collocate with the lysosomal marker LAMP2, indicating it was recycled to the PM rather than degraded. In agreement, the recycling inhibitor bafilomycin-A1 [186] prevented the removal of claudin-5 from Rab4-containing vesicles. Disparately, in response to the deprivation of oxygen and glucose from the growth medium of bEND3-immortalized mouse brain ECs, claudin-5 underwent lysosomal degradation rather than recycling $[127,128]$. Claudin-16 recycling in quiescent MDCK cells was regulated by Rab11 [96], a 'slow' recycling GTPase [237]. Inhibition of Rab11 activity by either a dominant negative Rab11S25N mutant, or by primaquine, a pharmacological inhibitor of vesicle trafficking [216] decreased claudin-16 presence at the cell junctions in favor of collocation with the early endosome antigen (EEA) 1 and the lysosome marker lysosome membrane protein (LIMP)-2 [14]. The recycling of claudin-2 from the cytoplasm to the junctions of MDCK cells switched from incubation on ice to $37 \circ \mathrm{C}$ required the activity or Rab14 [132], a GTPase involved in trafficking from the TGN to early endosome [187]. Knockdown of Rab14 by short hairpin (sh) RNA resulted in claudin-2 targeting to lysosomes. Rab7, a late endosome marker [214], mediated the trafficking of transcytosed claudin- 3 and -4 to the lysosome in MDCK cells [141].

Similar to around a third of all translated proteins in eukaryotic cells (Dancourt and Barlowe, 2010), the translocation of claudin-1 from the endoplasmic reticulum (ER) to the Golgi apparatus occurs via membrane trafficking in coat protein complex (COP)-2 vesicles. The binding of claudin- 1 to the Sec24C subunit of COP2 [218] was shared by claudins $4,5,11,16$, and 19 [264], all of which have a tyrosine and valine at their carboxy-termini that functions as an ER export signal. These residues were required but not sufficient for Sec24c binding, which probably involves the whole claudin cytoplasmic domain. Expectedly, knockdown of Sec24c reduced the abundance of claudin-1 at the cell surface.

The endosomal sorting complex required for transport (ESCRT), a multi-protein assemblage that mediates membrane budding and scission in several cellular contexts [244] and the sorting of ubiquitinated cargo [106] was required for the constitutive recycling of claudin-1 in quiescent confluent MDCK cells [52]. Expression of truncated CHMP3, an ESCRT3 component (Raiborg and Stenmark, 2009), blocked membrane budding [51], resulting in the mutant's accumulation in abnormally large vac- uolar structures that contained both early and late endosomal markers. Dominant negative CHMP3 collocated with claudin-1 and -2 and with ubiquitin. Because surface biotinylation indicated a reduction of cell surface claudin1, it was concluded that dominant negative CHMP3 impaired claudin-1 recycling. However, the ESCRT complex is thought to mediate primarily the budding of multivesicular body (MVB) intraluminal vesicules [106], the main source of lysosome-targeted cargo, rather than recycling tubules. Since the cell-surface biotin fraction was not separated from the rest of the cell lysate, it is conceivable that the abundance of recycled claudin-1 was overestimated. The interaction of CHMP3 with phosphatidylinositol $(3,5)$ phosphate $(\operatorname{Ptd} \operatorname{Ins}(3,5) \mathrm{P} 2)$, an endomembrane phospholipid, is essential for MVB genesis [252]. PtdIns(3,5)P2) and its precursor, PtdIns 5-P, are synthesized by phosphatidylinositol 3-phosphate 5-kinase (PIKfyve) [201]. Concordantly, perturbation of PIKfyve activity by the pharmacological inhibitor YM201636 demonstrated that constitutive recycling of claudin-1 in MDCK cells depends on PIKfyve [53], similar to its dependence on ESCRT [103]. Approximately 35 percent of total cell surface claudin-1 was endocytosed and recycled in its majority back to the PM in untreated MDCK cells. In contrast, administration of YM201636 resulted in the accumulation of all the claudin-1 population in large cytoplasmic clusters. Whereas claudin-2 responded to YM201636 like claudin-1, the trafficking of claudin- 4 was unaffected, suggesting that its rate of endocytosis is significantly lower than those of claudin- 1 and -2 . Collectively, these results indicate that endocytic trafficking pathways differ not only among tight junction protein families but also within the claudin family.

Though most of the data on claudin membrane trafficking addressed individual claudin species, their dynamics are interdependent. This is not surprising given the large number of claudin species and the abundance of several species in the same cell. Claudin-4 trafficking in quiescent HEK-293 cells depended on claudin-8, but not viceversa [90]. Normally both claudins traveled together in endocytic vesicles and both bound the scaffold protein multi (M)PDZ [102, 117]. However, when claudin-8 was knocked down by siRNA, claudin- 4 was sequestered to the ER and the Golgi apparatus. The intracellular dynamics and cell junction recruitment of claudins-2 and -4 in and MDCK cells differed from each other [243]. In confluent cells, both claudins were located mainly at the cell junctions and to a lesser extent in cytoplasmic vesicles. Both newly synthesized claudins originated in the Golgi apparatus, but claudin- 4 preceded claudin- 2 at the cell junctions. Conjugation of fluorophores that emitted at either 549 or $505 \mathrm{~nm}$ to 'old' or to newly synthesized claudins, respectively, revealed that 'old' claudins were removed from the cell junctions to endocytic vesicles. Part of these vesicles were destined to lysosomal digestion, as they collocated with LAMP2. Surprisingly, removal of the carboxy-terminus PDZ-binding motif of claudin-4, which is required for binding to the PDZ domains of ZO1 and ZO2 [99], slowed the rate but not the steady-state 
abundance of claudin-2 at the cell junctions. Apparently, the PDZ-binding motif facilitates but is not categorically required for claudin recruitment to cell junctions. The truncated claudin- 4 half-life was longer than that of WT claudin-4, likely because it was unable to bind the E3 uniquitin ligase ligand of numb-protein X (LNX)1. The removal of the PDZ-binding motif of claudin-2 probably did not abolish its binding to $\mathrm{ZO} 1$ or $\mathrm{ZO} 2$ because, unlike claudin- 1 and 4 , it harbors a tyrosine at position -6 that is required for the formation of a second $\mathrm{ZO}$ binding site [169]. This tyrosine, which is present in other eight claudins, may account for the overabundance of claudin-2 over claudins 1, 3, 4, and 7 at the cell junctions of MDCK cells [243].

\subsection{Degradation}

Endocytosed claudins, either constitutively or in response to external stimuli, undergo either lysosomal digestion or proteosomal degradation. In quiescent Henrietta Lax (HeLa) cervical carcinoma cells, claudin-5 was polyubiquinated on K199, K214, and K215 in the carboxyterminus cytoplasmic domain, though ubiquitination of K199 was sufficient for proteolysis of more than half of the cellular claudin-5 population [137]. Several claudins were ubiquitinated by LNX1, a protein that harbors 4 PDZ domains. The first PDZ domain of LNX1 bound the claudin-1 PDZ-binding motif in quiescent MDCK cells [227]. Overexpression of EGFP-fused LNX1 resulted in the removal of claudins 1,2 , and 4 from the cell junctions. EGFP-LNX1collocated in part at the cell junctions with ZO1, occludin, and E-cadherin, whereas it collocated with claudin- 2 in the cytoplasm, including in late endosomes and lysosomes. Apparently, LNX1 ubiquinates at the cell junctions only claudins. Since ubiquitination serves also as an endocytic signal and for targeting to the interior of MVBs (Mukhopadhyay and Riezman, 2007) LNX1 may have designated cell junction claudins for removal from the cell junctions by endocytosis, whereas it designated endocytosed claudins to lysosomal digestion. LNX2, which has the same domain structure as LNX1 and is close to fifty percent identical, binds the carboxyterminus of claudin-1 [264] and is likely, therefore, to function as its E3 ubiquitin ligase. Rather than LNX1 or 2, claudin-16 was ubiquinated by two PDZ domaincontaining RING finger protein (PDZRN)-3 [139]. Similar to LNX1, PDZRN3 likely bound claudin-16 via its PDZ-binding motif, induced its endocytosis from the cell junctions, and designated it to lysosomal digestion, as indicated by its collocation with the late endosome marker Rab7.

\section{OCCLUDIN}

Occludin is encoded by a single gene in humans. It is grouped into a 3-member proteins family named tight junction-associated MARVEL protein (TAMP), based on sharing a 130-residue MAL and related proteins for vesicle trafficking and membrane link (MARVEL) domain [190]. The MARVEL domain spans the four transmembrane domains, corresponding to residues 60-269 of human occludin. Similar to claudins, occludin is a tetraspan protein, but its size is substantially larger (522 amino acids,), primarily due to a larger carboxy-terminus domain that consists of 257 amino acids in humans (Fig. 2). Its cytoplasmic domain binds the Src homology 3 (SH3) and the guanylate kinase $(\mathrm{GuK})$ domains of $\mathrm{ZO} 1$ via its coiled-coil region $[123,159]$. Occludin is recruited to the tight junctions by claudin [66] and incorporated into the claudin strands in a punctate pattern [211].

\subsection{Endocytosis}

There is extensive similarity between the endocytic and recycling pathways of claudins and occludin. Like claudins, occludin underwent constitutive endocytosis in malignant MTD-1A mouse mammary epithelial cells [153] with a half-time of $15 \mathrm{~min}$ at steady state via either clathrin or caveolin [59]. Similar to claudin-1 and -4 , occludin collocated with the clathrin heavy chain and with the clathrin adaptor $\alpha$-adaptin in human colon carcinoma epithelial cells after calcium depletion [100]. Occludin endocytosis was blocked by inhibitors of clathrinmediated endocytosis [100, 153]. VEGF induced clathrindependent endocytosis and phosphorylation of S490 in the carboxy-terminus cytoplasmic domain of occludin in primary bovine retinal ECs [160]. The phosphorylation induced association of the E3 ligase Itch and prompted occludin poly-ubiquitination. Polyubiquitinated occludin bound epsin-1 epidermal growth factor receptor pathway substrate (EPS)-15, and hepatocyte growth factorregulated tyrosine kinase substrate (HRS). Both proteins harbor ubiquitin-interacting motifs and facilitate endocytosis of ubiquitinated cell-surface proteins (Hofmann and Falquet, 2001). Endocytosed occludin collocated with each of these proteins in cytoplasmic punctae. Rab5, an early endosome marker [32], also collocated with occludin in cytoplasmic punctae in a monolayer of wounded MDCK cells [58].

$\mathrm{TNF} \alpha$, the prototypic member of the tumor necrosis factor ligand superfamily, induced caveolin-1-mediated occludin endocytosis in vivo in mouse jejunal epithelial cells downstream of myosin light chain kinase (MLCK) activation [138]. TNF $\alpha$ induced caveolin-mediated endocytosis of occludin in Caco-2 and T84 human colon metastatic epithelial cells. The endocytosis required the carboxy-terminal 107 amino acids of the cytoplasmic tail of occludin [29], a region shared with and named after RNA polymerase II elongation factor ELL [211]. The ELL region afforded binding to ZO1 and occludin dimerization [123]. In its absence, truncated occludin remained at the lateral cell membrane despite $\mathrm{TNF} \alpha$ treatment. Further supporting the regulatory role of the ELL domain, its expression had a dominant-negative effect on the endocytosis of endogenous occludin. The ELL positively charged residues, in particular K433, were essential for ZO1 binding to occludin [29].

All three major tight junction transmembrane proteins, claudin, occludin, and JAM, underwent macropinocytosis in T84 cells treated by interferon (IFN)- $\gamma$ [240], a cytokine that disrupts the integrity of epithelial cell monolayers (Madara and Stafford, 1989). The internalized tight junction transmembrane proteins were recruited collectively 


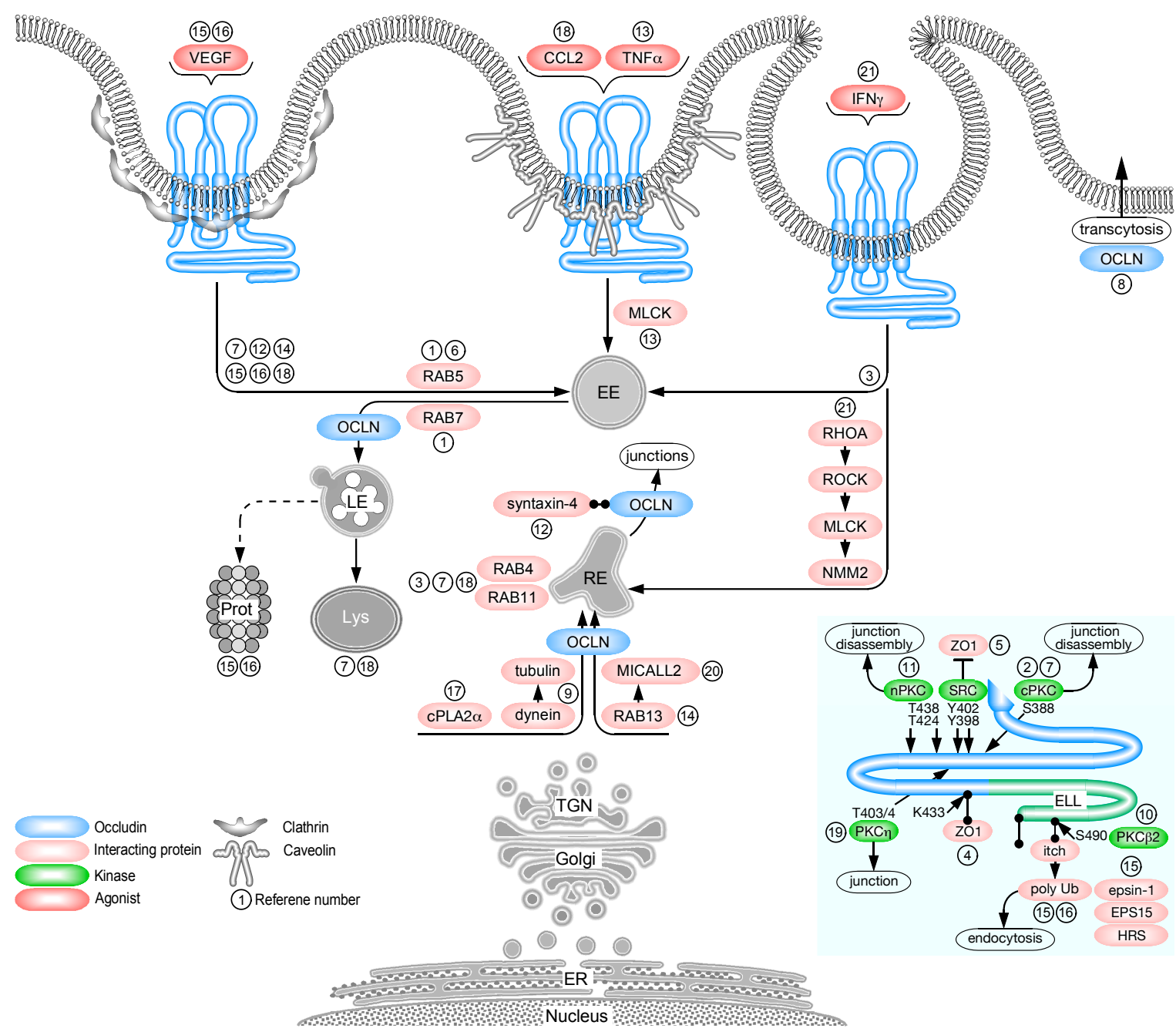

Figure 2: Scheme of membrane trafficking pathways of occludin. Inset shows phosphorylation sites and binding proteins of occludin's cytoplasmic domain. Dashed line indicates speculative feature. EE, early endosome; LE, late endosome; Lys, lysosome; MLCK, myosin light chain kinase, NMM2, non-muscle myosin 2; Prot, proteasome; RE, recycling endosome. Numbers correspond to the following references: (1) [5], (2) [6], (3) [23], (4) [29], (5) [56], (6) [58], (7) [59], (8) [71], (9) [75], (10) [82], (11) ([85], (12) [100], (13) [138], (14) [153], (15) [160], (16) [161], (17) [192], (18) [219], (19) [224], (20) [231], (21) $[240]$.

to subapical actin-coated vacuoles at a relatively slow rate, 38 hours after $\mathrm{IFN} \gamma$ treatment. IFN $\gamma$ initiated the formation of vacuoles by activating non-muscle myosin-2 via RhoA, Rho-associated kinase, and myosin light chain kinase. The vacuoles were identified as recycling endosomes by collocation with Rab4 and Rab11 [23]. Similar to claudin-5, occludin collocated cholera toxin, indicating it underwent caveolin/lipid raft-mediated endocytosis in CCL2-treated mouse brain primary ECs [219].

Similar to claudins, occludin is phosphorylated at multiple sites in the carboxy-terminus cytoplasmic domain. The phosphorylation effects on occludin endocytosis were site-specific. The most predominant occludin kinases were either 'conventional' $\mathrm{Ca}^{2+}$ and diacylglycerol (DAG)-dependent, or 'atypical' $\mathrm{Ca}^{2+}$ and DAG-independent PKCs. Because DAG induced tight junction assembly [12], the DAG analogs phorbol 12myristate 13-acetate and 1,2-dioctanoylglycerol were administered to MDCK cells to activate 'conventional' $\mathrm{Ca}^{2+}$ and DAG-dependent PKCs [6]. Under low calcium conditions, the treatment resulted in occludin recruitment to tight junctions and its phosphorylation. Conversely, treatment of $\mathrm{Ca}^{2+}$ replenished MDCK cells with the GF109203X PKC-specific pharmacological inhibitor [233] resulted in an opposite effect. The phosphorylation was attributed to a 'conventional' PKC because a mixture of $\mathrm{PKC} \alpha, \beta \mathrm{I}, \beta \mathrm{II}$, and $\gamma$ phosphorylated in vitro recombinant carboxy-terminus cytoplasmic domain of occludin. The site of phosphorylation was identified by mass spectroscopy as S388 in the carboxy terminus cytoplasmic domain of occludin. The involvement of 'atypical' $\mathrm{Ca}^{2+}$ and DAG-independent PKCs in the maintenance of epidermal barrier function [85] instigated investigation into the role of $\mathrm{PKC} \zeta$ in the regulation of $\mathrm{Caco}-2$ cell tight junctions. Treatment of quiescent cell monolayer with a myristoylated $\mathrm{PKC} \zeta$ pseudosubstrate disrupted the tight junctions and slowed junction assembly when the cells were subjected to a 'calcium switch', i.e., incubation in 
a calcium-chelating medium followed by replenishment with calcium-supplemented medium. $\mathrm{PKC} \zeta$ bound a 150 residue-long recombinant carboxy-terminus cytoplasmic domain of occludin in vitro. Threonine scanning of the cytoplasmic domain attributed the phosphorylation to T424 and T438.

Calcium replenishment-induced phosphorylation of Tyr398 and Tyr402 of human occludin expressed in MDCK cells and prevented its recruitment to cell junctions and its binding to ZO1 [56]. In vitro experiments suggested that Src was the likely kinase responsible for the phosphorylation. In contrast to the effects of the above phosphorylations, calcium replenishment-induced phosphorylation of the nearby T403/404 sites (determined by mass spectroscopy) induced occludin recruitment to the intercellular junctions of MDCK cells [224]. Occludin mutated on T403/404 to dephosphorylation-mimicking alanines was removed from the MDCK cell junctions upon calcium replenishment, whereas mutants harboring phosphorylation-mimicking replacements to aspartate were recruited to the junctions. Motivated by its conspicuous expression in epithelial cells [174], immunoblotting of occludin-precipitated cell lysate confirmed that $\mathrm{PKC} \eta$, a 'novel' diacylglycerol-dependent PKC, bound the carboxy-terminus cytoplasmic domain of occludin. Its pharmacological inhibition by a pseudo substrate peptide [170] and knockdown resulted in the disruption of the tight junctions of MDCK cells.

The effects of VEGF downstream signaling on intercellular junction proteins have been of obvious interest because the growth factor induces disassembly of intercellular junctions (Roberts and Palade, 1995). Since a phosphorylation cascade typically ensues downstream of tyrosine kinase receptors, numerous studies probed the extent of the phosphorylation of intercellular junction transmembrane proteins. Several early studies detected VEGFinduced phosphorylation of occludin in primary bovine retinal ECs [7] and determined that it existed in five to seven phosphorylated forms, suggesting the presence of multiple phosphorylation sites that were at least in part the substrates of 'conventional' PKC $\beta 2$ [82]. Mass spectroscopy analysis of VEGF-treated bovine retinal ECs detected phosphorylation of S490 [223]. VEGF increased occludin abundance in the cytoplasm at the expense of its presence along the cell borders. PKC $\beta 1$, an ATPcompetitive $\mathrm{PKC} \beta$-specific inhibitor, reversed the VEGFinduced distribution of occludin, suggesting that it was triggered by S490 dephosphorylation [161].

\subsection{Recycling}

Like claudin, Rab13 played a major role in the constitutive recycling of occludin in quiescent malignant mouse mammary epithelial cells, as indicated by the expressing the dominant negative Rab13Q67L mutant in MTD-1A cells. Both occludin and claudins 1 and 4 collocated with the t-SNARE protein syntaxin-4 in T84 epithelial cells [100] and required the Rab13 effector MICALL2 to recycle back to the PM [231]. Whereas Rab13-dependent trafficking bypassed the canonic recycling markers Rab4 and Rab11 [153], occludin collocated with Rab4 in mouse brain primary ECs treated with CCL2 [219] and with both Rab GTPases in T84 cells treated with IFN $\gamma$ [23]. In quiescent serum-starved MDCK cells, a minority of the claudin population returned to the $\mathrm{PM}$ via recycling endosomes in a Rab11-dependent manner [59]. Furthermore, cPLA $2 \alpha$ regulated the trafficking of occludin between the Golgi apparatus and HUVEC junctions in the same manner as claudin-5: depletion or inhibition of cPLA2 $\alpha$ was accompanied by the removal of occludin from the cell junctions and its accumulation in the Golgi apparatus [192]. Possibly because of its role in the maintenance of the Golgi apparatus structure [142], partitioning defective protein 3 (Par-3) was required for the trafficking of occludin from the TGN to the junctions of $\mathrm{TNF} \alpha$-treated Caco-2 cells. In its absence, occludin accumulated in the TGN [268]. Occludin translocated from the TGN to the surface of quiescent Caco-2 or MDCK cells along microtubules in vesicles propelled by the minus-end-directed molecular motor dynein at an approximate velocity of 1.6 $\mu \mathrm{m} / \mathrm{s}$ [75]. The first 10 amino acids of the cytoplasmic domain, spanning Lys266 to Lys283, were sufficient for targeting occludin to the cell surface [120].

\subsection{Degradation}

Unlike claudins, ESCRT did not regulate the recycling and fate of occludin [52]. Though there is heterogeneity in the half lives of claudins [241], several studies concurred that the half-life of occludin is shorter than those of claudins, possibly by three-fold [191, 234]. Direct measurements of occludin and claudin-1 dynamics in quiescent MDCK cells by fluorescence recovery after photobleaching revealed an inverse relation between the two proteins: whereas 76 percent of the steady-state population of claudin- 1 was at the attached to the cell junctions, the size of the cytoplasmic unattached fraction of occludin under the same conditions was 71 percent [210].

The aforementioned ubiquitin ligase Itch bound the amino-terminus cytoplasmic domain of occludin in HEK293 and LLC-PK pig kidney epithelial cells [234]. Based on the effect of the MG-132 proteasome-specific inhibitor [197], occludin was determined to undergo proteasomal degradation. The VEGF-induced phosphorylation of occludin on S490 in bovine endothelial retinal cells discussed above was required for Itch binding to occludin, for occludin ubiquitination, and, subsequently, for its proteasomal degradation [160]. VEGF augmented an ongoing constitutive proteasomal degradation of occludin because a low basal level of degradation was detected in untreated cells. In serum starved MDCK cells, close to half of the cellular occludin population underwent constitutive endocytosis in an approximate half-time of $15 \mathrm{~min}$. The majority of the endocytosed occludin population was apparently degraded, as only 20 percent returned to the cell surface [59]. Based on collocation with neuropeptide-Y, a lysosomal marker [229], and bafilomycin-A1, a lysosomal inhibitor [266], occludin degradation was attributed to the lysosome. 


\section{JUNCTIONAL ADHESION MOLECULE (JAM)}

The best-known members of the JAM protein family are encoded by 3 genes, F11R, JAM2 and JAM3. JAM's are 298-310 amino acid-long single pass proteins of the immunoglobulin family (Fig. 3). Their cytoplasmic domains range in length from 39 to 48 amino-acids and harbor PDZ-binding motifs at their carboxy-termini that bind the scaffold protein ZO1 at intercellular junctions [55]. JAM-A forms homophilic trans-dimers [152], whereas JAM-B and JAM-C can form either homo- or heterophilic interactions [114]. The topology of the JAMs as single pass transmembrane proteins contrasts with the four-pass topology of both claudins and occludin. A substantial part of the relatively limited number of studies, compared to the latter two proteins, focused on virus entry (e.g., [256]), a phenomenon that is deliberately not addressed in this review. Consequently, knowledge of the membrane trafficking of the JAM proteins under physiological conditions is relatively scarce, particularly in regard to JAM-B and -C. Though multiple residues in the JAM cytoplasmic domain are phosphorylated by identified kinases [221], their phosphorylation has not been linked to membrane trafficking.

Several of the studies reviewed above analyzed multiple species of tight junction proteins including the JAMs. Similar to claudins- 1 and -4, JAM-A collocated with the clathrin heavy chain and $\alpha$-adaptin in T84 cells, indicating that they were all endocytosed via clathrin-coated vesicles [100]. Subsequently, JAM-A was recruited to early endosomes, followed by segregation into a cytoplasmic subapical compartment where it collocated with syntaxin-4, possibly in preparation of reincorporation in the PM upon restoration of intercellular junctions. Collectively, these observations imply that JAM-A shares the endocytic pathway of the other prominent tight junction proteins in response to calcium chelation of the medium. The same conclusion can be drawn in regard to the administration of IFN $\gamma$ to T84 cells, whereby both occludin and JAM-A underwent macropinocytosis [23, 240]. The internalized proteins subsequently collocated with markers of early endosomes and with Rab4 and -11, markers of 'fast' and 'slow' recycling, respectively [23]. Either calcium chelation or stimulation with $\mathrm{TNF} \alpha$ induced endocytosis of JAM-C in HUVECs [110]. Subsequently, it was observed in tubular extensions from membranous structures formed at the cell junctions, but the endocytic pathway was not identified. The recruitment of JAM-C to the cell junctions depended on its interaction with junctionproximal scaffold proteins (likely ZO1 or -2), as indicated by an increase in its presence near the Golgi apparatus at the expense of the cell junctions. JAM-A endocytosis in Sertoli cells, which generate the hemato-testicular barrier, was blocked by knockdown of the clathrin heavy chain [253].

The induction of macropinocytosis appears to be common to inflammatory agonists: lipopolysaccharide (LSP) and CCL2 also induced JAM-A macropinocytosis [220], but more recent studies revealed that under these conditions, JAM-A trafficking differed from claudin and occludin. The JAM-A population that translocated from the cell junctions and relocated to cytoplasmic punctae in immortalized mouse brain bEND.3 ECs was separate from internalized occludin and claudin-5, as well as from vascular endothelial (VE)-cadherin. JAM-A translocated from the cell junctions to the cytoplasm in 10-20 min and recycled back to the PM in 30-60 min, substantially faster than the 24-48-hour dynamics observed by previous studies $[23,240]$. As expected, internalized JAM-A collocated with and required the activity of the macropinocytic marker Rab34 [222]. Subsequently, endocytosed JAM-A collocated with Rab5 and Rab4, indicating it trafficked to early endosomes and recycled rapidly back [220]. JAM-A was not collocated with Rab7, suggesting that only a small fraction of its population underwent lysosomal degradation. Similar to the response of JAM-A to IFN $\gamma$, lipopolysaccharide (LPS) and CCL2induced macropinocytosis required the activities of RhoA and Rho-associated protein kinase (ROCK).

The dynamics of JAM-C in quiescent human microvascular ECs were dissimilar from JAM-A. In contrast to the latter, the majority (approximately 80 percent) of JAM$\mathrm{C}$ was in the cytoplasm [173]. The remaining 20 percent were distributed diffusely on the cell surface rather than sequestered at the cell junctions. VEGF stimulation increased the cell-surface associated JAM-C fraction to 60 percent in approximately one hour. A more recent study on JAM-C dynamics in quiescent HUVECs reported that two thirds of the cell-surface JAM-C fraction was removed from the cell junctions in two hours [110]. The cytoplasmic JAM-C was detected partially in early endosomes and in MVBs, indicating that it underwent lysosomal degradation. Mutation of all four lysines located in the JAM-C cytoplasmic domain to arginines, intended to abolish its ubiquitination, resulted in an increase in JAM-C abundance in early endosomes, coupled with its decrease in MVBs. Unlike wild type JAM-C, which was targeted by ubiquitination to MVBs and, subsequently, to lysosomes, the mutant did not associate with the E3 ligase Casitas B-lineage lymphoma (CBL). TGF4beta, another inflammatory cytokine, targeted JAM-A to lysosomes in mouse lung carcinoma cells [108].

\section{CADHERINS}

Cadherin membrane trafficking is better understood than any other junction transmembrane protein because it has been studied longer and produced a larger number of publications. Cadherins are the largest junction transmembrane protein family, consisting of 114 members (Colas-Algora and Millan, 2019). This review will focus on the most abundant (though not the only) cadherins in epithelial and in ECs: epithelial (E) and VEcadherin, respectively. E- and VE-cadherin are 882 and 784 amino acid-long single-pass transmembrane proteins. They harbor five modular immunoglobulin-like extracellular-cadherin domains and cytoplasmic domains of 151 and 163 amino acids, respectively (Fig. 4). Unlike 


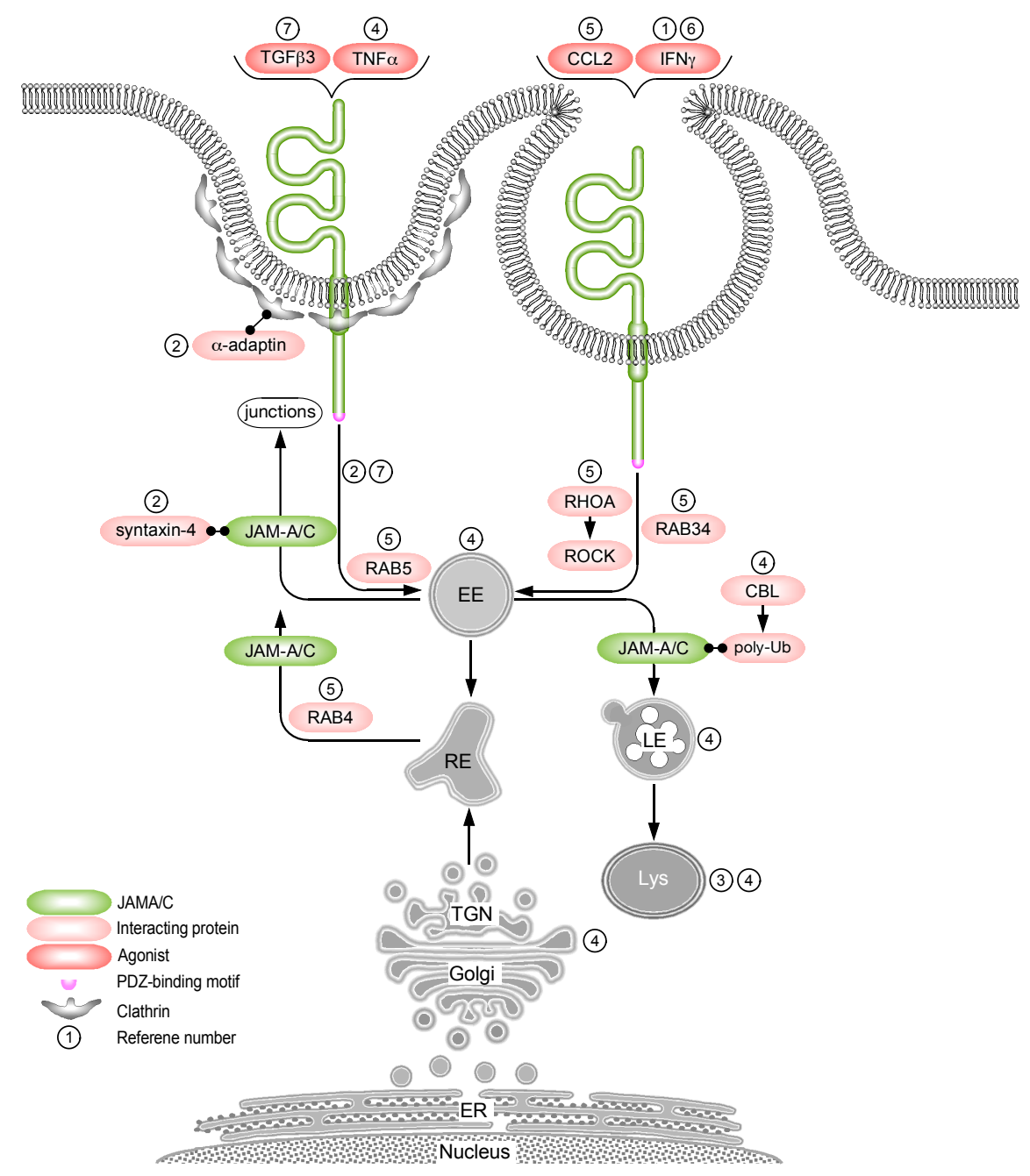

Figure 3: Scheme of membrane trafficking pathways of JAMs. EE, early endosome; LE, late endosome; Lys, lysosome; RE, recycling endosome. Numbers correspond to the following references: (1) [23], (2) [100], (3) [108], [110](4), (5) [219], (6) [240], (7) [253].

claudins, JAMs, and nectins, cadherins do not harbor a PDZ-binding motif and do not interact directly with PDZ domain-containing scaffold proteins. The canonical binding partners of their cytoplasmic domains are three members of the catenin protein family, $\alpha-, \beta$-, and $\alpha$-catenin (p120) [177]. $\beta$-catenin binds the carboxy-terminus region of the E-cadherin cytoplasmic domain (residues 811-882 of human E-cadherin) and to $\alpha$-catenin (Huber and Weis, 2001 ), whereas $\alpha$-catenin binds the juxtamembrane region of the E-cadherin cytoplasmic domain (residues 758769) [261]. $\alpha$-catenin crosslinks E-cadherin to f-actin under stretch [26]. VE-cadherin interacts with the three catenins in a similar manner [115].

\subsection{Endocytosis}

Similar to tight junction transmembrane proteins, Ecadherin underwent constitutive endocytosis, induced by transferring either MDCK cells [121], or MCF-7 epithelial breast cancer cells [181] from $18 \circ \mathrm{C}$ to $37 \circ \mathrm{C}$. Based on several lines of evidence, including the inhibitory effectiveness of $\mathrm{K}^{+}$depletion [119] and of bafilomycin A1 [105], the constitutive endocytosis in MDCK cells was construed to be clathrin-dependent. The presence of a YDSLL motif at position 827 of human E-cadherin cytoplasmic domain, known to recruit the host protein to clathrin-coated pits [235], further supported this premise [121]. In contrast, the E-cadherin constitutive endocytosis in MCF-7 cells was found to be clathrin-independent. Nevertheless, Ecadherin was detected in clathrin-coated pits by transmitted electron microscopy (EM), and, as the authors admitted, clathrin-dependent endocytosis may have occurred before the earliest sampled time point of $5 \mathrm{~min}$ post the $118 \circ \mathrm{C}$ to $37 \circ \mathrm{C}$ switch [181]. Constitutive endocytosis of VE-cadherin in human dermal microvascular ECs was not positively identified, but its attributes were consistent with clathrin-dependent endocytosis [254].

VE-cadherin in VEGF-treated HUVECs appeared in cytoplasmic vesicle as soon as 2 min after VEGF administration collocated with clathrin, dynamin-2, Rab5, and EEA1 (Gavard and Gutkind, 2006). The cytoplasmic domain VE-cadherin harbors a conserved region close to the $\delta$-catenin binding site that was phosphorylated by p21-activated kinase (PAK)-1 on S665 in a Src- 


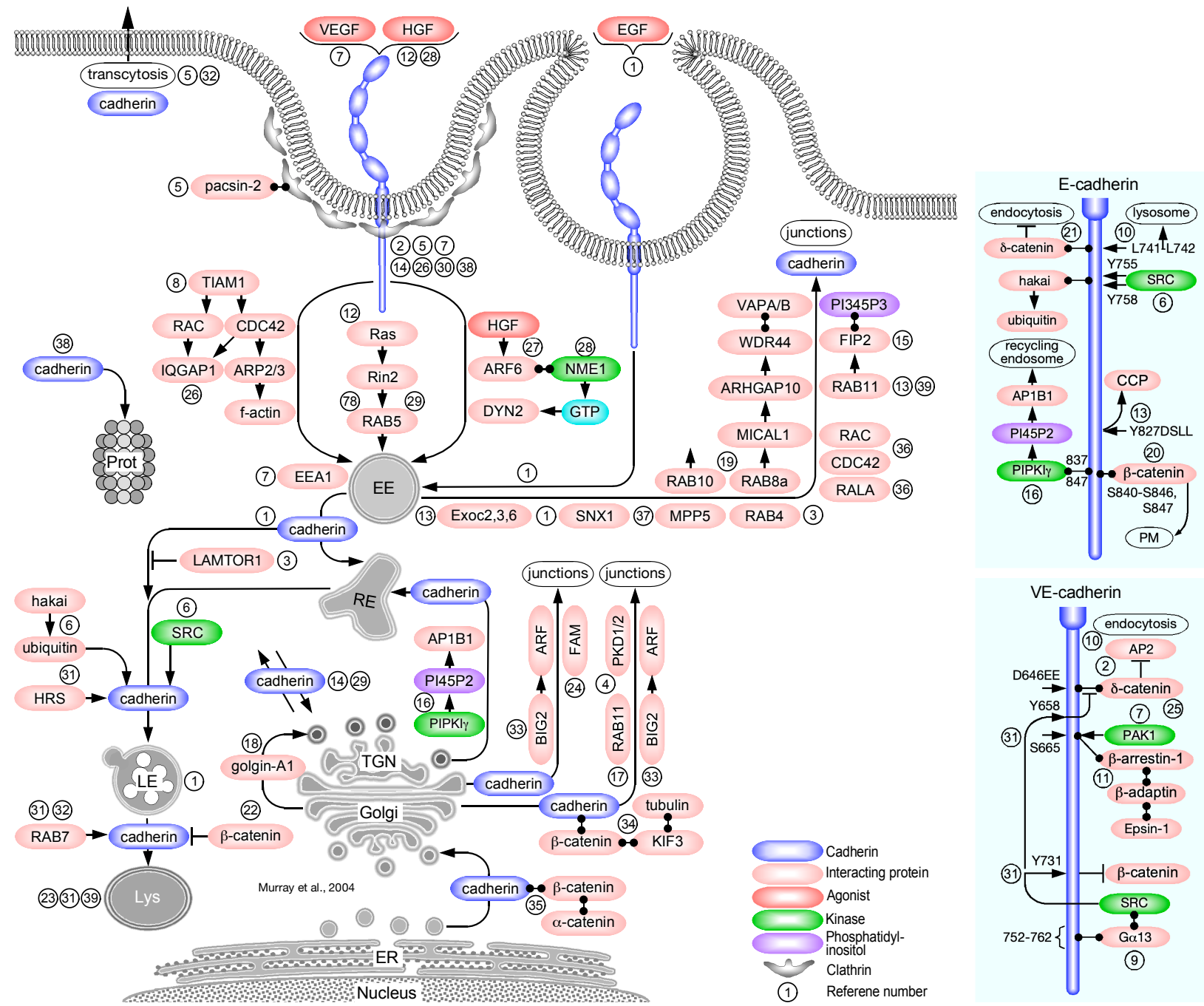

Figure 4: Scheme of membrane trafficking pathways of E- and VE-cadherin. Inset shows phosphorylation sites and binding proteins to the cytoplasmic domain of each cadherin. CCP, clathrin-coated pit; EE, early endosome; LE, late endosome; Lys, lysosome; Prot, proteasome; RE, recycling endosome. Numbers correspond to the following references: (1) [25], (2) [35], (3) [36], (4) [31], (5) [45], (6) [63], (7) [70], (8) [73], (9) [77], (10) [88], (11) [101], (12) [109], (13) [118], (14) [121], (15) [124], (16) [125], (17) [129], (18) [130], (19) [133], (20) [144], (21) [147], (22) [149], (23) [150], (24) [162], (25) [166], (26) [176], (27) [178], (28) [179], (29) [180], (30) [181], (31) [184], (32) [199], (33) [208], (34) [230], (35) [245], (36) [247], (37) [249], (38) [255], (39) [259].

dependent manner. The phosphorylation of this site was required and sufficient for VE-cadherin endocytosis. In contrast, a non-phosphorylatable S665V mutant remained at the cell junctions, whereas a S665D phosphomimic mutant was endocytosed constitutively in the absence of VEGF (Gavard and Gutkind, 2006). The phosphorylation of S665 likely recruited the clathrin-binding endocytic adapter arrestin- $\beta 1$, which bound and collocated with endocytosed VE-cadherin.

An insight into the relation between the homophilic trans interaction of cadherin ectoplasmic domains and endocytosis into their respective host cells was provided by coculturing A-431 human epidermal carcinoma epithelial cells that expressed E-cadherin with either a W213C or T227C mutation [236]. The positions of the cysteines permitted only the crosslinking of W213C-T227C transinteracting dimers E-cadherins after inducing dimeriza- tion by elevating $\mathrm{Ca}^{2+}$ concentration to $1 \mathrm{mM}$ and reducing their respective sulfhydryl groups [207] with the cysteine-specific crosslinker DPDPB [269]. The relation between E-cadherin binding in trans and its endocytosis was inspected by tracking the abundance of crosslinked heterodimers using immunoprecipitation and SDS-PAGE. ATP depletion by sodium azide and medium supplementation with sucrose to subject the cells to hypertonic shock, conditions known to inhibit endocytosis [87, 209] prevented intercellular junction disruption by calcium chelation or trypsin treatment, suggesting that endocytosis is the main mechanism of adhesive E-cadherin dissociation [236]. In contrast, f-actin disruption by cytochalasin D or latrunculin A, or reduction of myosin-generated tension by the ROCK inhibitor Y-27632 or the MLCK inhibitor ML-7 had only minor effects on the abundance of E-cadherin dimers or their formation rate. EM analy- 
sis showed that E-cadherin was internalized in endocytic vesicles from within the adherens junctions.

Observations made by two-photon fluorescence recovery after photobleaching (FRAP) and fast 3D fluorescence microscopy determined that only a small MDCK cell-surface E-cadherin fraction that did not exceed 10 percent of the total cellular population was free to diffuse laterally [43]. The majority of the population recycled between cell-surface E-cadherin bound in trans and cytoplasmic cadherin by endocytosis, with a junction residence time of $4 \mathrm{~min}$. Close to half of the cytoplasmic E-cadherin translocated from the PM within less than 3 min. In support of endocytosis as an exchange mechanism, both dynasore and myristyl trimethyl ammonium bromide (MiTMAB), a noncompetitive inhibitor of the GTPase activity of dynamin [188], suppressed E-cadherin exchange between the cytoplasmic and membrane populations. Subsequent studies measured the turnover of E-cadherin in quiescent A-431 cells by fusing its cytoplasmic domain to the green-to-red photoconvertible protein Dendra2 [88]. This technique distinguished between newly recruited E-cadherins fluorescing in green and red-fluorescing E-cadherins that dissociated from cell junctions post light-activated photoconversion. Junctionresiding E-cadherin molecules were replaced continuously with a half-time of approximately $2.5 \mathrm{~min}$. E-cadherin turnover at the cell junctions was apparently energydependent, because ATP depletion slowed it substantially.

The activity of the ADP-ribosylation factor (Arf)-6, a GTPase that regulates membrane trafficking between the PM and recycling endosomes [48], was essential for E-cadherin endocytosis. Expression of an Arf6 dominant negative mutant blocked hepatocyte growth factor (HGF)-induced internalization of E-cadherin downstream of Src [178]. A subsequent study determined that Arf6 was required for dynamin activation [179]. Yeast-twohybrid screen of Arf6-binding proteins identified nucleoside diphosphate kinase A (NME1), which synthesizes the GTP that drives dynamin activity [239]. E-cadherin endocytosis in MDCK cells entailed the recruitment of NME1 to GTP-Arf6 [179] and sequestration of the Rac1 guanine exchange factor (GEF) TIAM1 [176]. The ensuing reduction of Rac1 activity at the cell junctions presumably facilitated the inward translocation of endocytosed vesicles. The expression of dominant negative dynamin 2-K44A hindered E-cadherin endocytosis. Because E-cadherin did not collocate with caveolin, its endocytosis was apparently clathrin-dependent. Induction of vesicle budding in an adherens junction-enriched fraction of rat liver cells, followed by $\beta$-catenin vesicle immunoisolation, revealed that E-cadherin co-sedimented with the clathrin heavy chain, epsin-1, and the clathrin-coated vesicle component $\alpha$-adaptin (AP2B1) (Brodsky [22, 101]. Further establishing the dependence of E-cadherin endocytosis on clathrin, expression of the epsin N-terminal homology (ENTH) domain, which inhibits clathrin-dependent endocytosis of the EGF and insulin receptors [164], blocked either HGF or low calcium-induced E-cadherin endocytosis in MDCK cells [101]. A chimera consisting of the
E-cadherin ectoplasmic domain and the Fc region of human IgG expressed in mouse fibroblasts was endocytosed under low $\left(2 \mu \mathrm{M} \mathrm{Ca}^{2+}\right)$ but not under high $\left(2 \mathrm{mM} \mathrm{Ca}^{2+}\right)$, indicating that only non-trans-interacting E-cadherin on the surface of adjoining cells was endocytosed, in agreement with Troyanovksy et al. [236]. Trans-bound Ecadherin induced the activation of the Rho GTPases Rac and Cdc42 [101]. In turn, active Rac and Cdc42 inhibited E-cadherin endocytosis, presumably by the f-actin cross linking activity of their effector IQGAP1 $[15,113]$. In agreement, f-actin depolymerization by latrunculin-A augmented E-cadherin endocytosis.

E-cadherin endocytosis was linked to another adherens junction transmembrane protein, nectin. The endocytosis of non-cross-interacting E-cadherin expressed in the aforementioned mouse fibroblasts [101] was reduced significantly when these cells were transfected by full-length nectin-1, but not by nectin-1 devoid of the four aminoacid PDZ-binding domain at the carboxy terminus of its cytoplasmic domain [89], presumably because it was unable to bind afadin. While the expression of fulllength afadin in fibroblasts expressing E-cadherin and nectin-1 did not inhibit E-cadherin endocytosis, the expression of afadin lacking the amino-terminus domain reduced endocytosis, apparently because that domain sequesters Rap1[89]. The role of Rap1 in E-cadherin endocytosis was deduced to be the stabilization of E-cadherin binding to $\delta$-catenin, because co-expression of constitutively active Rap1 with E-cadherin and nectin-1 increased the abundance of E-cadherin-coimmunoprecipitated $\delta$ catenin compared to cells that expressed nectin- 1 devoid of the PDZ-binding domain. The Rap1-mediated stabilization mechanism was not specified.

The incorporation of epithelial cell surface proteins that harbor a dileucine motif, including E-cadherin, into clathrin-coated vesicles requires interaction with the AP1 complex subunit $\beta 1$ (AP1B1) [60]. Type I $\gamma$ phosphatidylinositol phosphate kinase (PIPKI $\gamma$ ) synthesizes phosphatidylinositol $(4,5)$ phosphate $\left(\operatorname{PtdIns}(4,5) \mathrm{P}_{2}\right)$, a phosphoinositol that facilitates the assembly of coat protein complexes [38]. PIPKI $\gamma$ associated preferentially with dimeric E-cadherin in MDCK cells, as well as with VE-cadherin in HUVECs and with neuronal (N)-cadherin in HEK-293 cells [125]. The E-cadherin binding region was narrowed down to amino-acids $837-847$ in its cytoplasmic domain, a motif conserved in VE- and Ncadherin. Interference with PIPKI $\gamma$ activity by either knockdown or expression of a kinase dead mutant resulted in depletion of E-cadherin from the cell junctions and its accumulation in cytoplasmic vesicles. In addition to its enzymatic activity, PIPKI $\gamma$ recruited E-cadherin to endocytic vesicles by binding to subunit $\beta 1$ of the AP1 complex. Replacement of the dileucine motif of E-cadherin in MCDK cells (L744-L745, corresponding to L741-L742 in human E-cadherin) with alanines reduced substantially E-cadherin endocytosis in cells transferred from $4 \circ \mathrm{C}$ to $37 \circ \mathrm{C}$ [149]. Whereas knockdown of $\delta$-catenin increased the endocytosis of wild type E-cadherin, it had no such effect on the leucine to alanine mutant. Apparently, both 
$\delta$-catenin dissociation and the presence of the dileucine motif are required for E-cadherin endocytosis.

More recent studies confirmed the role of both the dileucine motif and the presumably ubiquinated conserved K738 by mutating them to valine-alanine and to arginine, respectively [88]. Consequently, the constitutive endocytosis of the E-cadherin mutant in quiescent A-431 cells was practically blocked. Surprisingly, the mutation had no effect on E-cadherin turnover at the cell junctions, indicating that endocytosis cannot fully account for it. The turnover mechanism was not identified. Further analysis revealed that the binding of $\delta$-catenin to the cytoplasmic domain of E-cadherin and the interaction of the dileucine motif with clathrin adaptor complexes are not entirely independent of each other [98]. $\delta$ catenin binding involved two regions in the cytoplasmic domain, a 'static' motif spanning residues $747-781$, and 'dynamic' site that encompasses the dileucine endocytosis motif. The latter site was permissive to binding competition between $\delta$-catenin and clathrin adaptor complexes such as AP2, whose binding would initiate E-cadherin endocytosis. The interaction of E-cadherin with $\delta$-catenin was regulated also by the phosphorylation of the latter protein. MAPK1/3 (ERK)-mediated phosphorylation of T310 of $\delta$-catenin in MCF10A cells during wound closure abolished its binding to E-cadherin and released the latter from the cell surface [111]. Glycogen synthase kinase3 (GSK3)-mediated phosphorylation of the same residue dissociated $\delta$-catenin from $\mathrm{N}$-cadherin in astrocyte cells [182].

The association of E- or VE-cadherin with the endocytic machinery was mediated by their cytoplasmic domains. An internalized chimera consisting of the ectoplasmic and transmembrane domains of the interleukin (IL) 2 receptor (IL2R) and the cytoplasmic domain of VE-cadherin collocated extensively with endogenous VEcadherin in early endosomes when constitutive endocytosis was induced by transferring human dermal microvascular cells from $4 \circ \mathrm{C}$ to $37 \circ \mathrm{C}$ [254]. Cytosol acidification and $\mathrm{K}^{+}$depletion, approaches shown to inhibit clathrin endocytosis $[87,119]$, similarly inhibited the endocytosis of the IL2R-VE-cadherin chimera. The chimera internalized in 5 min after transference to $37^{\circ} \mathrm{C}$ and collocated with endocytosed transferrin, a marker of clathrin-dependent endocytosis [81]. Overexpression of $\delta$-catenin blocked internalization of IL2R-VE-cadherin, whereas replacing the EMD binding motif at position 652 of human VE-cadherin $[232]$ to alanines abolished $\delta$-catenin binding. The mutated VE-cadherin the former's collocated with clathrin and appeared in cytoplasmic punctae [255]. These results indicated that the clathrin-mediated endocytosis of VE-cadherin requires dissociation of $\delta$-catenin from its cytoplasmic domain. Once endocytosed, both $\delta$ - and $\beta$ catenin dissociated from VE-cadherin. Subsequent studies determined that $\delta$-catenin blocked VE-cadherin endocytosis by sequestering it away from membrane domains that were presumably populated by the clathrin-adaptor complex AP2 via an unknown mechanism [35]. In contrast to Xiao et al. [255], replacement of the EMD motif to ala- nines resulted only in a small reduction of the mutant's endocytosis in A-431 cells [166]. Rather, replacement of the DEE motif at position 646 of human VE-cadherin in the $\delta$-catenin-binding region abolished $\delta$-catenin binding almost completely. Apparently, $\delta$-catenin binding inhibited VE-cadherin endocytosis by masking the DEE motif.

E-cadherin endocytosis requires the activity of Rho GTPases and their effects on the actin cytoskeleton (Doherty and McMahon, 2009). Expression of a Cdc42 lossof-function (LOF) mutant in the epithelial cells of the Drosophila dorsal thorax resulted in a drastic reduction in the number of E-cadherin vesicular structures in the cytoplasm [73], and in the appearance of tubular endocytic vesicles associated with adherens junctions [122]. A LOF mutation in actin-related protein (Arp)-3, a subunit of the Arp2/3 complex and a Cdc42 effector [134], resulted in similar blockage of E-cadherin endocytosis [73]. LOF mutations of Par6 or of p21-activated kinase (Pak)1, both of which are Cdc42 effectors [19, 69], phenocopied the effect of Cdc42 LOF mutation on E-cadherin endocytosis [122].

In vitro experiments in HUVECs and in vivo experiments in zebrafish revealed that homophilic VE-cadherin trans dimers on adjacent cells underwent transcytosis while remaining bound to $\delta$-catenin [199]. The transcytosis required myosin-driven traction transmitted via $\mathrm{f}$ actin and Rac1 activity. The endocytic pathway was not specified, but none of the known pathways appeared to be involved. A contrasting phenomenon was observed in motile HUVECs when they formed transient focal adherenes junctions that anchored force bearing stress-fibers [93]. VE-cahderin located in these junctions was subjected to imbalanced tenstile forces that generates asymmetric junction geometry. Despite the asymmetry, only 9 percent of the VE-cadherin cellular population underwent transcytosis, whereas the majority was endocytosed into the host cell [45]. The endocytosis was apparently balanced out throug an unknown mechanism by recruitment of the BAR domain protein pacsin-2 to the curved PM around the focal adherens junction. Endocytosed VEcadherin was detected in Rab5 and Rab4-labeled vesicles, indicating that it recycled back to the PM through the 'fast' pathway.

Similar to tight junction transmembrane proteins, Ecadherin is internalized by macropinocytosis. The application of EGF to MCF-7 epithelial breast cancer cells resulted in the collocation of E-cadherin with $\delta$ and $\beta$ catenin in 2-2.25 $\mu \mathrm{m}$ macropinosomes that co-labeled with EEA1, followed by translocation to the juxtanuclear region [25]. Part of this population was in late endosomes and lysosomes, but its majority was recycled back to the cell surface. The recycling was mediated by sorting nexin (Snx)-1, an adaptor protein that mediates cargo selection by the retromer complex and retrograde trafficking to the TGN [27]. Given its involvement in early endosome to Golgi retrieval of proteins destined for degradation [76], association with Snx1 was expected to divert E-cadherin from degradation to recycling [25]. In agreement, Snx1 knockdown reduced substantially the extent of E-cadherin 
recycling to the cell surface.

E-cadherin endocytosis was associated with several types of posttranlational modifications. Viral Src expressed in MDCK cells phopshorylaetd Tyr755 and 758 in the cytoplasmic domain of E-cadherin [63]. The phosphorylation enabled binding of the E3 ligase Hakai and ubiquitination of E-cadherin, increasing the endocytosis of the latter in response to HGF. More recent studies [77] addressed the Src-mediated phosphorylation of Tyr658 of VE-cadherin in human dermal microvascular ECs, a modification known to dissociate $\delta$-catenin from VE-cadherin and facilitate its endocytosis [184]. Src was activated by the trimeric G $\alpha 13$ GTPase in HUVECs which bound both Src and residues 752-762 of the VE-cadherin cytoplasmic domain [77]. E-cadherin expressed in A-431 cells was constitutively phosphorylated on serines 840,846 and 847 in the $\beta$-catenin binding motif [77]. The phosphorylation facilitated $\beta$-catenin binding and favored recruitment of $\mathrm{E}$ cadherin to the PM. The kinase was not identified but was presumed to function in the Golgi apparatus. Contrary to the latter study, the phosphorylation of VE-cadherin on Tyr731 by Src in HUVECs prevented $\beta$-catenin binding, and, consequently, favored VE-cadherin endocytosis and lysosomal targeting [184] (see below).

Endocytosed E-cadherin in MDCK and MCF-7 cells and endocytosed VE-cadherin in human dermal microvascular ECs underwent Rab-mediated trafficking to early endosomes $[109,180]$. In response to HGF, Rab5 was activated by the GEF Ras and Rab interactor (RIN)-2 downstream of Ras [109]. N-cadherin expressed in immortalized rat fibroblasts collocated with $\delta$-catenin in cytoplasmic vesicles that translocated retrogradely at 0.5 $1.0 \mu \mathrm{m} / \mathrm{s}$ upon adherens junction disassembly induced by calcium chelation [34]. Vesicle movement was disrupted by nocodazole, indicating that they translocated along microtubules. The movement was driven by kinesin, recruited to the vesicles by $\mathrm{N}$-cadherin-bound $\delta$-catenin, which binds the kinesin heavy chain [260].

\subsection{Recycling}

Multiple studies identified the Golgi apparatus and the TGN as major destinations or departure points of cadherin during either constitutive recycling [121, 181], or as a result of the expression of dominant negative Rac1 [246]. Newly synthesized N-cadherin precursor expressed in HeLa cells was present in the ER and the Golgi apparatus prior to the cleavage of its signal peptide (residues 125) and propeptide (residues 26-159) [245]. The carboxyterminus of the Ncad precursor was phosphorylated and bound to $\delta$-catenin, after which the $\alpha$ and $\beta$ catenins bound to N-cadherin as a dimer. The stoichiometric ratios of $\mathrm{N}$-cadherin to the three catenins were close to unity, suggesting that most of the precursor $\mathrm{N}$-cadherin was bound to catenins before translocation from the ER and Golgi. Contrary to Wahl et al. [245], Miranda et al. ruled out systematically the presence of $\delta$-catenin in the ER and the Golgi apparatus of MDCK cells [147]. The disagreement was attributed to unspecified phenotypic differences between HeLa and MDCK cells. The transport of $\mathrm{N}$-cadherin from the Golgi apparatus to the periphery of mouse neural progenitor cells was driven by kinesin KIF3 [230], a microtubule plus end-directed anterograde molecular motor that associates with $\mathrm{N}$-cadherin via $\beta$-catenin [84]. Mutation of the dileucine motif at residues 741-742 of E-cadherin interfered with its routing to the basolateral membrane of MDCK cells, showing that the association with $\delta$-catenin was required for correct targeting of $\mathrm{E}$ cadherin [147]. This conclusion was challenged by a subsequent study, which found that E-cadherin mutants that lacked the whole cytoplasmic domain, or whose leucines were substituted by alanines, were detected exclusively on the PM of MDCK cells (Miyashita and Ozawa, 2007b). Instead of the basolateral membrane, the latter study concluded that the dileucine motif targeted E-cadherin to lysosomes [150] (see below). No explanation was provided to reconcile the disagreement between the conclusions of Miranda et al. and Miyashita and Ozawa in regard to the role of the dileucine motif in E-cadherin basolateral targeting.

Newly synthesized wild type E-cadherin, or a truncated mutant devoid of the dileucine motif expressed in the HeLa cells, translocated constitutively from the TGN via tubular or spherical endosomes that moved at an approximate rate of $3 \mu \mathrm{m} / \mathrm{s}$ [130]. In a minority of cases, the vesicles reached the cell periphery in $40 \mathrm{~s}$. After remaining stationary for $10 \mathrm{~s}$, the vesicles disappeared, possibly after fusion with the PM. The initial membrane trafficking of E-cadherin away from the Golgi apparatus was shared with occludin and claudin-5 [204]. The exit from the TGN was mediated by golgin-A1, a protein that binds directly to the TGN membrane [130]. Golgin-A1 was required up to but not after E-cadherin-associated vesicle budding from the TGN. The recruitment of E-cadherin to the PM in MDCK cells required the activities of Rac1 and Cdc42 [246]. Expression of dominant negative mutants of the two GTPases resulted in the accumulation of E-cadherin in large perinuclear vesicles that collocated poorly with Golgi and TGN markers. RalA, a GTPase that is component of the exocyst and is required for its structural stability [155], enhanced the delivery of E-cadherin-containing vesicles from the TGN to the PM [247]. Ubiquinated Ecadherin that would be normally destined to lysosomal degradation [107] was diverted in subcobfluent T84 epithelial cells to recycling together with $\beta$-catenin by the deubiquitinase fat facets in mammals (FAM) [162]. FAM collocated with both proteins in either the Golgi apparatus or in cytoplasmic vesicles that were possibly headed to the plasma membrane. Because FAM interacted with E-cadherin and $\beta$-catenin only in subconfluent cells, this mechanism is apparently inactive once cell junctions are stabilized.

Observations on epithelial proximal tubule cells from individuals carrying autosomal dominant polycystic kidney disease caused by LOF mutations in PKD1 and PKD2 revealed that E-cadherin was sequestered in perinuclear vesicles and was absent from cell junctions [31]. The mutant genes encode polycystins 1 and 2, large 11-pass trasmembrane proteins that are present in adherens junctions [202] and bind E-cadherin [21]. The nature of the 
vesicles and the manner by which polycistins facilitate the recruitment of E-cadherin to cell junctions are unknown. Another mechanism that favored E-cadherin recycling over degrdation was attributed to late endosomal/lysosomal adaptor and MAPK and MTOR activator (LAMTOR)-1 (named alternatively lipid raft adaptor protein p18), a protein that binds endosomal outer membranes and suppresses trafficking to lysosomes [163]. When rat lung microvascular ECs were challenged by LPS, overexpression of LAMTOR1 suppressed the typical removal of E-cadherin from the cell junctions and decreased its abundance in late endosomes in favor of early endosomes [36].

The involvement of Rab GTPases in cadherin membrane trafficking is known in more detail than for any other junction transmembrane protein. E-cadherin that underwent constitutive endocytosis in MCF-7 cells collocated with Rab11, a marker of 'slow' recycling, and relocated back to the cell surface in 15-30 min [181]. The majority of the above mentioned vesicular E-cadherin expressed in HeLa cells [130] trafficked in Rab11-associated recycling endosomes, from which they moved to and fused with the PM. The expression of a dominant negative Rab11 mutant In MDCK cells resulted in mistargeting of E-cadherin which translocated to the apical instead of to the basolateral region [44]. The recycling of VE-cadherin in human lung microvascular ECs required specifically the activity of Rab11a [259]. VE-cadherin endocytosed in response to calcium chelation collocated with Rab11a in cytoplasmic vesicles. Depletion of Rab11a blocked VEcadherin recycling back to the $\mathrm{PM}$, resulting in its accumulation in lysosomes. VE-cadherin and Rab11a associated with each other by forming a ternary complex with Rab11 family-interacting protein (FIP)-2, a Rab11 effector that binds PtdIns $(3,4,5) \mathrm{P}_{3}$ and targets recycling vesicles to the PM (Lindsay and McCaffrey, 2004). In accordance with the similarity between the endocytic mechanisms from the PM and the Golgi apparatus, the trafficking of E-cadherin from the TGN to recycling endosome required the activity of PIPKI $\gamma$ [125]. The inhibition of brefeldin A-inhibited GEF (BIG)-2, an Arf GEF citepRN487, blocked the trafficking of E-cadherin and $\beta$-catenin from the TGN to the adherens junctions of MDCK cells [208]. The potential role of Arf GTPases in this leg of E-cadherin trafficking would be to target recycling vesicles to the plasma membrane [48].

The trafficking of E-cadherin from recycling endosomes to the PM of MDCK cells depended on Rab8 in combination with MICALL2 [258], a Rab8 and Rab13 effector involved in the recycling of tight junction transmembrane proteins [153]. MICALL2 mediates membrane trafficking by regulating the assembly state of f-actin [198]. A recent study found that GTP-bound Rab8a and Rab10 were recruited to elongated E-cadherin-containing tubular vesicles in the perinuclear region of HeLa cells [133], followed by the recruitment of MICAL1, an actin filament-severing protein [92] and a likely Rab8 effector [189]. In turn, MICAL1 recruited the Rho GTPase-activating protein 10 (ARHGAP10), a BAR domain containing protein, which extends and stabilizes tubular vesicles. ARHGAP10 recruited WD repeat-containing protein 44 (WDR44), a scaffold protein that bridges elongating tubules with the endoplasmic reticulum (ER) by binding to the vesicleassociated membrane protein-associated proteins $\mathrm{A}$ and B (VAPA/B) [13]. This mode of exocytosis suggests that E-cadherin segregated in the ER from other cargo proteins [133].

The trafficking of E-cadherin in Drosophila epithelial cells from recycling endosomes to adherens junctions was mediated by the exocyst ectomeric complex. LOF of the genes encoding the Exoc2, Exoc3, and Exoc6 subunits, which are required for vesicle tethering to the PM (Whyte and Munro, 2002), resulted in the accumulation of VE-cadherin, of $\alpha$ and of $\beta$-catenin in enlarged Rab11marked recycling endosomes [118]. E-cadherin shares with claudins the same syntaxin-4-dependent mechanism of docking to the PM described above [100]. E-cadherin delivery to the PM of MDCK cells required an apicobasal complex protein, protein Associated with lin seven (PALS1)-1 (MPP5). In its absence, E-cadherin accumulated in cytoplasmic punctae adjacent to the cell periphery that did not collocate with early or recycling endosomes, or with Golgi markers [249]. The accumulation was caused probably by mislocation of the exocyst, as indicated by the absence of Exoc4 from the cell junctions.

\subsection{Degradation}

Inhibition of the proteasome by MG-132 blocked VEcadherin constitutive endocytosis in dermal microvascular ECs altogether, whereas inhibition of lysosome activity by chloroquine resulted in the accumulation of VEcadherin in cytoplasmic punctae [254]. These results suggested that both degradative pathways were involved in the processing of VE-cadherin, albeit at different stages of endocytosis.

Temperature-dependent overexpression of constitutively active Src in MDCK cells increased substantially at the permissive temperature the preexisting basal abundance of E-cadherin lysosomal digestion products [180]. E-cadherin was shown to be a Src substrate, suggesting that its tyrosine phosphorylation induced ubiquitination, possibly by the Hakai ligase [63], followed by targeting to lysosomes. The lysosomal sorting was mediated by the endocytic scaffold protein HRS, which collocated with E-cadherin in cytoplasmic vesicles and in LAMP1-associated endosomes. The switch to permissive temperature enhanced Rab7 activity, whereas the expression of dominant-negative Rab7 blocked E-cadherin lysosomal degradation, in agreement with the established role of Rab7 in trafficking to lysosomes [30]. The dependence of E-cadherin targeting to the lysosome on Rab7 was shared by VE-cadherin undergoing constitutive endocytosis in HUVECs [199].

Aside from its role in regulating cadherin endocytosis, the dileucine motif was implicated in the targeting of cadherin to the lysosome (Miyashita and Ozawa, 2007a). This conclusion stemmed from observations that replacement of the leucines with alanines resulted in the recruitment of E-cadherin to the basolateral membrane 
of MDCK cells and its absence from the lysosome, unlike wild-type E-cadherin. Dileucine motif sorting of Ecadherin required $\beta$-catenin binding to the cadherin cytoplasmic domain (Miyashita and Ozawa, 2007a), though the binding region of the latter is almost 70 amino acids downstream of the motif. E-cadherin mutants that lost the ability to bind $\beta$-catenin translocated through the biosynthetic pathway and reached early endosomes, but instead of undergoing exocytosis to the PM, they were diverted to lysosomes [150]. It was hypothesized that $\beta$ catenin binding to E-cadherin blocked the dileucine motif, thus preventing E-cadherin recruitment to lysosomes.

\section{NECTINS}

The nectin family consists of four single pass junction transmembrane proteins ranging in size from 510 to 549 amino acids [136] (Fig. 5). Nectins 1-3 are expressed ubiquitously, whereas nectin- 4 is specific to the placenta [195]. Nectins form cis-homodimers and either homophilic or heterophilic trans dimers via their extracellular domains, which contain three IgG-like loops [151]. The nectin cytoplasmic domains, which vary between 41 to 140 amino acids, harbor a carboxy-terminus PDZ-binding motif that conforms to the E/A-X-Y-V (X - any amino acid) consensus sequence. All nectins bind the PDZ domain of the adaptor protein Afadin, which cross links them to f-actin [226]. Nectin is the first junction transmembrane protein recruited to the PM during the formation of intercellular junctions [11]. Nectin-bound afadin recruits $\alpha$-catenin, followed by cadherin [225]. Nectin initiates the formation of tight junctions through the binding of $\mathrm{ZO} 1$ to the PDZ domain of afadin [54], which crosslinks nectins by dimerization [148]. Afadin's role in bridging adherens and tight junctions is addressed in section 7 below.

Figure 5: Scheme of membrane trafficking pathways of nectins. EE, early endosome; LE, late endosome; Lys, lysosome; Prot, proteasome; RE, recycling endosome. Numbers correspond to the following references: (1) (Dudak et al., 2011), (2) (Fujito et al., 2005), (3) (Generous et al., 2019), (4) (Guerrera et al., 2016), (5) (Kurita et al., 2013), (6) (Rehm et al., 2013), (7) (Young et al., 2012).

The trafficking pathway of nectin is least known among junction transmembrane proteins. Nectin was initially identified as a poliovirus receptor [145] and means of entry [74] into epithelial human cells. Studies on nectinmediated virus entry indicated that clustered nectin underwent phagocytosis [37] or lipid raft-mediated endocytosis [74]. These mechanisms differ from the clathrindependent endocytosis of nectin observed during cell junction remodeling among mouse embryo NIH 3T3 fibroblasts [64], they will not be addressed. Nectin is present in Sertoli cells and was shown to play an important role in spermatogenesis [20]. Though it does not function in these cells solely as an intercellular junction protein, it may employ the same endocytic pathway as in epithelial or endothelial cells. The endocytosis of nectin- 2 in Sertoli cells was characterized as clathrin-dependent because its degradation was blocked by shRNA-mediated clathrin knockdown (Zhang and Lui, 2014). Nectin-1bound nectin- 4 on the surface of adjoining A-431 cells underwent transcytosis into the nectin-1-expressing host cell [72]. The dominance of nectin- 1 in the pulling contest with nectin- 4 arose was attribute to its stronger anchoring to the cytoskeleton relative to nectin- 4 . The endocytosed nectin-1-nectin-4 complex apparently escaped degradation because it was not collocated with LAMP1. Instead, the complex collocated with vacuolar protein sorting-associated protein (VPS) 35, a subunit of the retromer, a trimeric complex that mediates tubulation and sorts cargo proteins for delivery either to the PM or the TGN [28].

Similar to endocytosis, nectin recycling is poorly known. The recruitment of nectin- 1 to the junctions of transformed monkey kidney fibroblasts (COS-7) depended on its binding to MAGUK p55 protein (MPP)3 [49], a scaffold protein that binds nectin- 1 and -3 via its single PDZ domain. The exclusion of nectin- 2 indicates that this interaction is highly specific: the last four carboxy-terminus amino-acids of both human and mouse nectin- 1 and -3 are identical, but they share only the last two amino-acids with nectin-2. Consequently, MPP3 was not required for cell junction recruitment of nectin-2. In contrast, MPP5, which has a similar domain structure to MPP3, including a single PDZ domain, recruited all three nectins, albeit with lower efficacy for nectin-1 [49]. It is unknown how binding to the afadin PDZ domain, the canonical nectin scaffold protein at the cell junctions [226], is reconciled with MPP3 and MPP5 binding to the nectin carboxy-terminus. Studies on Sertoli cells observed colocation of nectin-2 with Rab5a and Rab11a, indicating it reached early endosome and underwent 'slow' recycling to the cells' adhesive junctions [267].

An additional layer of complexity is added to the recruitment of nectin to cell junctions by the actin [10] and afadin-binding [193] scaffold protein drebrin. Knockdown of drebrin caused loss of nectin- 2 and -3 at the junctions of HUVECs. The binding of drebrin to afadin, mediated by their respective poly-proline regions, was required for nectin stabilization at the junctions. This was indicated by the increased presence of nectin- 2 in early endosomes and in lysosomes upon drebrin knockdown. The stabilization of nectin- 2 at the cell junctions required the formation of a nectin-afadin-drebrin complex. Afadin is the component of another trimeric complex consisting of PDZ domain-containing protein (PDZD)-11, a small single PDZ domain protein, and pleckstrin homology domain-containing family A member (PLEKHA)-7 which binds afadin and $\delta$-catenin directly [112]. The interactions of PDZZ11 with the PDZ-binding motif of nectins 1 and 3 and with PLEKHA7 stabilize adherens junctions by crosslinking nectin to cadherin via PLEKHA7 [78]. Similar to drebrin, either PDZD11 or PLEKHA7 knockdown caused partial loss of nectin- 1 and -3 from MDCK cell junctions. The loss was prevented by administration of MG-132, implying that nectin was degraded by the proteasome, in addition to the lysosome. PLEKHA7 recruited PDZD11 to cell junctions by binding its first 44 

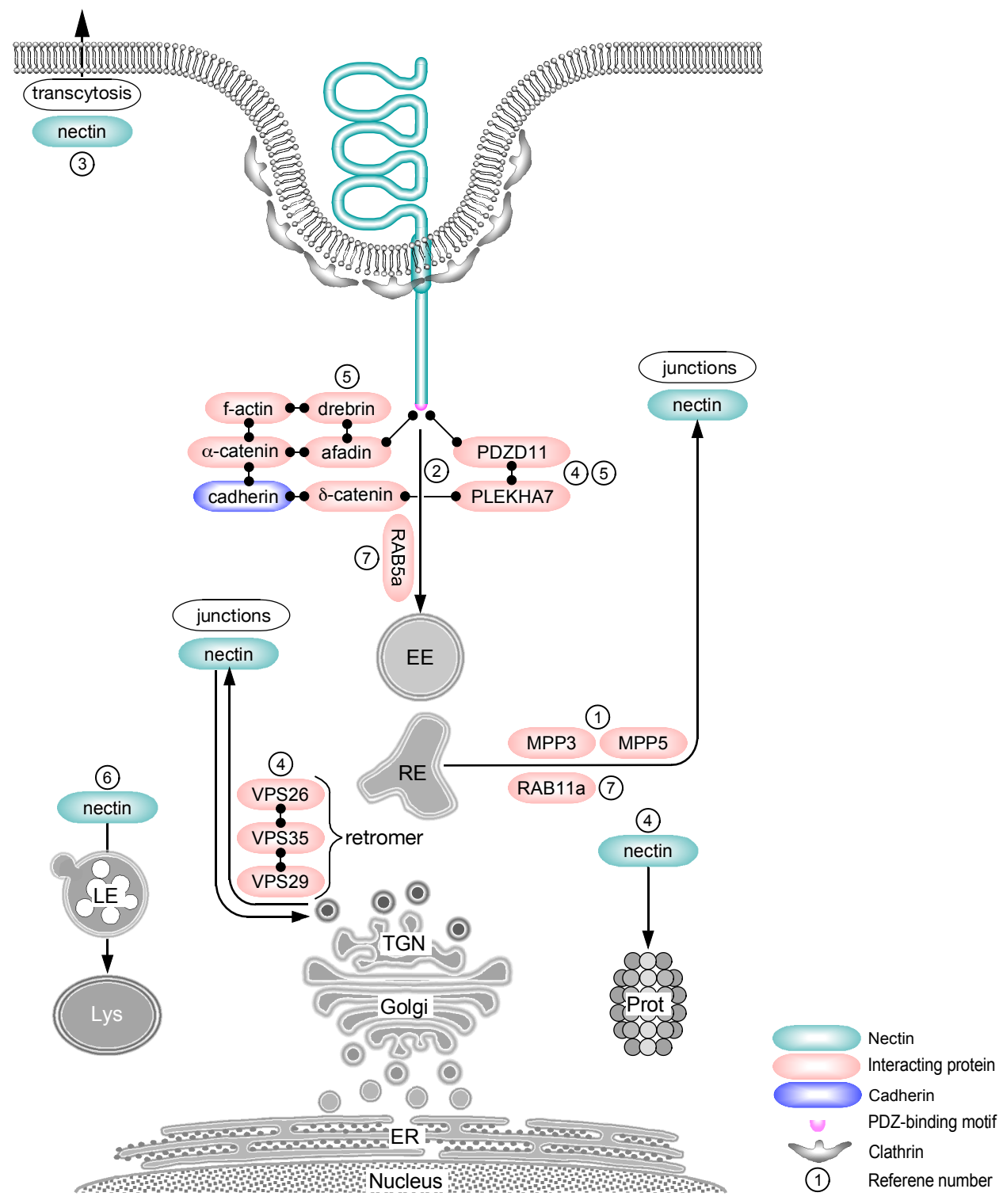

Figure 5: Scheme of membrane trafficking pathways of nectins. EE, early endosome; LE, late endosome; Lys, lysosome; Prot, proteasome; RE, recycling endosome. Numbers correspond to the following references: (1) [49], (2) [64], (3) $[72],(4)[78],(5)[112],(6)[193],(7)[267]$.

amino-terminus residues to its first WW domain. The PDZ domain of PDZD11 bound directly to the carboxyterminus of nectin-1 and -3 [78], thus stabilizing their attachment to cell junctions.

The studies reviewed above highlight the exceptionally large number of PDZ domain-containing proteins that nectins bind. In addition to afadin, all nectins bind PKC $\alpha$-binding protein (PICK)1 [196], MPDZ 'multiPDZ protein (MUPP)-1 (named alternatively MPDZ), and pals1-associated tight junction protein (PATJ) [1]. Nectin-1 and -3 bind also MPP3, MPP5, PDZD11, and PAR3 [228]. Though the functional specificity associated with each nectin binding-partner is unclear, their relatively large number and variety suggest that nectin has versatile context-dependent roles in the regulation of intercellular junctions and other cellular functions.

\section{DISCUSSION}

7.1 Interaction versus separation among endocytic pathways. Similar to other proteins [91]., 2012), occludin and E-cadherin contain putative sorting motifs in their carboxy-terminus cytoplasmic domains [100], but their function has not been confirmed. There appears to be specific assignation of Rab8a and Rab13 to adherens or tight junction protein recycling, respectively [258]. Their mutual effector, MICALL2, is shared, however, by both protein species. It is unknown how the junction-type specificity is conferred on Rab8a and Rab13.

Possibly the most prominent and best understood link between adherens and tight junction proteins is mediated by the adaptor protein afadin. Once bound to nectin, which is the first transmembrane protein recruited to cell junctions, it recruits ZO1 [265] via the binding of 
its proline-rich motifs to the SH3 domain of ZO1 [172]. Afadin-bound ZO1 recruits JAMA [65] and claudins, initiating their polymerization into strands [238]. Conversely, ZO1/2 facilitate adherens junction assembly [175] by participating in the generation of a structurally supportive circumferential f-actin bundle along the cell junctions [97].

Within adherens junctions, the endocytosis of Ecadherin is regulated by nectin. Nectin-bound afadin recruits the GTPase Rap1 [18], inducing the binding of $\delta$-catenin to afadin, and, concomitantly, recruiting Ecadherin. When bound in trans to nectin on adjoining cells, nectin blocked E-cadherin endocytosis in its host cell [89].

7.2 Fate decision. Despite having been published more than ten ago $[24,262]$, the insightful discussions of potential fate 'decision' mechanisms of integral cell junction proteins are largely relevant today because there has been relatively little progress in understanding these mechanisms. The earliest fate-determining step of cadherin appears to be Src-mediated phosphorylation, followed by ubiquitination, sorting by HRS, and Rab7-dependent trafficking to lysosomes, as described above [180]. The endosome outer membrane-binding protein and Rag GEF LAMTOR1 was reported to favor the recycling of Ecadherin from early endosomes to the plasma membrane over trafficking to late endosomes [36]. It was not specified, however whether it achieved this effect by activating Rag, or via another mechanism. A different early endosome-associated sorting activity was attributed to the retromer adaptor proteins Snx1, which diverted Ecadherin from degradation to recycling to the PM [25]. Other studies observed diversion of E-cadherin from lysosomal degradation to recycling and recruitment to cell junctions following deubiquitination in the Golgi apparatus by FAM [162] or activation of the Arf GTPase by the GEF BIG2 in the TGN [208], resulting in E-cadherin recyling to the plasma membrane [48].

7.3 Implications of liquid-liquid phase separation. Recent studies demonstrated that the scaffold protein ZO1 drives the generation of tight junctions while forming cytoplasmic condensates in live MDCK cells [17]. The formation of such condensates by ZO1 and potentially by other junction-associated scaffold proteins, e.g., MPDZ or inactivation-no-after-potential D like (INADL) [83] is a novel aspect of intercellular junction dynamics that is providing new insights into the underlying molecular mechanisms. The PM, ER, and endosomes provide platforms for the formation of liquid-liquid phase-separated condensates and interact with them (Zhao and Zhang, 2020). The emerging mechanism of tight junction initiation consists of ZO1 transition into PM-bound condensate, partitioning claudin and occludin as well as the afadin and cingulin scaffold proteins and triggering claudin polymerization and strand formation [17].

7.4 Functional specificity of scaffold proteins. As elaborated above, the $\mathrm{ZO}$ protein family plays a major role in the recruitment of tight junction proteins as well as in the structural support of tight and adherens junction, whereas afadin plays a similar role in adherens junction assembly. ZO1/2 bind numerous claudins via their PDZ domains, whereas afadin binds the three nectins in the same manner. These, however, are not the only binding partners of the PDZ-binding motifs of claudins and nectins. The homologous large scaffold proteins INADL and MPDZ bind essentially the same junction transmembrane proteins and have been localized to the cell junctions, similar to ZO1/2 and afadin $[167,212]$. How then are the interactions of claudins and nectins with $\mathrm{ZO} 1 / 2$ and afadin, respectively, reconciled with their interactions with INADL/MPDZ? What are the specific functions of INADL/MPDZ? Are those functions linked to intercellular junction homeostasis similar to ZO1/2 and afadin? While these questions cannot be answered in full at this time, preliminary data from the author's lab show that MPDZ collocates with Rab11a in cytoplasmic punctae (Fig. 6A) and is present in the TGN of subconfluent ECs (Fig. 6B), suggesting that MPDZ recycles. In parallel, MPDZ collocates with claudin-5, a prominent claudin in ECs [154], along EC junctions and in cytoplasmic punctae (Fig. 6C), suggesting that MPDZ, and possibly PATJ, are involved in junction protein dynamics rather than in their stabilization at the junctions.

\section{References}

[1] M. Adachi, Y. Hamazaki, Y. Kobayashi, M. Itoh, S. Tsukita, M. Furuse, and S. Tsukita. Similar and distinct properties of mupp1 and patj, two homologous pdz domaincontaining tight-junction proteins. Mol Cell Biol, 29 (9):2372-89, 2009. ISSN 1098-5549 (Electronic) 02707306 (Linking). doi: 10.1128/MCB.01505-08. URL https://www.ncbi.nlm.nih.gov/pubmed/19255144.

[2] W. Ahmad, K. Shabbiri, B. Ijaz, S. Asad, M. T. Sarwar, S. Gull, H. Kausar, K. Fouzia, I. Shahid, and S. Hassan. Claudin-1 required for hcv virus entry has high potential for phosphorylation and o-glycosylation. $\mathrm{Vi}$ rol J, 8:229, 2011. ISSN 1743-422X (Electronic) 1743$422 \mathrm{X}$ (Linking). doi: 10.1186/1743-422X-8-229. URL https://www.ncbi.nlm.nih.gov/pubmed/21569618.

[3] M. N. Ajuebor, C. M. Hogaboam, T. Le, and M. G. Swain. C-c chemokine ligand $2 /$ monocyte chemoattractant protein1 directly inhibits nkt cell il-4 production and is hepatoprotective in $\mathrm{t}$ cell-mediated hepatitis in the mouse. $\mathrm{J} \mathrm{Im}$ munol, 170(10):5252-9, 2003. ISSN 0022-1767 (Print) 00221767 (Linking). doi: 10.4049/jimmunol.170.10.5252. URL https://www.ncbi.nlm.nih.gov/pubmed/12734374.

[4] D. R. Alessi, A. Cuenda, P. Cohen, D. T. Dudley, and A. R. Saltiel. $\mathrm{Pd} 098059$ is a specific inhibitor of the activation of mitogen-activated protein kinase kinase in vitro and in vivo. $J$ Biol Chem, 270(46):27489-94, 1995. ISSN 0021-9258 (Print) 0021-9258 (Linking). doi: 10.1074/jbc.270.46.27489. URL https://www.ncbi.nlm.nih.gov/pubmed/7499206.

[5] M. M. Alfajaro, E. H. Cho, D. S. Kim, J. Y. Kim, J. G. Park, M. Soliman, Y. B. Baek, C. H. Park, M. I. Kang, S. I. Park, and K. O. Cho. Early porcine sapovirus infection disrupts tight junctions and uses occludin as a coreceptor. J Virol, 93(4), 2019. ISSN 1098-5514 (Electronic) 0022-538X (Linking). doi: 10.1128/JVI.01773-18. URL https://www.ncbi.nlm.nih.gov/pubmed/30463963.

[6] A. Y. Andreeva, E. Krause, E. C. Muller, I. E. Blasig, and D. I. Utepbergenov. Protein kinase c regulates the phosphorylation and cellular localization of occludin. $J$ 

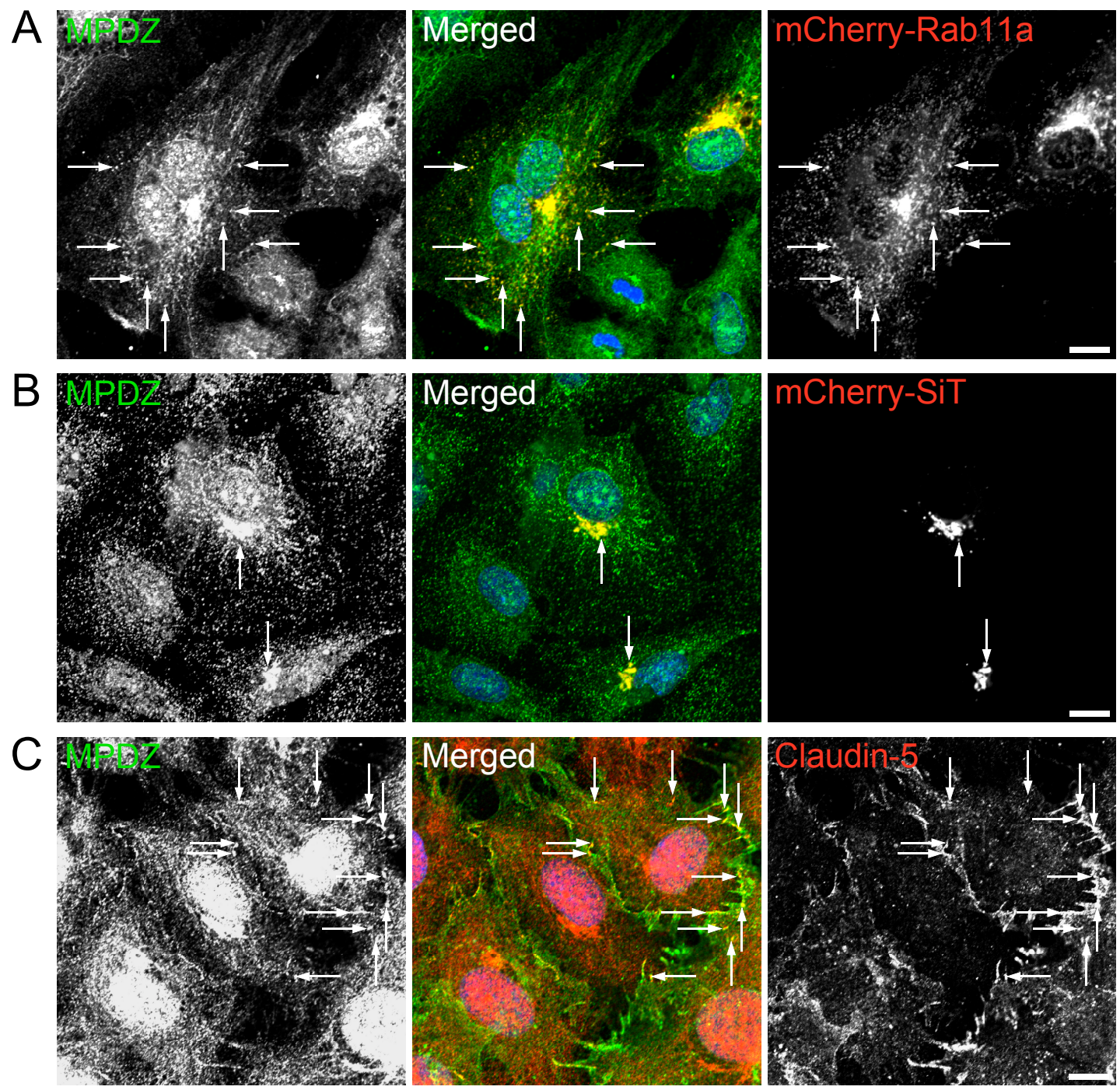

Figure 6: MPDZ collocates with vesicular Rab11 and the TGN, and with claudin-5. Subconfluent human dermal microvascular primary ECs were transduced by lentivirus expressing either Rab11a (A) or sialyltransferase (SiT) (B), a TGN marker (Dahdal and Colley, 1993) fused to mCherry, permeabilized by Triton X100, fixed by formaldehyde, and immunolabelled by antibody to MPDZ. Arrows point to cytoplasmic punctae of collocated MPDZ and Rab11 in A, or of collocated MPDZ and TGN marker in panel B. Note that MPDZ and Rab11a collocate also in the TGN. C. ECs permeabilized and fixed as above after 30 min of VEGF treatment were immunolabeled by antibodies to MPDZ and claudin-5. Arrows point to collocated MPDZ and claudin-5 along the cell junctions and in cytoplasmic punctae. Bars, $10 \mu \mathrm{m}$.

Biol Chem, 276(42):38480-6, 2001. ISSN 0021-9258 (Print) 0021-9258 (Linking). doi: 10.1074/jbc.M104923200. URL https://www.ncbi.nlm.nih.gov/pubmed/11502742.

[7] D. A. Antonetti, A. J. Barber, L. A. Hollinger, E. B. Wolpert, and T. W. Gardner. Vascular endothelial growth factor induces rapid phosphorylation of tight junction proteins occludin and zonula occluden 1. a potential mechanism for vascular permeability in diabetic retinopathy and tumors. $J$ Biol Chem, 274(33):23463-7, 1999. ISSN 0021-9258 (Print) 0021-9258 (Linking). doi: 10.1074/jbc.274.33.23463. URL https://www.ncbi.nlm.nih.gov/pubmed/10438525.

[8] S. Aono and Y. Hirai. Phosphorylation of claudin4 is required for tight junction formation in a human keratinocyte cell line. Exp Cell Res, 314(18): 3326-39, 2008. ISSN 1090-2422 (Electronic) 0014-4827 (Linking). doi: 10.1016/j.yexcr.2008.08.012. URL https://www.ncbi.nlm.nih.gov/pubmed/18786529.

[9] H. Arisawa, E. Imai, N. Fujise, K. Fukui, and H. Ma- sunaga. General pharmacological profile of the novel muscarinic receptor agonist sni-2011, a drug for xerostomia in sjogren's syndrome. 1st communication: effects on general behavior and central nervous system. Arzneimittelforschung, 52(1):14-20, 2002. ISSN 0004-4172 (Print) 0004-4172 (Linking). doi: 10.1055/s-0031-1299850. URL https://www.ncbi.nlm.nih.gov/pubmed/11838269.

[10] H. Asada, K. Uyemura, and T. Shirao. Actin-binding protein, drebrin, accumulates in submembranous regions in parallel with neuronal differentiation. $J$ Neurosci Res, 38(2):149-59, 1994. ISSN 0360-4012 (Print) 03604012 (Linking). doi: 10.1002/jnr.490380205. URL https://www.ncbi.nlm.nih.gov/pubmed/8078100.

[11] T. Asakura, H. Nakanishi, T. Sakisaka, K. Takahashi, K. Mandai, M. Nishimura, T. Sasaki, and Y. Takai. Similar and differential behaviour between the nectinafadin-ponsin and cadherin-catenin systems during the formation and disruption of the polarized junctional alignment in epithelial cells. Genes Cells, 4(10):573- 
81, 1999. ISSN 1356-9597 (Print) 1356-9597 (Linking). doi: 10.1046/j.1365-2443.1999.00283.x. URL https://www.ncbi.nlm.nih.gov/pubmed/10583506.

[12] M. S. Balda, L. Gonzalez-Mariscal, K. Matter, M. Cereijido, and J. M. Anderson. Assembly of the tight junction: the role of diacylglycerol. $J$ Cell Biol, 123(2):293-302, 1993. ISSN 0021-9525 (Print) 00219525 (Linking). doi: 10.1083/jcb.123.2.293. URL https://www.ncbi.nlm.nih.gov/pubmed/8408213.

[13] Y. Baron, P. G. Pedrioli, K. Tyagi, C. Johnson, N. T. Wood, D. Fountaine, M. Wightman, and G. Alexandru. Vapb/als 8 interacts with ffat-like proteins including the p97 cofactor faf1 and the asna1 atpase. BMC Biol, 12:39, 2014. ISSN 1741-7007 (Electronic) 1741-7007 (Linking). doi: 10.1186/1741-7007-1239. URL https://www.ncbi.nlm.nih.gov/pubmed/24885147.

[14] J. G. Barriocanal, J. S. Bonifacino, L. Yuan, and I. V. Sandoval. Biosynthesis, glycosylation, movement through the golgi system, and transport to lysosomes by an n-linked carbohydrate-independent mechanism of three lysosomal integral membrane proteins. J Biol Chem, 261(35):16755-63, 1986. ISSN 0021-9258 (Print) 0021-9258 (Linking). URL https://www.ncbi.nlm.nih.gov/pubmed/3782140.

[15] A. M. Bashour, A. T. Fullerton, M. J. Hart, and G. S. Bloom. Iqgap1, a rac- and cdc42-binding protein, directly binds and cross-links microfilaments. $J$ Cell Biol, 137(7):1555-66, 1997. ISSN 0021-9525 (Print) 0021-9525 (Linking). doi: 10.1083/jcb.137.7.1555. URL https://www.ncbi.nlm.nih.gov/pubmed/9199170.

[16] M. K. Bennett, J. E. Garcia-Arraras, L. A. Elferink, K. Peterson, A. M. Fleming, C. D. Hazuka, and R. H. Scheller. The syntaxin family of vesicular transport receptors. Cell, 74(5):863-73, 1993. ISSN 0092-8674 (Print) 00928674 (Linking). doi: 10.1016/0092-8674(93)90466-4. URL https://www.ncbi.nlm.nih.gov/pubmed/7690687.

[17] O. Beutel, R. Maraspini, K. Pombo-Garcia, C. MartinLemaitre, and A. Honigmann. Phase separation of zonula occludens proteins drives formation of tight junctions. Cell, 179(4):923-936 e11, 2019. ISSN 1097-4172 (Electronic) 0092-8674 (Linking). doi: 10.1016/j.cell.2019.10.011. URL https://www.ncbi.nlm.nih.gov/pubmed/31675499.

[18] B. Boettner, E. E. Govek, J. Cross, and L. Van Aelst. The junctional multidomain protein af- 6 is a binding partner of the rap1a gtpase and associates with the actin cytoskeletal regulator profilin. Proc Natl Acad Sci U S A, 97(16):9064-9, 2000. ISSN 0027-8424 (Print) 00278424 (Linking). doi: 10.1073/pnas.97.16.9064. URL https://www.ncbi.nlm.nih.gov/pubmed/10922060.

[19] G. M. Bokoch. Biology of the p21-activated kinases. Annu Rev Biochem, 72:743-81, 2003. ISSN 0066-4154 (Print) 0066-4154 (Linking). doi: 10.1146/annurev.biochem.72.121801.161742. URL https://www.ncbi.nlm.nih.gov/pubmed/12676796.

[20] M. J. Bouchard, Y. Dong, J. McDermott, B. M., D. H. Lam, K. R. Brown, M. Shelanski, A. R. Bellve, and V. R. Racaniello. Defects in nuclear and cytoskeletal morphology and mitochondrial localization in spermatozoa of mice lacking nectin-2, a component of cell-cell adherens junctions. Mol Cell Biol, 20(8):2865-73, 2000. ISSN 0270-7306 (Print) 02707306 (Linking). doi: $10.1128 / \mathrm{mcb} .20 .8 .2865-2873.2000$. URL https://www.ncbi.nlm.nih.gov/pubmed/10733589.

[21] C. A. Boucher, H. H. Ward, R. L. Case, K. S. Thurston, X. Li, A. Needham, E. Romero, D. Hyink, S. Qamar, T. Roitbak, S. Powell, C. Ward, P. D. Wilson, A. Wandinger-Ness, and R. N. Sandford. Receptor protein tyrosine phosphatases are novel components of a polycystin complex. Biochim Biophys Acta, 1812(10):1225-38, 2011. ISSN 0006-3002 (Print) 0006-3002 (Linking). doi: 10.1016/j.bbadis.2010.11.006. URL https://www.ncbi.nlm.nih.gov/pubmed/21126580.
[22] F. M. Brodsky, C. Y. Chen, C. Knuehl, M. C. Towler, and D. E. Wakeham. Biological basket weaving: formation and function of clathrin-coated vesicles. Annu Rev Cell Dev Biol, 17:517-68, 2001. ISSN 1081-0706 (Print) 10810706 (Linking). doi: 10.1146/annurev.cellbio.17.1.517. URL https://www.ncbi.nlm.nih.gov/pubmed/11687498.

[23] M. Bruewer, M. Utech, A. I. Ivanov, A. M. Hopkins, C. A. Parkos, and A. Nusrat. Interferon-gamma induces internalization of epithelial tight junction proteins via a macropinocytosis-like process. FASEB J, 19(8):923-33, 2005. ISSN 1530-6860 (Electronic) 08926638 (Linking). doi: 10.1096/fj.04-3260com. URL https://www.ncbi.nlm.nih.gov/pubmed/15923402.

[24] D. M. Bryant and J. L. Stow. The ins and outs of e-cadherin trafficking. Trends Cell Biol, 14(8): 427-34, 2004. ISSN 0962-8924 (Print) 0962-8924 (Linking). doi: 10.1016/j.tcb.2004.07.007. URL https://www.ncbi.nlm.nih.gov/pubmed/15308209.

[25] D. M. Bryant, M. C. Kerr, L. A. Hammond, S. R. Joseph, K. E. Mostov, R. D. Teasdale, and J. L. Stow. Egf induces macropinocytosis and snx1-modulated recycling of ecadherin. J Cell Sci, 120(Pt 10):1818-28, 2007. ISSN 00219533 (Print) 0021-9533 (Linking). doi: 10.1242/jcs.000653. URL https://www.ncbi.nlm.nih.gov/pubmed/17502486.

[26] C. D. Buckley, J. Tan, K. L. Anderson, D. Hanein, N. Volkmann, W. I. Weis, W. J. Nelson, and A. R. Dunn. Cell adhesion. the minimal cadherin-catenin complex binds to actin filaments under force. Science, 346 (6209):1254211, 2014. ISSN 1095-9203 (Electronic) 00368075 (Linking). doi: 10.1126/science.1254211. URL https://www.ncbi.nlm.nih.gov/pubmed/25359979.

[27] M. V. Bujny, V. Popoff, L. Johannes, and P. J. Cullen. The retromer component sorting nexin-1 is required for efficient retrograde transport of shiga toxin from early endosome to the trans golgi network. $J$ Cell Sci, 120(Pt 12):2010-21, 2007. ISSN 0021-9533 (Print) 0021-9533 (Linking). doi: 10.1242/jcs.003111. URL https://www.ncbi.nlm.nih.gov/pubmed/17550970.

[28] C. Burd and P. J. Cullen. Retromer: a master conductor of endosome sorting. Cold Spring Harb Perspect Biol, 6(2), 2014. ISSN 1943-0264 (Electronic) 19430264 (Linking). doi: 10.1101/cshperspect.a016774. URL https://www.ncbi.nlm.nih.gov/pubmed/24492709.

[29] M. M. Buschmann, L. Shen, H. Rajapakse, D. R. Raleigh, Y. Wang, Y. Wang, A. Lingaraju, J. Zha, E. Abbott, E. M. McAuley, L. A. Breskin, L. Wu, K. Anderson, J. R. Turner, and C. R. Weber. Occludin ocel-domain interactions are required for maintenance and regulation of the tight junction barrier to macromolecular flux. Mol Biol Cell, 24(19):3056-68, 2013. ISSN 1939-4586 (Electronic) 1059-1524 (Linking). doi: 10.1091/mbc.E12-09-0688. URL https://www.ncbi.nlm.nih.gov/pubmed/23924897.

[30] B. P. Ceresa and S. J. Bahr. rab7 activity affects epidermal growth factor:epidermal growth factor receptor degradation by regulating endocytic trafficking from the late endosome. $J$ Biol Chem, 281(2):1099-106, 2006. ISSN 0021-9258 (Print) 0021-9258 (Linking). doi: 10.1074/jbc.M504175200. URL https://www.ncbi.nlm.nih.gov/pubmed/16282324.

[31] A. J. Charron, S. Nakamura, R. Bacallao, and A. WandingerNess. Compromised cytoarchitecture and polarized trafficking in autosomal dominant polycystic kidney disease cells. $J$ Cell Biol, 149(1):111-24, 2000. ISSN 0021-9525 (Print) 0021-9525 (Linking). doi: 10.1083/jcb.149.1.111. URL https://www.ncbi.nlm.nih.gov/pubmed/10747091.

[32] P. Chavrier, R. G. Parton, H. P. Hauri, K. Simons, and M. Zerial. Localization of low molecular weight gtp 
binding proteins to exocytic and endocytic compartments. Cell, 62(2):317-29, 1990. ISSN 0092-8674 (Print) 00928674 (Linking). doi: 10.1016/0092-8674(90)90369-p. URL https://www.ncbi.nlm.nih.gov/pubmed/2115402.

[33] J. W. Chen, T. L. Murphy, M. C. Willingham, I. Pastan, and J. T. August. Identification of two lysosomal membrane glycoproteins. J Cell Biol, 101(1):85-95, 1985. ISSN 00219525 (Print) 0021-9525 (Linking). doi: 10.1083/jcb.101.1.85. URL https://www.ncbi.nlm.nih.gov/pubmed/2409098.

[34] X. Chen, S. Kojima, G. G. Borisy, and K. J. Green. p120 catenin associates with kinesin and facilitates the transport of cadherin-catenin complexes to intercellular junctions. $J$ Cell Biol, 163(3):547-57, 2003. ISSN 0021-9525 (Print) 0021-9525 (Linking). doi: 10.1083/jcb.200305137. URL https://www.ncbi.nlm.nih.gov/pubmed/14610057.

[35] C. M. Chiasson, K. B. Wittich, P. A. Vincent, V. Faundez, and A. P. Kowalczyk. p120-catenin inhibits ve-cadherin internalization through a rho-independent mechanism. Mol Biol Cell, 20(7):1970-80, 2009. ISSN 1939-4586 (Electronic) 1059-1524 (Linking). doi: 10.1091/mbc.E08-07-0735. URL https://www.ncbi.nlm.nih.gov/pubmed/19211843.

[36] H. Chichger, H. Duong, J. Braza, and E. O. Harrington. p18, a novel adaptor protein, regulates pulmonary endothelial barrier function via enhanced endocytic recycling of vecadherin. FASEB J, 29(3):868-81, 2015. ISSN 1530-6860 (Electronic) 0892-6638 (Linking). doi: 10.1096/fj.14-257212. URL https://www.ncbi.nlm.nih.gov/pubmed/25404710.

[37] C. Clement, V. Tiwari, P. M. Scanlan, T. Valyi-Nagy, B. Y. Yue, and D. Shukla. A novel role for phagocytosislike uptake in herpes simplex virus entry. $J$ Cell Biol, 174(7):1009-21, 2006. ISSN 0021-9525 (Print) 00219525 (Linking). doi: 10.1083/jcb.200509155. URL https://www.ncbi.nlm.nih.gov/pubmed/17000878.

[38] B. M. Collins, A. J. McCoy, H. M. Kent, P. R. Evans, and D. J. Owen. Molecular architecture and functional model of the endocytic ap2 complex. Cell, 109 (4):523-35, 2002. ISSN 0092-8674 (Print) 0092-8674 (Linking). doi: 10.1016/s0092-8674(02)00735-3. URL https://www.ncbi.nlm.nih.gov/pubmed/12086608.

[39] X. Cong, Y. Zhang, J. Li, M. Mei, C. Ding, R. L. Xiang, L. W. Zhang, Y. Wang, L. L. Wu, and G. Y. Yu. Claudin-4 is required for modulation of paracellular permeability by muscarinic acetylcholine receptor in epithelial cells. $J$ Cell Sci, 128(12):2271-86, 2015. ISSN 1477-9137 (Electronic) 0021-9533 (Linking). doi: 10.1242/jcs.165878. URL https://www.ncbi.nlm.nih.gov/pubmed/25948584.

[40] H. Damke, T. Baba, D. E. Warnock, and S. L. Schmid. Induction of mutant dynamin specifically blocks endocytic coated vesicle formation. $J$ Cell Biol, 127(4):915-34, 1994. ISSN 0021-9525 (Print) 00219525 (Linking). doi: 10.1083/jcb.127.4.915. URL https://www.ncbi.nlm.nih.gov/pubmed/7962076.

[41] E. Daro, P. van der Sluijs, T. Galli, and I. Mellman. Rab4 and cellubrevin define different early endosome populations on the pathway of transferrin receptor recycling. Proc Natl Acad Sci U S A, 93(18):9559-64, 1996. ISSN 0027-8424 (Print) 0027-8424 (Linking). doi: 10.1073/pnas.93.18.9559. URL https://www.ncbi.nlm.nih.gov/pubmed/8790369.

[42] M. A. Davis, R. C. Ireton, and A. B. Reynolds. A core function for p120-catenin in cadherin turnover. $J$ Cell Biol, 163(3):525-34, 2003. ISSN 0021-9525 (Print) 0021-9525 (Linking). doi: 10.1083/jcb.200307111. URL https://www.ncbi.nlm.nih.gov/pubmed/14610055.
[43] S. de Beco, C. Gueudry, F. Amblard, and S. Coscoy. Endocytosis is required for e-cadherin redistribution at mature adherens junctions. Proc Natl Acad Sci U $S$ A, 106(17):7010-5, 2009. ISSN 1091-6490 (Electronic) 00278424 (Linking). doi: 10.1073/pnas.0811253106. URL https://www.ncbi.nlm.nih.gov/pubmed/19372377.

[44] M. Desclozeaux, J. Venturato, F. G. Wylie, J. G. Kay, S. R. Joseph, H. T. Le, and J. L. Stow. Active rab11 and functional recycling endosome are required for e-cadherin trafficking and lumen formation during epithelial morphogenesis. Am J Physiol Cell Physiol, 295(2):C545-56, 2008. ISSN 0363-6143 (Print) 0363-6143 (Linking). doi: 10.1152/ajpcell.00097.2008. URL https://www.ncbi.nlm.nih.gov/pubmed/18579802.

[45] Y. L. Dorland, T. S. Malinova, A. M. van Stalborch, A. G. Grieve, D. van Geemen, N. S. Jansen, B. J. de Kreuk, K. Nawaz, J. Kole, D. Geerts, R. J. Musters, J. de Rooij, P. L. Hordijk, and S. Huveneers. The fbar protein pacsin2 inhibits asymmetric ve-cadherin internalization from tensile adherens junctions. Nat Commun, 7:12210, 2016. ISSN 2041-1723 (Electronic) 20411723 (Linking). doi: 10.1038/ncomms12210. URL https://www.ncbi.nlm.nih.gov/pubmed/27417273.

[46] T. D'Souza, R. Agarwal, and P. J. Morin. Phosphorylation of claudin-3 at threonine 192 by camp-dependent protein kinase regulates tight junction barrier function in ovarian cancer cells. J Biol Chem, 280(28):26233-40, 2005. ISSN 0021-9258 (Print) 0021-9258 (Linking). doi: 10.1074/jbc.M502003200. URL https://www.ncbi.nlm.nih.gov/pubmed/15905176.

[47] T. D'Souza, F. E. Indig, and P. J. Morin. Phosphorylation of claudin- 4 by pkcepsilon regulates tight junction barrier function in ovarian cancer cells. Exp Cell Res, 313(15):3364-75, 2007. ISSN 0014-4827 (Print) 00144827 (Linking). doi: 10.1016/j.yexcr.2007.06.026. URL https://www.ncbi.nlm.nih.gov/pubmed/17678893.

[48] C. D'Souza-Schorey, E. van Donselaar, V. W. Hsu, C. Yang, P. D. Stahl, and P. J. Peters. Arf6 targets recycling vesicles to the plasma membrane: insights from an ultrastructural investigation. J Cell Biol, 140(3):603-16, 1998. ISSN 00219525 (Print) 0021-9525 (Linking). doi: 10.1083/jcb.140.3.603. URL https://www.ncbi.nlm.nih.gov/pubmed/9456320.

[49] A. Dudak, J. Kim, B. Cheong, H. J. Federoff, and S. T. Lim. Membrane palmitoylated proteins regulate trafficking and processing of nectins. Eur J Cell Biol, 90(5):365-75, 2011. ISSN 1618-1298 (Electronic) 01719335 (Linking). doi: 10.1016/j.ejcb.2011.01.004. URL https://www.ncbi.nlm.nih.gov/pubmed/21371776.

[50] D. T. Dudley, L. Pang, S. J. Decker, A. J. Bridges, and A. R. Saltiel. A synthetic inhibitor of the mitogenactivated protein kinase cascade. Proc Natl Acad Sci $U S A, 92(17): 7686-9,1995$. ISSN 0027-8424 (Print) 0027-8424 (Linking). doi: 10.1073/pnas.92.17.7686. URL https://www.ncbi.nlm.nih.gov/pubmed/7644477.

[51] J. D. Dukes, J. D. Richardson, R. Simmons, and P. Whitley. A dominant-negative escrt-iii protein perturbs cytokinesis and trafficking to lysosomes. Biochem $J, \quad 411(2): 233-9, \quad 2008$. ISSN 1470-8728 (Electronic) 0264-6021 (Linking). doi: 10.1042/BJ20071296. URL https://www.ncbi.nlm.nih.gov/pubmed/18076377.

[52] J. D. Dukes, L. Fish, J. D. Richardson, E. Blaikley, S. Burns, C. J. Caunt, A. D. Chalmers, and P. Whitley. Functional escrt machinery is required for constitutive recycling of claudin1 and maintenance of polarity in vertebrate epithelial cells. Mol Biol Cell, 22(17):3192-205, 2011. ISSN 1939-4586 (Electronic) 1059-1524 (Linking). doi: 10.1091/mbc.E11-04-0343. URL https://www.ncbi.nlm.nih.gov/pubmed/21757541. 
[53] J. D. Dukes, P. Whitley, and A. D. Chalmers. The pikfyve inhibitor ym201636 blocks the continuous recycling of the tight junction proteins claudin- 1 and claudin-2 in mdck cells. PLoS One, 7(3):e28659, 2012. ISSN 1932-6203 (Electronic) 19326203 (Linking). doi: 10.1371/journal.pone.0028659. URL https://www.ncbi.nlm.nih.gov/pubmed/22396724.

[54] K. Ebnet, C. U. Schulz, M. K. Meyer Zu Brickwedde, G. G. Pendl, and D. Vestweber. Junctional adhesion molecule interacts with the pdz domain-containing proteins af- 6 and zo- $1 . J$ Biol Chem, 275(36):27979-88, 2000. ISSN 0021-9258 (Print) 0021-9258 (Linking). doi: 10.1074/jbc.M002363200. URL https://www.ncbi.nlm.nih.gov/pubmed/10856295.

[55] K. Ebnet, M. Aurrand-Lions, A. Kuhn, F. Kiefer, S. Butz, K. Zander, M. K. Meyer zu Brickwedde, A. Suzuki, B. A. Imhof, and D. Vestweber. The junctional adhesion molecule (jam) family members jam-2 and jam-3 associate with the cell polarity protein par-3: a possible role for jams in endothelial cell polarity. J Cell Sci, 116(Pt 19):3879-91, 2003. ISSN 00219533 (Print) 0021-9533 (Linking). doi: 10.1242/jcs.00704. URL https://www.ncbi.nlm.nih.gov/pubmed/12953056.

[56] B. C. Elias, T. Suzuki, A. Seth, F. Giorgianni, G. Kale, L. Shen, J. R. Turner, A. Naren, D. M. Desiderio, and R. Rao. Phosphorylation of tyr-398 and tyr-402 in occludin prevents its interaction with zo-1 and destabilizes its assembly at the tight junctions. $J$ Biol Chem, 284(3):1559-69, 2009. ISSN 0021-9258 (Print) 00219258 (Linking). doi: 10.1074/jbc.M804783200. URL https://www.ncbi.nlm.nih.gov/pubmed/19017651.

[57] P. A. Eyers, M. Craxton, N. Morrice, P. Cohen, and M. Goedert. Conversion of sb 203580-insensitive map kinase family members to drug-sensitive forms by a single amino-acid substitution. Chem Biol, 5(6):3218, 1998. ISSN 1074-5521 (Print) 1074-5521 (Linking). doi: 10.1016/s1074-5521(98)90170-3. URL https://www.ncbi.nlm.nih.gov/pubmed/9653550.

[58] S. J. Fletcher, N. S. Poulter, E. J. Haining, and J. Z. Rappoport. Clathrin-mediated endocytosis regulates occludin, and not focal adhesion, distribution during epithelial wound healing. Biol Cell, 104(4): 238-56, 2012. ISSN 1768-322X (Electronic) 02484900 (Linking). doi: 10.1111/boc.201100004. URL https://www.ncbi.nlm.nih.gov/pubmed/22187938.

[59] S. J. Fletcher, M. Iqbal, S. Jabbari, D. Stekel, and J. Z. Rappoport. Analysis of occludin trafficking, demonstrating continuous endocytosis, degradation, recycling and biosynthetic secretory trafficking. PLoS One, 9(11): e111176, 2014. ISSN 1932-6203 (Electronic) 1932-6203 (Linking). doi: 10.1371/journal.pone.0111176. URL https://www.ncbi.nlm.nih.gov/pubmed/25422932.

[60] H. Folsch, M. Pypaert, S. Maday, L. Pelletier, and I. Mellman. The ap-1a and ap-1b clathrin adaptor complexes define biochemically and functionally distinct membrane domains. J Cell Biol, 163(2):351-62, 2003. ISSN 0021-9525 (Print) 0021-9525 (Linking). doi: 10.1083/jcb.200309020. URL https://www.ncbi.nlm.nih.gov/pubmed/14581457.

[61] M. Fujibe, H. Chiba, T. Kojima, T. Soma, T. Wada, T. Yamashita, and N. Sawada. Thr203 of claudin-1, a putative phosphorylation site for map kinase, is required to promote the barrier function of tight junctions. Exp Cell Res, 295(1):36-47, 2004. ISSN 0014-4827 (Print) 00144827 (Linking). doi: 10.1016/j.yexcr.2003.12.014. URL https://www.ncbi.nlm.nih.gov/pubmed/15051488.

[62] N. Fujii, Y. Matsuo, T. Matsunaga, S. Endo, H. Sakai, M. Yamaguchi, Y. Yamazaki, J. Sugatani, and A. Ikari. Hypotonic stress-induced down-regulation of claudin-1 and -2 mediated by dephosphorylation and clathrin-dependent endocytosis in renal tubular epithelial cells. J Biol Chem,
291(47):24787-24799, 2016. ISSN 1083-351X (Electronic) 0021-9258 (Linking). doi: 10.1074/jbc.M116.728196. URL https://www.ncbi.nlm.nih.gov/pubmed/27733684.

[63] Y. Fujita, G. Krause, M. Scheffner, D. Zechner, H. E. Leddy, J. Behrens, T. Sommer, and W. Birchmeier. Hakai, a c-cbllike protein, ubiquitinates and induces endocytosis of the ecadherin complex. Nat Cell Biol, 4(3):222-31, 2002. ISSN 1465-7392 (Print) 1465-7392 (Linking). doi: 10.1038/ncb758. URL https://www.ncbi.nlm.nih.gov/pubmed/11836526.

[64] T. Fujito, W. Ikeda, S. Kakunaga, Y. Minami, M. Kajita, Y. Sakamoto, M. Monden, and Y. Takai. Inhibition of cell movement and proliferation by cell-cell contact-induced interaction of necl-5 with nectin-3. $J$ Cell Biol, 171(1):165-73, 2005. ISSN 0021-9525 (Print) 0021-9525 (Linking). doi: 10.1083/jcb.200501090. URL https://www.ncbi.nlm.nih.gov/pubmed/16216929.

[65] A. Fukuhara, K. Irie, H. Nakanishi, K. Takekuni, T. Kawakatsu, W. Ikeda, A. Yamada, T. Katata, T. Honda, T. Sato, K. Shimizu, H. Ozaki, H. Horiuchi, T. Kita, and Y. Takai. Involvement of nectin in the localization of junctional adhesion molecule at tight junctions. Oncogene, 21(50):7642-55, 2002. ISSN 0950-9232 (Print) 0950-9232 (Linking). doi: 10.1038/sj.onc.1205875. URL https://www.ncbi.nlm.nih.gov/pubmed/12400007.

[66] M. Furuse, K. Fujita, T. Hiiragi, K. Fujimoto, and S. Tsukita. Claudin-1 and -2: novel integral membrane proteins localizing at tight junctions with no sequence similarity to occludin. J Cell Biol, 141(7):1539-50, 1998. ISSN 0021-9525 (Print) 0021-9525 (Linking). doi: 10.1083/jcb.141.7.1539. URL https://www.ncbi.nlm.nih.gov/pubmed/9647647.

[67] M. Furuse, H. Sasaki, and S. Tsukita. Manner of interaction of heterogeneous claudin species within and between tight junction strands. J Cell Biol, 147(4):891-903, 1999. ISSN 00219525 (Print) 0021-9525 (Linking). doi: 10.1083/jcb.147.4.891. URL https://www.ncbi.nlm.nih.gov/pubmed/10562289.

[68] Y. Gao and W. Y. Lui. Transforming growth factorbeta1 (tgf-beta1) regulates cell junction restructuring via smad-mediated repression and clathrin-mediated endocytosis of nectin-like molecule 2 (necl-2). PLoS One, 8 (5):e64316, 2013. ISSN 1932-6203 (Electronic) 1932-6203 (Linking). doi: 10.1371/journal.pone.0064316. URL https://www.ncbi.nlm.nih.gov/pubmed/23741316.

[69] S. M. Garrard, C. T. Capaldo, L. Gao, M. K. Rosen, I. G. Macara, and D. R. Tomchick. Structure of cdc42 in a complex with the gtpase-binding domain of the cell polarity protein, par6. EMBO J, 22(5):1125-33, 2003. ISSN 0261-4189 (Print) 0261-4189 (Linking). doi: 10.1093/emboj/cdg110. URL https://www.ncbi.nlm.nih.gov/pubmed/12606577.

[70] J. Gavard and J. S. Gutkind. Vegf controls endothelialcell permeability by promoting the beta-arrestindependent endocytosis of ve-cadherin. Nat Cell Biol, 8(11):1223-34, 2006. ISSN 1465-7392 (Print) 1465-7392 (Linking). doi: 10.1038/ncb1486. URL http://www.ncbi.nlm.nih.gov/pubmed/17060906.

[71] N. Gehne, A. Lamik, M. Lehmann, R. F. Haseloff, A. V. Andjelkovic, and I. E. Blasig. Cross-over endocytosis of claudins is mediated by interactions via their extracellular loops. PLoS One, 12(8):e0182106, 2017. ISSN 1932-6203 (Electronic) 19326203 (Linking). doi: 10.1371/journal.pone.0182106. URL https://www.ncbi.nlm.nih.gov/pubmed/28813441.

[72] A. R. Generous, O. J. Harrison, R. B. Troyanovsky, M. Mateo, C. K. Navaratnarajah, R. C. Donohue, C. K. Pfaller, O. Alekhina, A. P. Sergeeva, I. Indra, T. Thornburg, I. Kochetkova, D. D. Billadeau, M. P. Taylor, S. M. Troyanovsky, B. Honig, L. Shapiro, and R. Cattaneo. Trans-endocytosis elicited by nectins transfers cytoplasmic cargo, including infectious material, between cells. 
J Cell Sci, 132(16), 2019. ISSN 1477-9137 (Electronic) 0021-9533 (Linking). doi: 10.1242/jcs.235507. URL https://www.ncbi.nlm.nih.gov/pubmed/31331966.

[73] M. Georgiou, E. Marinari, J. Burden, and B. Baum. Cdc42, par6, and apkc regulate arp2/3-mediated endocytosis to control local adherens junction stability. Curr Biol, 18(21):1631-8, 2008. ISSN 0960-9822 (Print) 09609822 (Linking). doi: 10.1016/j.cub.2008.09.029. URL https://www.ncbi.nlm.nih.gov/pubmed/18976918.

[74] R. J. Geraghty, C. Krummenacher, G. H. Cohen, R. J. Eisenberg, and P. G. Spear. Entry of alphaherpesviruses mediated by poliovirus receptor-related protein 1 and poliovirus receptor. Science, 280(5369): 1618-20, 1998. ISSN 0036-8075 (Print) 0036-8075 (Linking). doi: 10.1126/science.280.5369.1618. URL https://www.ncbi.nlm.nih.gov/pubmed/9616127.

[75] L. G. Glotfelty, A. Zahs, C. Iancu, L. Shen, and G. A. Hecht. Microtubules are required for efficient epithelial tight junction homeostasis and restoration. Am J Physiol Cell Physiol, 307(3):C245-54, 2014. ISSN 1522-1563 (Electronic) 0363-6143 (Linking). doi: 10.1152/ajpcell.00336.2013. URL https://www.ncbi.nlm.nih.gov/pubmed/24920678.

[76] S. Gokool, D. Tattersall, and M. N. Seaman. Ehd1 interacts with retromer to stabilize snx1 tubules and facilitate endosome-to-golgi retrieval. Traffic, 8(12):187386, 2007. ISSN 1398-9219 (Print) 1398-9219 (Linking). doi: 10.1111/j.1600-0854.2007.00652.x. URL https://www.ncbi.nlm.nih.gov/pubmed/17868075.

[77] H. Gong, X. Gao, S. Feng, M. R. Siddiqui, A. Garcia, M. G. Bonini, Y. Komarova, S. M. Vogel, D. Mehta, and A. B. Malik. Evidence of a common mechanism of disassembly of adherens junctions through galpha13 targeting of vecadherin. J Exp Med, 211(3):579-91, 2014. ISSN 1540-9538 (Electronic) 0022-1007 (Linking). doi: 10.1084/jem.20131190. URL https://www.ncbi.nlm.nih.gov/pubmed/24590762.

[78] D. Guerrera, J. Shah, E. Vasileva, S. Sluysmans, I. Mean, L. Jond, I. Poser, M. Mann, A. A. Hyman, and S. Citi. Plekha7 recruits pdzd11 to adherens junctions to stabilize nectins. J Biol Chem, 291(21): 11016-29, 2016. ISSN 1083-351X (Electronic) 00219258 (Linking). doi: 10.1074/jbc.M115.712935. URL https://www.ncbi.nlm.nih.gov/pubmed/27044745.

[79] D. Gunzel. Claudins: vital partners in transcellular and paracellular transport coupling. Pflugers Arch, 469(1):35-44, 2017. ISSN 1432-2013 (Electronic) 00316768 (Linking). doi: 10.1007/s00424-016-1909-3. URL https://www.ncbi.nlm.nih.gov/pubmed/27888337.

[80] S. J. Hagen. Non-canonical functions of claudin proteins: Beyond the regulation of cell-cell adhesions. Tissue Barriers, 5(2):e1327839, 2017. ISSN 2168-8370 (Electronic) 21688362 (Linking). doi: 10.1080/21688370.2017.1327839. URL https://www.ncbi.nlm.nih.gov/pubmed/28548895.

[81] J. A. Hanover, M. C. Willingham, and I. Pastan. Kinetics of transit of transferrin and epidermal growth factor through clathrin-coated membranes. Cell, 39(2 Pt 1):283-93, 1984. ISSN 0092-8674 (Print) 0092-8674 (Linking). doi: 10.1016/0092-8674(84)90006-0. URL https://www.ncbi.nlm.nih.gov/pubmed/6149810.

[82] N. S. Harhaj, E. A. Felinski, E. B. Wolpert, J. M. Sundstrom, T. W. Gardner, and D. A. Antonetti. Vegf activation of protein kinase c stimulates occludin phosphorylation and contributes to endothelial permeability. Invest Ophthalmol Vis Sci, 47(11):5106-15, 2006. ISSN 0146-0404 (Print) 0146-0404 (Linking). doi: 10.1167/iovs.06-0322. URL https://www.ncbi.nlm.nih.gov/pubmed/17065532.
[83] T. S. Harmon, A. S. Holehouse, M. K. Rosen, and R. V. Pappu. Intrinsically disordered linkers determine the interplay between phase separation and gelation in multivalent proteins. Elife, 6, 2017. ISSN 2050-084X (Electronic) 2050-084X (Linking). doi: 10.7554/eLife.30294. URL https://www.ncbi.nlm.nih.gov/pubmed/29091028.

[84] M. Y. Hein, N. C. Hubner, I. Poser, J. Cox, N. Nagaraj, Y. Toyoda, I. A. Gak, I. Weisswange, J. Mansfeld, F. Buchholz, A. A. Hyman, and M. Mann. A human interactome in three quantitative dimensions organized by stoichiometries and abundances. Cell, 163 (3):712-23, 2015. ISSN 1097-4172 (Electronic) 00928674 (Linking). doi: 10.1016/j.cell.2015.09.053. URL https://www.ncbi.nlm.nih.gov/pubmed/26496610.

[85] I. Helfrich, A. Schmitz, P. Zigrino, C. Michels, I. Haase, A. le Bivic, M. Leitges, and C. M. Niessen. Role of apkc isoforms and their binding partners par3 and par6 in epidermal barrier formation. J Invest Dermatol, 127(4):782-91, 2007. ISSN 1523-1747 (Electronic) 0022-202X (Linking). doi: 10.1038/sj.jid.5700621. URL https://www.ncbi.nlm.nih.gov/pubmed/17110935.

[86] S. P. Herbert, S. Ponnambalam, and J. H. Walker. Cytosolic phospholipase a2-alpha mediates endothelial cell proliferation and is inactivated by association with the golgi apparatus. Mol Biol Cell, 16(8):3800-9, 2005. ISSN 1059-1524 (Print) 1059-1524 (Linking). doi: 10.1091/mbc.e05-02-0164. URL https://www.ncbi.nlm.nih.gov/pubmed/15930125.

[87] J. Heuser. Effects of cytoplasmic acidification on clathrin lattice morphology. J Cell Biol, 108(2):401-11, 1989. ISSN 00219525 (Print) 0021-9525 (Linking). doi: 10.1083/jcb.108.2.401. URL https://www.ncbi.nlm.nih.gov/pubmed/2563729.

[88] S. Hong, R. B. Troyanovsky, and S. M. Troyanovsky. Spontaneous assembly and active disassembly balance adherens junction homeostasis. Proc Natl Acad Sci U S A, 107(8):3528-33, 2010. ISSN 1091-6490 (Electronic) 00278424 (Linking). doi: 10.1073/pnas.0911027107. URL https://www.ncbi.nlm.nih.gov/pubmed/20133579.

[89] T. Hoshino, T. Sakisaka, T. Baba, T. Yamada, T. Kimura, and Y. Takai. Regulation of e-cadherin endocytosis by nectin through afadin, rap1, and p120ctn. J Biol Chem, 280(25):24095-103, 2005. ISSN 0021-9258 (Print) 00219258 (Linking). doi: 10.1074/jbc.M414447200. URL https://www.ncbi.nlm.nih.gov/pubmed/15857834.

[90] J. Hou, A. Renigunta, J. Yang, and S. Waldegger. Claudin-4 forms paracellular chloride channel in the kidney and requires claudin-8 for tight junction localization. Proc Natl Acad Sci $U S A, 107(42): 18010-5,2010$. ISSN 1091-6490 (Electronic) 0027-8424 (Linking). doi: 10.1073/pnas.1009399107. URL https://www.ncbi.nlm.nih.gov/pubmed/20921420.

[91] V. W. Hsu, M. Bai, and J. Li. Getting active: protein sorting in endocytic recycling. Nat Rev Mol Cell Biol, 13(5):323-8, 2012. ISSN 1471-0080 (Electronic) 1471-0072 (Linking). doi: 10.1038/nrm3332. URL https://www.ncbi.nlm.nih.gov/pubmed/22498832.

[92] R. J. Hung, C. W. Pak, and J. R. Terman. Direct redox regulation of f-actin assembly and disassembly by mical. Science, 334(6063):1710-3, 2011. ISSN 1095-9203 (Electronic) 0036-8075 (Linking). doi: 10.1126/science.1211956. URL https://www.ncbi.nlm.nih.gov/pubmed/22116028.

[93] S. Huveneers, J. Oldenburg, E. Spanjaard, G. van der Krogt, I. Grigoriev, A. Akhmanova, H. Rehmann, and J. de Rooij. Vinculin associates with endothelial ve-cadherin junctions to control force-dependent remodeling. $J$ Cell Biol, 196(5):641-52, 2012. ISSN 1540-8140 (Electronic) 0021-9525 (Linking). doi: 10.1083/jcb.201108120. URL https://www.ncbi.nlm.nih.gov/pubmed/22391038. 
[94] A. Ikari, S. Matsumoto, H. Harada, K. Takagi, H. Hayashi, Y. Suzuki, M. Degawa, and M. Miwa. Phosphorylation of paracellin-1 at ser217 by protein kinase $a$ is essential for localization in tight junctions. $J$ Cell Sci, 119(Pt 9):1781-9, 2006. ISSN 0021-9533 (Print) 0021-9533 (Linking). doi: 10.1242/jcs.02901. URL https://www.ncbi.nlm.nih.gov/pubmed/16608877.

[95] A. Ikari, A. Takiguchi, K. Atomi, and J. Sugatani. Epidermal growth factor increases clathrin-dependent endocytosis and degradation of claudin-2 protein in mdck ii cells. $J$ Cell Physiol, 226(9):2448-56, 2011. ISSN 1097-4652 (Electronic) 0021-9541 (Linking). doi: 10.1002/jcp.22590. URL https://www.ncbi.nlm.nih.gov/pubmed/21660968.

[96] A. Ikari, C. Tonegawa, A. Sanada, T. Kimura, H. Sakai, H. Hayashi, H. Hasegawa, M. Yamaguchi, Y. Yamazaki, S. Endo, T. Matsunaga, and J. Sugatani. Tight junctional localization of claudin-16 is regulated by syntaxin 8 in renal tubular epithelial cells. $J$ Biol Chem, 289 (19):13112-23, 2014. ISSN 1083-351X (Electronic) 00219258 (Linking). doi: 10.1074/jbc.M113.541193. URL https://www.ncbi.nlm.nih.gov/pubmed/24659781.

[97] J. Ikenouchi, K. Umeda, S. Tsukita, M. Furuse, and S. Tsukita. Requirement of zo-1 for the formation of beltlike adherens junctions during epithelial cell polarization. $J$ Cell Biol, 176(6):779-86, 2007. ISSN 0021-9525 (Print) 0021-9525 (Linking). doi: 10.1083/jcb.200612080. URL https://www.ncbi.nlm.nih.gov/pubmed/17353356.

[98] N. Ishiyama, S. H. Lee, S. Liu, G. Y. Li, M. J. Smith, L. F. Reichardt, and M. Ikura. Dynamic and static interactions between p120 catenin and e-cadherin regulate the stability of cell-cell adhesion. Cell, 141 (1):117-28, 2010. ISSN 1097-4172 (Electronic) 00928674 (Linking). doi: 10.1016/j.cell.2010.01.017. URL https://www.ncbi.nlm.nih.gov/pubmed/20371349.

[99] M. Itoh, M. Furuse, K. Morita, K. Kubota, M. Saitou, and S. Tsukita. Direct binding of three tight junction-associated maguks, zo-1, zo-2, and zo-3, with the cooh termini of claudins. J Cell Biol, 147(6):1351-63, 1999. ISSN 0021-9525 (Print) 0021-9525 (Linking). doi: 10.1083/jcb.147.6.1351. URL https://www.ncbi.nlm.nih.gov/pubmed/10601346.

[100] A. I. Ivanov, A. Nusrat, and C. A. Parkos. Endocytosis of epithelial apical junctional proteins by a clathrinmediated pathway into a unique storage compartment. Mol Biol Cell, 15(1):176-88, 2004. ISSN 1059-1524 (Print) 1059-1524 (Linking). doi: 10.1091/mbc.e03-05-0319. URL https://www.ncbi.nlm.nih.gov/pubmed/14528017.

[101] G. Izumi, T. Sakisaka, T. Baba, S. Tanaka, K. Morimoto, and Y. Takai. Endocytosis of e-cadherin regulated by rac and cdc42 small g proteins through iqgap1 and actin filaments. J Cell Biol, 166(2):237-48, 2004. ISSN 0021-9525 (Print) 0021-9525 (Linking). doi: 10.1083/jcb.200401078. URL https://www.ncbi.nlm.nih.gov/pubmed/15263019.

[102] B. Jeansonne, Q. Lu, D. A. Goodenough, and Y. H. Chen. Claudin-8 interacts with multi-pdz domain protein 1 (mupp1) and reduces paracellular conductance in epithelial cells. Cell Mol Biol (Noisy-le-grand), 49(1):13-21, 2003. ISSN 0145-5680 (Print) 0145-5680 (Linking). URL http://www.ncbi.nlm.nih.gov/pubmed/12839333.

[103] H. B. Jefferies, F. T. Cooke, P. Jat, C. Boucheron, T. Koizumi, M. Hayakawa, H. Kaizawa, T. Ohishi, P. Workman, M. D. Waterfield, and P. J. Parker. A selective pikfyve inhibitor blocks ptdins $(3,5) \mathrm{p}(2)$ production and disrupts endomembrane transport and retroviral budding. EMBO Rep, 9(2):164-70, 2008. ISSN 1469-221X (Print) 1469221X (Linking). doi: 10.1038/sj.embor.7401155. URL https://www.ncbi.nlm.nih.gov/pubmed/18188180.
[104] Y. Jiang, Y. R. Li, H. Tian, M. Ma, and H. Matsunami. Muscarinic acetylcholine receptor m3 modulates odorant receptor activity via inhibition of beta-arrestin-2 recruitment. Nat Commun, 6:6448, 2015. ISSN 2041-1723 (Electronic) 2041-1723 (Linking). doi: 10.1038/ncomms7448. URL https://www.ncbi.nlm.nih.gov/pubmed/25800153.

[105] L. S. Johnson, K. W. Dunn, B. Pytowski, and T. E. McGraw. Endosome acidification and receptor trafficking: bafilomycin a1 slows receptor externalization by a mechanism involving the receptor's internalization motif. $\mathrm{Mol}$ Biol Cell, 4(12):1251-66, 1993. ISSN 1059-1524 (Print) 1059-1524 (Linking). doi: 10.1091/mbc.4.12.1251. URL https://www.ncbi.nlm.nih.gov/pubmed/8167408.

[106] D. J. Katzmann, M. Babst, and S. D. Emr. Ubiquitindependent sorting into the multivesicular body pathway requires the function of a conserved endosomal protein sorting complex, escrt-i. Cell, 106(2):14555 , 2001. ISSN 0092-8674 (Print) 0092-8674 (Linking). doi: 10.1016/s0092-8674(01)00434-2. URL https://www.ncbi.nlm.nih.gov/pubmed/11511343.

[107] D. J. Katzmann, G. Odorizzi, and S. D. Emr. Receptor downregulation and multivesicular-body sorting. Nat Rev Mol Cell Biol, 3(12):893-905, 2002. ISSN 1471-0072 (Print) 1471-0072 (Linking). doi: 10.1038/nrm973. URL https://www.ncbi.nlm.nih.gov/pubmed/12461556.

[108] U. Kern, V. Wischnewski, M. L. Biniossek, O. Schilling, and T. Reinheckel. Lysosomal protein turnover contributes to the acquisition of tgfbeta-1 induced invasive properties of mammary cancer cells. Mol Cancer, 14:39, 2015. ISSN 1476-4598 (Electronic) 14764598 (Linking). doi: 10.1186/s12943-015-0313-5. URL https://www.ncbi.nlm.nih.gov/pubmed/25744631.

[109] T. Kimura, T. Sakisaka, T. Baba, T. Yamada, and Y. Takai. Involvement of the ras-ras-activated rab5 guanine nucleotide exchange factor rin2-rab5 pathway in the hepatocyte growth factor-induced endocytosis of e-cadherin. $J$ Biol Chem, 281(15):10598-609, 2006. ISSN 0021-9258 (Print) 00219258 (Linking). doi: 10.1074/jbc.M510531200. URL https://www.ncbi.nlm.nih.gov/pubmed/16423831.

[110] K. B. Kostelnik, A. Barker, C. Schultz, V. Rajeeve, I. J. White, M. Aurrand-Lions, S. Nourshargh, P. Cutillas, and N. T. D. Dynamic trafficking and turnover of jam-c is essential for endothelial cell migration. bioRxiv, 2019. doi: $10.1101 / 625913$.

[111] P. Kota, E. M. Terrell, D. A. Ritt, C. Insinna, C. J. Westlake, and D. K. Morrison. M-ras/shoc2 signaling modulates e-cadherin turnover and cell-cell adhesion during collective cell migration. Proc Natl Acad Sci U SA, 116 (9):3536-3545, 2019. ISSN 1091-6490 (Electronic) 00278424 (Linking). doi: 10.1073/pnas.1805919116. URL https://www.ncbi.nlm.nih.gov/pubmed/30808747.

[112] S. Kurita, T. Yamada, E. Rikitsu, W. Ikeda, and Y. Takai. Binding between the junctional proteins afadin and plekha7 and implication in the formation of adherens junction in epithelial cells. $J$ Biol Chem, 288 (41):29356-68, 2013. ISSN 1083-351X (Electronic) 00219258 (Linking). doi: 10.1074/jbc.M113.453464. URL https://www.ncbi.nlm.nih.gov/pubmed/23990464.

[113] S. Kuroda, M. Fukata, K. Kobayashi, M. Nakafuku, N. Nomura, A. Iwamatsu, and K. Kaibuchi. Identification of iqgap as a putative target for the small gtpases, cdc42 and rac1. $J$ Biol Chem, 271(38):23363-7, 1996. ISSN 0021-9258 (Print) 0021-9258 (Linking). doi: 10.1074/jbc.271.38.23363. URL https://www.ncbi.nlm.nih.gov/pubmed/8798539.

[114] C. Lamagna, P. Meda, G. Mandicourt, J. Brown, R. J. Gilbert, E. Y. Jones, F. Kiefer, P. Ruga, B. A. Imhof, 
and M. Aurrand-Lions. Dual interaction of jam-c with jam-b and alpha(m)beta2 integrin: function in junctional complexes and leukocyte adhesion. Mol Biol Cell, 16 (10):4992-5003, 2005. ISSN 1059-1524 (Print) 10591524 (Linking). doi: 10.1091/mbc.e05-04-0310. URL https://www.ncbi.nlm.nih.gov/pubmed/16093349.

[115] M. G. Lampugnani, M. Corada, L. Caveda, F. Breviario, O. Ayalon, B. Geiger, and E. Dejana. The molecular organization of endothelial cell to cell junctions: differential association of plakoglobin, beta-catenin, and alphacatenin with vascular endothelial cadherin (ve-cadherin). $J$ Cell Biol, 129(1):203-17, 1995. ISSN 0021-9525 (Print) 0021-9525 (Linking). doi: 10.1083/jcb.129.1.203. URL https://www.ncbi.nlm.nih.gov/pubmed/7698986.

[116] M. G. Lampugnani, F. Orsenigo, M. C. Gagliani, C. Tacchetti, and E. Dejana. Vascular endothelial cadherin controls vegfr-2 internalization and signaling from intracellular compartments. J Cell Biol, 174(4):593-604, 2006. ISSN 0021-9525 (Print) 0021-9525 (Linking). doi: 10.1083/jcb.200602080. URL https://www.ncbi.nlm.nih.gov/pubmed/16893970.

[117] M. A. Lanaspa, A. Andres-Hernando, C. J. Rivard, Y. Dai, and T. Berl. Hypertonic stress increases claudin-4 expression and tight junction integrity in association with mupp1 in imcd3 cells. Proc Natl Acad Sci U S A, 105 (41):15797-802, 2008. ISSN 1091-6490 (Electronic) 00278424 (Linking). doi: 10.1073/pnas.0805761105. URL http://www.ncbi.nlm.nih.gov/pubmed/18840681.

[118] J. Langevin, M. J. Morgan, J. B. Sibarita, S. Aresta, M. Murthy, T. Schwarz, J. Camonis, and Y. Bellaiche. Drosophila exocyst components sec5, sec6, and sec15 regulate de-cadherin trafficking from recycling endosomes to the plasma membrane. Dev Cell, 9 (3):365-76, 2005. ISSN 1534-5807 (Print) 1534-5807 (Linking). doi: 10.1016/j.devcel.2005.07.013. URL https://www.ncbi.nlm.nih.gov/pubmed/16224820.

[119] J. M. Larkin, M. S. Brown, J. L. Goldstein, and R. G. Anderson. Depletion of intracellular potassium arrests coated pit formation and receptor-mediated endocytosis in fibroblasts. Cell, 33(1):273-85, 1983. ISSN 0092-8674 (Print) 00928674 (Linking). doi: 10.1016/0092-8674(83)90356-2. URL https://www.ncbi.nlm.nih.gov/pubmed/6147196.

[120] M. Lavie, L. Linna, R. I. Moustafa, S. Belouzard, M. Fukasawa, and J. Dubuisson. Role of the cytosolic domain of occludin in trafficking and hepatitis c virus infection. Traffic, 20(10):753-773, 2019. ISSN 1600-0854 (Electronic) 1398-9219 (Linking). doi: 10.1111/tra.12680. URL https://www.ncbi.nlm.nih.gov/pubmed/31328852.

[121] T. L. Le, A. S. Yap, and J. L. Stow. Recycling of e-cadherin: a potential mechanism for regulating cadherin dynamics. J Cell Biol, 146(1):219-32, 1999. ISSN 0021-9525 (Print) 0021-9525 (Linking). URL https://www.ncbi.nlm.nih.gov/pubmed/10402472.

[122] A. Leibfried, R. Fricke, M. J. Morgan, S. Bogdan, and Y. Bellaiche. Drosophila cip4 and wasp define a branch of the cdc42-par6-apkc pathway regulating e-cadherin endocytosis. Curr Biol, 18(21):1639-48, 2008. ISSN 0960-9822 (Print) 0960-9822 (Linking). doi: 10.1016/j.cub.2008.09.063. URL https://www.ncbi.nlm.nih.gov/pubmed/18976911.

[123] Y. Li, A. S. Fanning, J. M. Anderson, and A. Lavie. Structure of the conserved cytoplasmic c-terminal domain of occludin: identification of the zo-1 binding surface. $J \mathrm{Mol}$ Biol, 352(1):151-64, 2005. ISSN 0022-2836 (Print) 00222836 (Linking). doi: 10.1016/j.jmb.2005.07.017. URL https://www.ncbi.nlm.nih.gov/pubmed/16081103.
[124] A. J. Lindsay and M. W. McCaffrey. The c2 domains of the class i rab11 family of interacting proteins target recycling vesicles to the plasma membrane. $J$ Cell Sci, 117(Pt 19):4365-75, 2004. ISSN 0021-9533 (Print) 0021-9533 (Linking). doi: 10.1242/jcs.01280. URL https://www.ncbi.nlm.nih.gov/pubmed/15304524.

[125] K. Ling, S. F. Bairstow, C. Carbonara, D. A. Turbin, D. G. Huntsman, and R. A. Anderson. Type i gamma phosphatidylinositol phosphate kinase modulates adherens junction and e-cadherin trafficking via a direct interaction with mu 1 b adaptin. J Cell Biol, 176(3):343-53, 2007. ISSN 0021-9525 (Print) 0021-9525 (Linking). doi: 10.1083/jcb.200606023. URL https://www.ncbi.nlm.nih.gov/pubmed/17261850.

[126] F. Liu, M. Koval, S. Ranganathan, S. Fanayan, W. S. Hancock, E. K. Lundberg, R. C. Beavis, L. Lane, P. Duek, L. McQuade, N. L. Kelleher, and M. S. Baker. Systems proteomics view of the endogenous human claudin protein family. $J$ Proteome Res, 15(2):339-59, 2016. ISSN 1535-3907 (Electronic) 1535-3893 (Linking). doi: 10.1021/acs.jproteome.5b00769. URL https://www.ncbi.nlm.nih.gov/pubmed/26680015.

[127] J. Liu, X. Jin, K. J. Liu, and W. Liu. Matrix metalloproteinase-2-mediated occludin degradation and caveolin-1-mediated claudin-5 redistribution contribute to blood-brain barrier damage in early ischemic stroke stage. $J$ Neurosci, 32(9):3044-57, 2012. ISSN 1529-2401 (Electronic) 0270-6474 (Linking). doi: 10.1523/JNEUROSCI.6409-11.2012. URL https://www.ncbi.nlm.nih.gov/pubmed/22378877.

[128] J. Liu, J. Weaver, X. Jin, Y. Zhang, J. Xu, K. J. Liu, W. Li, and W. Liu. Nitric oxide interacts with caveolin-1 to facilitate autophagy-lysosome-mediated claudin-5 degradation in oxygen-glucose deprivation-treated endothelial cells. $\mathrm{Mol}$ Neurobiol, 53(9):5935-5947, 2016. ISSN 1559-1182 (Electronic) 0893-7648 (Linking). doi: 10.1007/s12035-015-9504-8. URL https://www.ncbi.nlm.nih.gov/pubmed/26515186.

[129] J. G. Lock and J. L. Stow. Rab11 in recycling endosomes regulates the sorting and basolateral transport of e-cadherin. Mol Biol Cell, 16(4):1744-55, 2005. ISSN 1059-1524 (Print) 1059-1524 (Linking). doi: 10.1091/mbc.e04-10-0867. URL https://www.ncbi.nlm.nih.gov/pubmed/15689490.

[130] J. G. Lock, L. A. Hammond, F. Houghton, P. A. Gleeson, and J. L. Stow. E-cadherin transport from the trans-golgi network in tubulovesicular carriers is selectively regulated by golgin97. Traffic, 6(12):1142-56, 2005. ISSN 1398-9219 (Print) 1398-9219 (Linking). doi: 10.1111/j.1600-0854.2005.00349.x. URL https://www.ncbi.nlm.nih.gov/pubmed/16262725.

[131] S. H. Low, M. Miura, P. A. Roche, A. C. Valdez, K. E. Mostov, and T. Weimbs. Intracellular redirection of plasma membrane trafficking after loss of epithelial cell polarity. Mol Biol Cell, 11(9):3045-60, 2000. ISSN 1059-1524 (Print) 1059-1524 (Linking). doi: 10.1091/mbc.11.9.3045. URL https://www.ncbi.nlm.nih.gov/pubmed/10982399.

[132] R. Lu, D. L. Johnson, L. Stewart, K. Waite, D. Elliott, and J. M. Wilson. Rab14 regulation of claudin-2 trafficking modulates epithelial permeability and lumen morphogenesis. Mol Biol Cell, 25(11):1744-54, 2014. ISSN 1939-4586 (Electronic) 1059-1524 (Linking). doi: 10.1091/mbc.E13-12-0724. URL https://www.ncbi.nlm.nih.gov/pubmed/24694596.

[133] S. Lucken-Ardjomande Hasler, Y. Vallis, M. Pasche, and H. T. McMahon. Graf2, wdr44, and mical1 mediate rab8/10/11dependent export of e-cadherin, mmp14, and cftr deltaf508. J Cell Biol, 219(5), 2020. ISSN 1540-8140 (Electronic) 0021-9525 (Linking). doi: 10.1083/jcb.201811014. URL https://www.ncbi.nlm.nih.gov/pubmed/32344433.

[134] L. Ma, R. Rohatgi, and M. W. Kirschner. The arp2/3 complex mediates actin polymerization induced by the small 
gtp-binding protein cdc42. Proc Natl Acad Sci $U$ S $A$, 95(26):15362-7, 1998. ISSN 0027-8424 (Print) 00278424 (Linking). doi: 10.1073/pnas.95.26.15362. URL https://www.ncbi.nlm.nih.gov/pubmed/9860974.

[135] E. Macia, M. Ehrlich, R. Massol, E. Boucrot, C. Brunner, and T. Kirchhausen. Dynasore, a cell-permeable inhibitor of dynamin. Dev Cell, 10(6):839-50, 2006. ISSN 1534-5807 (Print) 1534-5807 (Linking). doi: 10.1016/j.devcel.2006.04.002. URL https://www.ncbi.nlm.nih.gov/pubmed/16740485.

[136] K. Mandai, Y. Rikitake, M. Mori, and Y. Takai. Nectins and nectin-like molecules in development and disease. Curr Top Dev Biol, 112:197-231, 2015. ISSN 1557-8933 (Electronic) 0070-2153 (Linking). doi: 10.1016/bs.ctdb.2014.11.019. URL https://www.ncbi.nlm.nih.gov/pubmed/25733141.

[137] I. Mandel, T. Paperna, A. Volkowich, M. Merhav, L. GlassMarmor, and A. Miller. The ubiquitin-proteasome pathway regulates claudin 5 degradation. $J$ Cell Biochem, 113(7):2415-23, 2012. ISSN 1097-4644 (Electronic) 0730-2312 (Linking). doi: 10.1002/jcb.24118. URL https://www.ncbi.nlm.nih.gov/pubmed/22389112.

[138] A. M. Marchiando, L. Shen, W. V. Graham, C. R. Weber, B. T. Schwarz, n. Austin, J. R., D. R. Raleigh, Y. Guan, A. J. Watson, M. H. Montrose, and J. R. Turner. Caveolin-1-dependent occludin endocytosis is required for tnf-induced tight junction regulation in vivo. $J$ Cell Biol, 189(1):111-26, 2010. ISSN 1540-8140 (Electronic) 0021-9525 (Linking). doi: 10.1083/jcb.200902153. URL https://www.ncbi.nlm.nih.gov/pubmed/20351069.

[139] K. Marunaka, C. Furukawa, N. Fujii, T. Kimura, T. Furuta, T. Matsunaga, S. Endo, H. Hasegawa, N. Anzai, Y. Yamazaki, M. Yamaguchi, and A. Ikari. The ring finger- and pdz domaincontaining protein pdzrn3 controls localization of the $\mathrm{mg}(2+)$ regulator claudin-16 in renal tube epithelial cells. J Biol Chem, 292(31):13034-13044, 2017. ISSN 1083-351X (Electronic) 0021-9258 (Linking). doi: 10.1074/jbc.M117.779405. URL https://www.ncbi.nlm.nih.gov/pubmed/28623232.

[140] A. M. Marzesco, I. Dunia, R. Pandjaitan, M. Recouvreur, D. Dauzonne, E. L. Benedetti, D. Louvard, and A. Zahraoui. The small gtpase rab13 regulates assembly of functional tight junctions in epithelial cells. Mol Biol Cell, 13(6):1819-31, 2002. ISSN 1059-1524 (Print) 1059-1524 (Linking). doi: 10.1091/mbc.02-02-0029. URL https://www.ncbi.nlm.nih.gov/pubmed/12058051.

[141] M. Matsuda, A. Kubo, M. Furuse, and S. Tsukita. A peculiar internalization of claudins, tight junction-specific adhesion molecules, during the intercellular movement of epithelial cells. J Cell Sci, 117(Pt 7):1247-57, 2004. ISSN 0021-9533 (Print) 0021-9533 (Linking). doi: 10.1242/jcs.00972. URL https://www.ncbi.nlm.nih.gov/pubmed/14996944.

[142] T. Matsui, T. Watanabe, K. Matsuzawa, M. Kakeno, N. Okumura, I. Sugiyama, N. Itoh, and K. Kaibuchi. Par3 and apkc regulate golgi organization through clasp2 phosphorylation to generate cell polarity. Mol Biol Cell, 26(4):751-61, 2015. ISSN 1939-4586 (Electronic) 10591524 (Linking). doi: 10.1091/mbc.E14-09-1382. URL https://www.ncbi.nlm.nih.gov/pubmed/25518939.

[143] P. D. McCrea and C. J. Gottardi. Beyond beta-catenin: prospects for a larger catenin network in the nucleus. Nat Rev Mol Cell Biol, 17(1):55-64, 2016. ISSN 1471-0080 (Electronic) 1471-0072 (Linking). doi: 10.1038/nrm.2015.3. URL https://www.ncbi.nlm.nih.gov/pubmed/26580716.

[144] A. E. McEwen, M. T. Maher, R. Mo, and C. J. Gottardi. E-cadherin phosphorylation occurs during its biosynthesis to promote its cell surface stability and adhesion. Mol Biol Cell, 25(16):2365-74, 2014. ISSN 1939-4586 (Electronic) 1059-1524 (Linking). doi: 10.1091/mbc.E14-01-0690. URL https://www.ncbi.nlm.nih.gov/pubmed/24966173.
[145] C. L. Mendelsohn, E. Wimmer, and V. R. Racaniello. Cellular receptor for poliovirus: molecular cloning, nucleotide sequence, and expression of a new member of the immunoglobulin superfamily. Cell, 56 (5):855-65, 1989. ISSN 0092-8674 (Print) 0092-8674 (Linking). doi: 10.1016/0092-8674(89)90690-9. URL https://www.ncbi.nlm.nih.gov/pubmed/2538245.

[146] W. Meng and M. Takeichi. Adherens junction: molecular architecture and regulation. Cold Spring Harb Perspect Biol, 1(6):a002899, 2009. ISSN 1943-0264 (Electronic) 19430264 (Linking). doi: 10.1101/cshperspect.a002899. URL https://www.ncbi.nlm.nih.gov/pubmed/20457565.

[147] K. C. Miranda, S. R. Joseph, A. S. Yap, R. D. Teasdale, and J. L. Stow. Contextual binding of p120ctn to e-cadherin at the basolateral plasma membrane in polarized epithelia. $J$ Biol Chem, 278(44):43480-8, 2003. ISSN 0021-9258 (Print) 0021-9258 (Linking). doi: 10.1074/jbc.M305525200. URL https://www.ncbi.nlm.nih.gov/pubmed/12923199.

[148] M. Miyahara, H. Nakanishi, K. Takahashi, K. SatohHorikawa, K. Tachibana, and Y. Takai. Interaction of nectin with afadin is necessary for its clustering at cell-cell contact sites but not for its cis dimerization or trans interaction. J Biol Chem, 275(1):613-8, 2000. ISSN 0021-9258 (Print) 0021-9258 (Linking). doi: 10.1074/jbc.275.1.613. URL https://www.ncbi.nlm.nih.gov/pubmed/10617658.

[149] Y. Miyashita and M. Ozawa. Increased internalization of p120-uncoupled e-cadherin and a requirement for a dileucine motif in the cytoplasmic domain for endocytosis of the protein. J Biol Chem, 282(15):11540-8, 2007. ISSN 0021-9258 (Print) 0021-9258 (Linking). doi: 10.1074/jbc.M608351200. URL https://www.ncbi.nlm.nih.gov/pubmed/17298950.

[150] Y. Miyashita and M. Ozawa. A dileucine motif in its cytoplasmic domain directs beta-catenin-uncoupled e-cadherin to the lysosome. J Cell Sci, 120(Pt 24):4395-406, 2007. ISSN 00219533 (Print) 0021-9533 (Linking). doi: 10.1242/jcs.03489. URL https://www.ncbi.nlm.nih.gov/pubmed/18057030.

[151] Y. Momose, T. Honda, M. Inagaki, K. Shimizu, K. Irie, H. Nakanishi, and Y. Takai. Role of the second immunoglobulin-like loop of nectin in cell-cell adhesion. Biochem Biophys Res Commun, 293(1):459, 2002. ISSN 0006-291X (Print) 0006-291X (Linking). doi: 10.1016/S0006-291X(02)00183-3. URL https://www.ncbi.nlm.nih.gov/pubmed/12054561.

[152] A. C. Monteiro, A. C. Luissint, R. Sumagin, C. Lai, F. Vielmuth, M. F. Wolf, O. Laur, K. Reiss, V. Spindler, T. Stehle, T. S. Dermody, A. Nusrat, and C. A. Parkos. Transdimerization of jam-a regulates rap2 and is mediated by a domain that is distinct from the cis-dimerization interface. Mol Biol Cell, 25(10):1574-85, 2014. ISSN 1939-4586 (Electronic) 1059-1524 (Linking). doi: 10.1091/mbc.E14-01-0018. URL https://www.ncbi.nlm.nih.gov/pubmed/24672055.

[153] S. Morimoto, N. Nishimura, T. Terai, S. Manabe, Y. Yamamoto, W. Shinahara, H. Miyake, S. Tashiro, M. Shimada, and T. Sasaki. Rab13 mediates the continuous endocytic recycling of occludin to the cell surface. $J$ Biol Chem, 280(3):2220-8, 2005. ISSN 0021-9258 (Print) 0021-9258 (Linking). doi: 10.1074/jbc.M406906200. URL https://www.ncbi.nlm.nih.gov/pubmed/15528189.

[154] K. Morita, H. Sasaki, M. Furuse, and S. Tsukita. Endothelial claudin: claudin-5/tmvcf constitutes tight junction strands in endothelial cells. J Cell Biol, 147(1):185-94, 1999. ISSN 00219525 (Print) 0021-9525 (Linking). doi: 10.1083/jcb.147.1.185. URL https://www.ncbi.nlm.nih.gov/pubmed/10508865.

[155] S. Moskalenko, D. O. Henry, C. Rosse, G. Mirey, J. H. Camonis, and M. A. White. The exocyst is a ral effector complex. Nat Cell Biol, 4(1):66-72, 2002. ISSN 1465-7392 
(Print) 1465-7392 (Linking). doi: 10.1038/ncb728. URL https://www.ncbi.nlm.nih.gov/pubmed/11740492.

[156] A. L. Moss and W. F. Ward. Multiple pathways for ligand internalization in rat hepatocytes. i: Effects of anoxia, phenylarsine oxide and monensin. J Cell Physiol, 149(2):313-8, 1991. ISSN 0021-9541 (Print) 00219541 (Linking). doi: 10.1002/jcp.1041490219. URL https://www.ncbi.nlm.nih.gov/pubmed/1721073.

[157] D. Muller, P. J. Kausalya, F. Claverie-Martin, I. C. Meij, P. Eggert, V. Garcia-Nieto, and W. Hunziker. A novel claudin 16 mutation associated with childhood hypercalciuria abolishes binding to zo-1 and results in lysosomal mistargeting. Am J Hum Genet, 73(6):1293-301, 2003. ISSN 0002-9297 (Print) 0002-9297 (Linking). doi: 10.1086/380418. URL https://www.ncbi.nlm.nih.gov/pubmed/14628289.

[158] D. Muller, P. J. Kausalya, I. C. Meij, and W. Hunziker. Familial hypomagnesemia with hypercalciuria and nephrocalcinosis: blocking endocytosis restores surface expression of a novel claudin-16 mutant that lacks the entire c-terminal cytosolic tail. Hum Mol Genet, 15(7):1049-58, 2006. ISSN 09646906 (Print) 0964-6906 (Linking). doi: 10.1093/hmg/ddl020. URL https://www.ncbi.nlm.nih.gov/pubmed/16501001.

[159] S. L. Muller, M. Portwich, A. Schmidt, D. I. Utepbergenov, O. Huber, I. E. Blasig, and G. Krause. The tight junction protein occludin and the adherens junction protein alphacatenin share a common interaction mechanism with zo-1. J Biol Chem, 280(5):3747-56, 2005. ISSN 0021-9258 (Print) 0021-9258 (Linking). doi: 10.1074/jbc.M411365200. URL https://www.ncbi.nlm.nih.gov/pubmed/15548514.

[160] T. Murakami, E. A. Felinski, and D. A. Antonetti. Occludin phosphorylation and ubiquitination regulate tight junction trafficking and vascular endothelial growth factor-induced permeability. J Biol Chem, 284(31): 21036-46, 2009. ISSN 1083-351X (Electronic) 00219258 (Linking). doi: 10.1074/jbc.M109.016766. URL https://www.ncbi.nlm.nih.gov/pubmed/19478092.

[161] T. Murakami, T. Frey, C. Lin, and D. A. Antonetti. Protein kinase cbeta phosphorylates occludin regulating tight junction trafficking in vascular endothelial growth factor-induced permeability in vivo. Diabetes, 61(6):1573-83, 2012. ISSN 1939-327X (Electronic) 0012-1797 (Linking). doi: 10.2337/db11-1367. URL https://www.ncbi.nlm.nih.gov/pubmed/22438576.

[162] R. Z. Murray, L. A. Jolly, and S. A. Wood. The fam deubiquitylating enzyme localizes to multiple points of protein trafficking in epithelia, where it associates with e-cadherin and betacatenin. Mol Biol Cell, 15(4):1591-9, 2004. ISSN 1059-1524 (Print) 1059-1524 (Linking). doi: 10.1091/mbc.e03-08-0630. URL https://www.ncbi.nlm.nih.gov/pubmed/14742711.

[163] S. Nada, A. Hondo, A. Kasai, M. Koike, K. Saito, Y. Uchiyama, and M. Okada. The novel lipid raft adaptor p18 controls endosome dynamics by anchoring the mek-erk pathway to late endosomes. EMBO J, 28(5):477-89, 2009. ISSN 1460-2075 (Electronic) 02614189 (Linking). doi: 10.1038/emboj.2008.308. URL https://www.ncbi.nlm.nih.gov/pubmed/19177150.

[164] S. Nakashima, K. Morinaka, S. Koyama, M. Ikeda, M. Kishida, K. Okawa, A. Iwamatsu, S. Kishida, and A. Kikuchi. Small g protein ral and its downstream molecules regulate endocytosis of egf and insulin receptors. EMBO $J$, 18(13):3629-42, 1999. ISSN 0261-4189 (Print) 02614189 (Linking). doi: 10.1093/emboj/18.13.3629. URL https://www.ncbi.nlm.nih.gov/pubmed/10393179.

[165] H. Nakatsuji, N. Nishimura, R. Yamamura, H. O. Kanayama, and T. Sasaki. Involvement of actinin-4 in the recruitment of jrab/mical-12 to cell-cell junctions and the formation of functional tight junctions. Mol Cell Biol, 28
(10):3324-35, 2008. ISSN 1098-5549 (Electronic) 02707306 (Linking). doi: 10.1128/MCB.00144-08. URL https://www.ncbi.nlm.nih.gov/pubmed/18332111.

[166] B. A. Nanes, C. Chiasson-MacKenzie, A. M. Lowery, N. Ishiyama, V. Faundez, M. Ikura, P. A. Vincent, and A. P. Kowalczyk. p120-catenin binding masks an endocytic signal conserved in classical cadherins. $J$ Cell Biol, 199(2):365-80, 2012. ISSN 1540-8140 (Electronic) 0021-9525 (Linking). doi: 10.1083/jcb.201205029. URL https://www.ncbi.nlm.nih.gov/pubmed/23071156.

[167] S. P. Ngok, R. Geyer, M. Liu, A. Kourtidis, S. Agrawal, C. Wu, H. R. Seerapu, L. J. Lewis-Tuffin, K. L. Moodie, D. Huveldt, R. Marx, J. M. Baraban, P. Storz, A. Horowitz, and P. Z. Anastasiadis. Vegf and angiopoietin-1 exert opposing effects on cell junctions by regulating the rho gef syx. J Cell Biol, 199(7):1103-15, 2012. ISSN 1540-8140 (Electronic) 0021-9525 (Linking). doi: 10.1083/jcb.201207009. URL https://www.ncbi.nlm.nih.gov/pubmed/23253477.

[168] R. L. Nokes, I. C. Fields, R. N. Collins, and H. Folsch. Rab13 regulates membrane trafficking between tgn and recycling endosomes in polarized epithelial cells. $J$ Cell Biol, 182(5):845-53, 2008. ISSN 1540-8140 (Electronic) 0021-9525 (Linking). doi: 10.1083/jcb.200802176. URL https://www.ncbi.nlm.nih.gov/pubmed/18779367.

[169] J. Nomme, A. Antanasijevic, M. Caffrey, C. M. Van Itallie, J. M. Anderson, A. S. Fanning, and A. Lavie. Structural basis of a key factor regulating the affinity between the zonula occludens first pdz domain and claudins. $J$ Biol Chem, 290(27):16595-606, 2015. ISSN 1083-351X (Electronic) 0021-9258 (Linking). doi: 10.1074/jbc.M115.646695. URL https://www.ncbi.nlm.nih.gov/pubmed/26023235.

[170] M. Ohba, K. Ishino, M. Kashiwagi, S. Kawabe, K. Chida, N. H. Huh, and T. Kuroki. Induction of differentiation in normal human keratinocytes by adenovirus-mediated introduction of the eta and delta isoforms of protein kinase c. Mol Cell Biol, 18(9):5199-207, 1998. ISSN 0270-7306 (Print) 0270-7306 (Linking). doi: 10.1128/mcb.18.9.5199. URL https://www.ncbi.nlm.nih.gov/pubmed/9710604.

[171] S. Ohtsuki, H. Yamaguchi, Y. Katsukura, T. Asashima, and T. Terasaki. mrna expression levels of tight junction protein genes in mouse brain capillary endothelial cells highly purified by magnetic cell sorting. J Neurochem, 104 (1):147-54, 2008. ISSN 1471-4159 (Electronic) 0022-3042 (Linking). doi: 10.1111/j.1471-4159.2007.05008.x. URL https://www.ncbi.nlm.nih.gov/pubmed/17971126.

[172] T. Ooshio, R. Kobayashi, W. Ikeda, M. Miyata, Y. Fukumoto, N. Matsuzawa, H. Ogita, and Y. Takai. Involvement of the interaction of afadin with zo-1 in the formation of tight junctions in madin-darby canine kidney cells. $J$ Biol Chem, 285(7):5003-12, 2010. ISSN 1083-351X (Electronic) 0021-9258 (Linking). doi: 10.1074/jbc.M109.043760. URL https://www.ncbi.nlm.nih.gov/pubmed/20008323.

[173] V. V. Orlova, M. Economopoulou, F. Lupu, S. Santoso, and T. Chavakis. Junctional adhesion moleculec regulates vascular endothelial permeability by modulating ve-cadherin-mediated cell-cell contacts. $J$ Exp Med, 203(12):2703-14, 2006. ISSN 0022-1007 (Print) 00221007 (Linking). doi: 10.1084/jem.20051730. URL https://www.ncbi.nlm.nih.gov/pubmed/17116731.

[174] S. Osada, K. Mizuno, T. C. Saido, Y. Akita, K. Suzuki, T. Kuroki, and S. Ohno. A phorbol ester receptor/protein kinase, npkc eta, a new member of the protein kinase $\mathrm{c}$ family predominantly expressed in lung and skin. $J$ Biol Chem, 265(36):22434-40, 1990. ISSN 0021-9258 (Print) 0021-9258 (Linking). URL https://www.ncbi.nlm.nih.gov/pubmed/2266135. 
[175] T. Otani, T. P. Nguyen, S. Tokuda, K. Sugihara, T. Sugawara, K. Furuse, T. Miura, K. Ebnet, and M. Furuse. Claudins and jam-a coordinately regulate tight junction formation and epithelial polarity. J Cell Biol, 218(10):3372-3396, 2019. ISSN 1540-8140 (Electronic) 0021-9525 (Linking). doi: 10.1083/jcb.201812157. URL https://www.ncbi.nlm.nih.gov/pubmed/31467165.

[176] Y. Otsuki, M. Tanaka, S. Yoshii, N. Kawazoe, K. Nakaya, and H. Sugimura. Tumor metastasis suppressor nm23h1 regulates rac1 gtpase by interaction with tiam1. Proc Natl Acad Sci U S A, 98(8):4385-90, 2001. ISSN 0027-8424 (Print) 0027-8424 (Linking). doi: 10.1073/pnas.071411598. URL https://www.ncbi.nlm.nih.gov/pubmed/11274357.

[177] M. Ozawa, H. Baribault, and R. Kemler. The cytoplasmic domain of the cell adhesion molecule uvomorulin associates with three independent proteins structurally related in different species. EMBO J, 8(6):1711-7, 1989. ISSN 0261-4189 (Print) 0261-4189 (Linking). URL https://www.ncbi.nlm.nih.gov/pubmed/2788574.

[178] F. Palacios, L. Price, J. Schweitzer, J. G. Collard, and C. D'Souza-Schorey. An essential role for arf6-regulated membrane traffic in adherens junction turnover and epithelial cell migration. EMBO J, 20(17):4973-86, 2001. ISSN 0261-4189 (Print) 0261-4189 (Linking). doi: 10.1093/emboj/20.17.4973. URL https://www.ncbi.nlm.nih.gov/pubmed/11532961.

[179] F. Palacios, J. K. Schweitzer, R. L. Boshans, and C. D'SouzaSchorey. Arf6-gtp recruits nm23-h1 to facilitate dynaminmediated endocytosis during adherens junctions disassembly. Nat Cell Biol, 4(12):929-36, 2002. ISSN 1465-7392 (Print) 1465-7392 (Linking). doi: 10.1038/ncb881. URL https://www.ncbi.nlm.nih.gov/pubmed/12447393.

[180] F. Palacios, J. S. Tushir, Y. Fujita, and C. D'SouzaSchorey. Lysosomal targeting of e-cadherin: a unique mechanism for the down-regulation of cell-cell adhesion during epithelial to mesenchymal transitions. Mol Cell Biol, 25(1):389-402, 2005. ISSN 0270-7306 (Print) 0270-7306 (Linking). doi: 10.1128/MCB.25.1.389-402.2005. URL https://www.ncbi.nlm.nih.gov/pubmed/15601859.

[181] A. D. Paterson, R. G. Parton, C. Ferguson, J. L. Stow, and A. S. Yap. Characterization of e-cadherin endocytosis in isolated mcf-7 and chinese hamster ovary cells: the initial fate of unbound e-cadherin. $J$ Biol Chem, 278(23):21050-7, 2003. ISSN 0021-9258 (Print) 00219258 (Linking). doi: 10.1074/jbc.M300082200. URL https://www.ncbi.nlm.nih.gov/pubmed/12657640.

[182] F. Peglion, F. Llense, and S. Etienne-Manneville. Adherens junction treadmilling during collective migration. Nat Cell Biol, 16(7):639-51, 2014. ISSN 1476-4679 (Electronic) 1465-7392 (Linking). doi: 10.1038/ncb2985. URL https://www.ncbi.nlm.nih.gov/pubmed/24929360.

[183] J. Piontek, L. Winkler, H. Wolburg, S. L. Muller, N. Zuleger, C. Piehl, B. Wiesner, G. Krause, and I. E. Blasig. Formation of tight junction: determinants of homophilic interaction between classic claudins. FASEB J, 22(1):146-58, 2008. ISSN 1530-6860 (Electronic) 08926638 (Linking). doi: 10.1096/fj.07-8319com. URL https://www.ncbi.nlm.nih.gov/pubmed/17761522.

[184] M. D. Potter, S. Barbero, and D. A. Cheresh. Tyrosine phosphorylation of ve-cadherin prevents binding of p120- and beta-catenin and maintains the cellular mesenchymal state. $J$ Biol Chem, 280(36):31906-12, 2005. ISSN 0021-9258 (Print) 0021-9258 (Linking). doi: 10.1074/jbc.M505568200. URL https://www.ncbi.nlm.nih.gov/pubmed/16027153.

[185] R. Prekeris, B. Yang, V. Oorschot, J. Klumperman, and R. H. Scheller. Differential roles of syntaxin 7 and syntaxin 8 in endosomal trafficking. $\mathrm{Mol}$ Biol Cell,
10(11):3891-908, 1999. ISSN 1059-1524 (Print) 10591524 (Linking). doi: 10.1091/mbc.10.11.3891. URL https://www.ncbi.nlm.nih.gov/pubmed/10564279.

[186] J. F. Presley, S. Mayor, T. E. McGraw, K. W. Dunn, and F. R. Maxfield. Bafilomycin a1 treatment retards transferrin receptor recycling more than bulk membrane recycling. $J$ Biol Chem, 272(21):13929-36, 1997. ISSN 0021-9258 (Print) 0021-9258 (Linking). doi: 10.1074/jbc.272.21.13929. URL https://www.ncbi.nlm.nih.gov/pubmed/9153255.

[187] T. Proikas-Cezanne, A. Gaugel, T. Frickey, and A. Nordheim. Rab14 is part of the early endosomal clathrin-coated tgn microdomain. FEBS Lett, 580 (22):5241-6, 2006. ISSN 0014-5793 (Print) 0014-5793 (Linking). doi: 10.1016/j.febslet.2006.08.053. URL https://www.ncbi.nlm.nih.gov/pubmed/16962593.

[188] A. Quan, A. B. McGeachie, D. J. Keating, E. M. van Dam, J. Rusak, N. Chau, C. S. Malladi, C. Chen, A. McCluskey, M. A. Cousin, and P. J. Robinson. Myristyl trimethyl ammonium bromide and octadecyl trimethyl ammonium bromide are surface-active small molecule dynamin inhibitors that block endocytosis mediated by dynamin i or dynamin ii. Mol Pharmacol, 72(6):1425-39, 2007. ISSN 1521-0111 (Electronic) 0026-895X (Linking). doi: 10.1124/mol.107.034207. URL https://www.ncbi.nlm.nih.gov/pubmed/17702890.

[189] A. Rai, A. Oprisko, J. Campos, Y. Fu, T. Friese, A. Itzen, R. S. Goody, E. M. Gazdag, and M. P. Muller. bmerb domains are bivalent rab8 family effectors evolved by gene duplication. Elife, 5, 2016. ISSN 2050-084X (Electronic) 2050-084X (Linking). doi: 10.7554/eLife.18675. URL https://www.ncbi.nlm.nih.gov/pubmed/27552051.

[190] D. R. Raleigh, A. M. Marchiando, Y. Zhang, L. Shen, H. Sasaki, Y. Wang, M. Long, and J. R. Turner. Tight junction-associated marvel proteins marveld3, tricellulin, and occludin have distinct but overlapping functions. Mol Biol Cell, 21(7):1200-13, 2010. ISSN 1939-4586 (Electronic) 1059-1524 (Linking). doi: 10.1091/mbc.E09-08-0734. URL https://www.ncbi.nlm.nih.gov/pubmed/20164257.

[191] S. H. Ramirez, S. Fan, H. Dykstra, S. Rom, A. Mercer, N. L. Reichenbach, L. Gofman, and Y. Persidsky. Inhibition of glycogen synthase kinase 3beta promotes tight junction stability in brain endothelial cells by half-life extension of occludin and claudin-5. PLoS One, 8(2):e55972, 2013. ISSN 1932-6203 (Electronic) 19326203 (Linking). doi: 10.1371/journal.pone.0055972. URL https://www.ncbi.nlm.nih.gov/pubmed/23418486.

[192] E. Regan-Klapisz, V. Krouwer, M. Langelaar-Makkinje, L. Nallan, M. Gelb, H. Gerritsen, A. J. Verkleij, and J. A. Post. Golgi-associated cpla2alpha regulates endothelial cell-cell junction integrity by controlling the trafficking of transmembrane junction proteins. Mol Biol Cell, 20(19):4225-34, 2009. ISSN 1939-4586 (Electronic) 10591524 (Linking). doi: 10.1091/mbc.E08-02-0210. URL https://www.ncbi.nlm.nih.gov/pubmed/19675210.

[193] K. Rehm, L. Panzer, V. van Vliet, E. Genot, and S. Linder. Drebrin preserves endothelial integrity by stabilizing nectin at adherens junctions. $J$ Cell Sci, 126(Pt 16):3756-69, 2013. ISSN 1477-9137 (Electronic) 0021-9533 (Linking). doi: 10.1242/jcs.129437. URL https://www.ncbi.nlm.nih.gov/pubmed/23750010.

[194] V. Renigunta, T. Fischer, M. Zuzarte, S. Kling, X. Zou, K. Siebert, M. M. Limberg, S. Rinne, N. Decher, G. Schlichthorl, and J. Daut. Cooperative endocytosis of the endosomal snare protein syntaxin- 8 and the potassium channel task-1. Mol Biol Cell, 25 (12):1877-91, 2014. ISSN 1939-4586 (Electronic) 10591524 (Linking). doi: 10.1091/mbc.E13-10-0592. URL https://www.ncbi.nlm.nih.gov/pubmed/24743596. 
[195] N. Reymond, S. Fabre, E. Lecocq, J. Adelaide, P. Dubreuil, and M. Lopez. Nectin $4 /$ prr4, a new afadin-associated member of the nectin family that trans-interacts with nectin1/prr1 through $\mathrm{v}$ domain interaction. J Biol Chem, 276(46):43205-15, 2001. ISSN 0021-9258 (Print) 00219258 (Linking). doi: 10.1074/jbc.M103810200. URL https://www.ncbi.nlm.nih.gov/pubmed/11544254.

[196] N. Reymond, S. Garrido-Urbani, J. P. Borg, P. Dubreuil, and M. Lopez. Pick-1: a scaffold protein that interacts with nectins and jams at cell junctions. FEBS Lett, 579(10):2243-9, 2005. ISSN 0014-5793 (Print) 00145793 (Linking). doi: 10.1016/j.febslet.2005.03.010. URL https://www.ncbi.nlm.nih.gov/pubmed/15811349.

[197] K. L. Rock, C. Gramm, L. Rothstein, K. Clark, R. Stein, L. Dick, D. Hwang, and A. L. Goldberg. Inhibitors of the proteasome block the degradation of most cell proteins and the generation of peptides presented on mhc class i molecules. Cell, 78(5):761-71, 1994. ISSN 0092-8674 (Print) 00928674 (Linking). doi: 10.1016/s0092-8674(94)90462-6. URL https://www.ncbi.nlm.nih.gov/pubmed/8087844.

[198] A. Sakane, A. A. Abdallah, K. Nakano, K. Honda, W. Ikeda, Y. Nishikawa, M. Matsumoto, N. Matsushita, T. Kitamura, and T. Sasaki. Rab13 small g protein and junctional rab13binding protein (jrab) orchestrate actin cytoskeletal organization during epithelial junctional development. $J$ Biol Chem, 287(51):42455-68, 2012. ISSN 1083-351X (Electronic) 0021-9258 (Linking). doi: 10.1074/jbc.M112.383653. URL https://www.ncbi.nlm.nih.gov/pubmed/23100251.

[199] T. Sakurai, M. J. Woolls, S. W. Jin, M. Murakami, and M. Simons. Inter-cellular exchange of cellular components via ve-cadherin-dependent trans-endocytosis. PLoS One, 9(6):e90736, 2014. ISSN 1932-6203 (Electronic) 19326203 (Linking). doi: 10.1371/journal.pone.0090736. URL https://www.ncbi.nlm.nih.gov/pubmed/24603875.

[200] K. Sandvig, S. Olsnes, O. W. Petersen, and B. van Deurs. Acidification of the cytosol inhibits endocytosis from coated pits. J Cell Biol, 105(2):679-89, 1987. ISSN 0021-9525 (Print) 0021-9525 (Linking). doi: 10.1083/jcb.105.2.679. URL https://www.ncbi.nlm.nih.gov/pubmed/2887575.

[201] D. Sbrissa, O. C. Ikonomov, and A. Shisheva. Pikfyve, a mammalian ortholog of yeast fab1p lipid kinase, synthesizes 5-phosphoinositides. effect of insulin. $J$ Biol Chem, 274(31):21589-97, 1999. ISSN 0021-9258 (Print) 0021-9258 (Linking). doi: 10.1074/jbc.274.31.21589. URL https://www.ncbi.nlm.nih.gov/pubmed/10419465.

[202] M. S. Scheffers, P. van der Bent, F. Prins, L. Spruit, M. H. Breuning, S. V. Litvinov, E. de Heer, and D. J. Peters. Polycystin-1, the product of the polycystic kidney disease 1 gene, co-localizes with desmosomes in mdck cells. Hum Mol Genet, 9(18):2743-50, 2000. ISSN 0964-6906 (Print) 0964-6906 (Linking). doi: 10.1093/hmg/9.18.2743. URL https://www.ncbi.nlm.nih.gov/pubmed/11063733.

[203] C. Schilpp, R. Lochbaum, P. Braubach, D. Jonigk, M. Frick, P. Dietl, and O. H. Wittekindt. Tgf-beta1 increases permeability of ciliated airway epithelia via redistribution of claudin 3 from tight junction into cell nuclei. Pflugers Arch, 2021. ISSN 1432-2013 (Electronic) 00316768 (Linking). doi: 10.1007/s00424-020-02501-2. URL https://www.ncbi.nlm.nih.gov/pubmed/33386991.

[204] J. A. Schmidt, D. N. Kalkofen, K. W. Donovan, and W. J. Brown. A role for phospholipase a2 activity in membrane tubule formation and tgn trafficking. Traffic, 11 (12):1530-6, 2010. ISSN 1600-0854 (Electronic) 1398-9219 (Linking). doi: 10.1111/j.1600-0854.2010.01115.x. URL https://www.ncbi.nlm.nih.gov/pubmed/20874826.
[205] J. E. Schnitzer, P. Oh, E. Pinney, and J. Allard. Filipin-sensitive caveolae-mediated transport in endothelium: reduced transcytosis, scavenger endocytosis, and capillary permeability of select macromolecules. $J$ Cell Biol, 127(5):1217-32, 1994. ISSN 0021-9525 (Print) 00219525 (Linking). doi: 10.1083/jcb.127.5.1217. URL https://www.ncbi.nlm.nih.gov/pubmed/7525606.

[206] K. Seno, T. Okuno, K. Nishi, Y. Murakami, F. Watanabe, T. Matsuura, M. Wada, Y. Fujii, M. Yamada, T. Ogawa, T. Okada, H. Hashizume, M. Kii, S. Hara, S. Hagishita, S. Nakamoto, K. Yamada, Y. Chikazawa, M. Ueno, I. Teshirogi, T. Ono, and M. Ohtani. Pyrrolidine inhibitors of human cytosolic phospholipase a(2). J Med Chem, 43(6):1041-4, 2000. ISSN 0022-2623 (Print) 0022-2623 (Linking). doi: 10.1021/jm9905155. URL https://www.ncbi.nlm.nih.gov/pubmed/10737736.

[207] L. Shapiro, A. M. Fannon, P. D. Kwong, A. Thompson, M. S. Lehmann, G. Grubel, J. F. Legrand, J. AlsNielsen, D. R. Colman, and W. A. Hendrickson. Structural basis of cell-cell adhesion by cadherins. $\mathrm{Na}$ ture, 374(6520):327-37, 1995. ISSN 0028-0836 (Print) 0028-0836 (Linking). doi: 10.1038/374327a0. URL https://www.ncbi.nlm.nih.gov/pubmed/7885471.

[208] V. L. Sheen, V. S. Ganesh, M. Topcu, G. Sebire, A. Bodell, R. S. Hill, P. E. Grant, Y. Y. Shugart, J. Imitola, S. J. Khoury, R. Guerrini, and C. A. Walsh. Mutations in arfgef2 implicate vesicle trafficking in neural progenitor proliferation and migration in the human cerebral cortex. Nat Genet, 36(1):69-76, 2004. ISSN 1061-4036 (Print) 1061-4036 (Linking). doi: 10.1038/ng1276. URL https://www.ncbi.nlm.nih.gov/pubmed/14647276.

[209] E. A. Shelden, J. M. Weinberg, D. R. Sorenson, C. A. Edwards, and F. M. Pollock. Site-specific alteration of actin assembly visualized in living renal epithelial cells during atp depletion. $J$ Am Soc Nephrol, 13(11):266780, 2002. ISSN 1046-6673 (Print) 1046-6673 (Linking). doi: 10.1097/01.asn.0000033353.21502.31. URL https://www.ncbi.nlm.nih.gov/pubmed/12397036.

[210] L. Shen, C. R. Weber, and J. R. Turner. The tight junction protein complex undergoes rapid and continuous molecular remodeling at steady state. J Cell Biol, 181(4):683-95, 2008. ISSN 1540-8140 (Electronic) 00219525 (Linking). doi: 10.1083/jcb.200711165. URL https://www.ncbi.nlm.nih.gov/pubmed/18474622.

[211] A. Shilatifard, W. S. Lane, K. W. Jackson, R. C. Conaway, and J. W. Conaway. An rna polymerase ii elongation factor encoded by the human ell gene. Science, 271(5257):1873-6, 1996. ISSN 0036-8075 (Print) 00368075 (Linking). doi: 10.1126/science.271.5257.1873. URL https://www.ncbi.nlm.nih.gov/pubmed/8596958.

[212] K. Shin, S. Straight, and B. Margolis. Patj regulates tight junction formation and polarity in mammalian epithelial cells. J Cell Biol, 168(5):705-11, 2005. ISSN 0021-9525 (Print) 0021-9525 (Linking). doi: 10.1083/jcb.200408064. URL https://www.ncbi.nlm.nih.gov/pubmed/15738264.

[213] R. Shiomi, K. Shigetomi, T. Inai, M. Sakai, and J. Ikenouchi. Camkii regulates the strength of the epithelial barrier. Sci Rep, 5:13262, 2015. ISSN 2045-2322 (Electronic) 2045-2322 (Linking). doi: 10.1038/srep13262. URL https://www.ncbi.nlm.nih.gov/pubmed/26281891.

[214] T. Soldati, C. Rancano, H. Geissler, and S. R. Pfeffer. Rab7 and rab9 are recruited onto late endosomes by biochemically distinguishable processes. $J$ Biol Chem, 270(43):25541-8, 1995. ISSN 0021-9258 (Print) 00219258 (Linking). doi: 10.1074/jbc.270.43.25541. URL https://www.ncbi.nlm.nih.gov/pubmed/7592724. 
[215] T. Soma, H. Chiba, Y. Kato-Mori, T. Wada, T. Yamashita, T. Kojima, and N. Sawada. Thr(207) of claudin-5 is involved in size-selective loosening of the endothelial barrier by cyclic amp. Exp Cell Res, 300 (1):202-12, 2004. ISSN 0014-4827 (Print) 0014-4827 (Linking). doi: 10.1016/j.yexcr.2004.07.012. URL https://www.ncbi.nlm.nih.gov/pubmed/15383327.

[216] B. Somasundaram, J. C. Norman, and M. P. MahautSmith. Primaquine, an inhibitor of vesicular transport, blocks the calcium-release-activated current in rat megakaryocytes. Biochem J, 309 ( Pt 3):725-9, 1995. ISSN 0264-6021 (Print) 0264-6021 (Linking). doi: 10.1042/bj3090725. URL https://www.ncbi.nlm.nih.gov/pubmed/7639685.

[217] C. Staat, C. Coisne, S. Dabrowski, S. M. Stamatovic, A. V. Andjelkovic, H. Wolburg, B. Engelhardt, and I. E. Blasig. Mode of action of claudin peptidomimetics in the transient opening of cellular tight junction barriers. Biomaterials, 54:9-20, 2015. ISSN 1878-5905 (Electronic) 0142-9612 (Linking). doi: 10.1016/j.biomaterials.2015.03.007. URL https://www.ncbi.nlm.nih.gov/pubmed/25907035.

[218] S. M. Stagg, P. LaPointe, A. Razvi, C. Gurkan, C. S. Potter, B. Carragher, and W. E. Balch. Structural basis for cargo regulation of copii coat assembly. Cell, 134(3):474-84, 2008. ISSN 1097-4172 (Electronic) 00928674 (Linking). doi: 10.1016/j.cell.2008.06.024. URL https://www.ncbi.nlm.nih.gov/pubmed/18692470.

[219] S. M. Stamatovic, R. F. Keep, M. M. Wang, I. Jankovic, and A. V. Andjelkovic. Caveolae-mediated internalization of occludin and claudin-5 during ccl2-induced tight junction remodeling in brain endothelial cells. J Biol Chem, 284(28):19053-66, 2009. ISSN 0021-9258 (Print) 00219258 (Linking). doi: 10.1074/jbc.M109.000521. URL https://www.ncbi.nlm.nih.gov/pubmed/19423710.

[220] S. M. Stamatovic, N. Sladojevic, R. F. Keep, and A. V. Andjelkovic. Relocalization of junctional adhesion molecule a during inflammatory stimulation of brain endothelial cells. Mol Cell Biol, 32(17):3414-27, 2012. ISSN 1098-5549 (Electronic) 0270-7306 (Linking). doi: 10.1128/MCB.06678-11. URL https://www.ncbi.nlm.nih.gov/pubmed/22733993.

[221] T. Steinbacher, D. Kummer, and K. Ebnet. Junctional adhesion molecule-a: functional diversity through molecular promiscuity. Cell Mol Life Sci, 75(8):13931409,2018 . ISSN 1420-9071 (Electronic) 1420-682X (Linking). doi: 10.1007/s00018-017-2729-0. URL https://www.ncbi.nlm.nih.gov/pubmed/29238845.

[222] P. Sun, H. Yamamoto, S. Suetsugu, H. Miki, T. Takenawa, and T. Endo. Small gtpase rah/rab34 is associated with membrane ruffles and macropinosomes and promotes macropinosome formation. $J$ Biol Chem, 278(6):4063-71, 2003. ISSN 0021-9258 (Print) 00219258 (Linking). doi: 10.1074/jbc.M208699200. URL https://www.ncbi.nlm.nih.gov/pubmed/12446704.

[223] J. M. Sundstrom, B. R. Tash, T. Murakami, J. M. Flanagan, M. C. Bewley, B. A. Stanley, K. B. Gonsar, and D. A. Antonetti. Identification and analysis of occludin phosphosites: a combined mass spectrometry and bioinformatics approach. J Proteome Res, 8(2):808-17, 2009. ISSN 1535-3893 (Print) 1535-3893 (Linking). doi: 10.1021/pr7007913. URL https://www.ncbi.nlm.nih.gov/pubmed/19125584.

[224] T. Suzuki, B. C. Elias, A. Seth, L. Shen, J. R. Turner, F. Giorgianni, D. Desiderio, R. Guntaka, and R. Rao. $\mathrm{Pkc}$ eta regulates occludin phosphorylation and epithelial tight junction integrity. Proc Natl Acad Sci U S $A, 106(1): 61-6,2009$. ISSN 1091-6490 (Electronic) 00278424 (Linking). doi: 10.1073/pnas.0802741106. URL https://www.ncbi.nlm.nih.gov/pubmed/19114660.
[225] K. Tachibana, H. Nakanishi, K. Mandai, K. Ozaki, W. Ikeda, Y. Yamamoto, A. Nagafuchi, S. Tsukita, and Y. Takai. Two cell adhesion molecules, nectin and cadherin, interact through their cytoplasmic domain-associated proteins. $J$ Cell Biol, 150(5):1161-76, 2000. ISSN 0021-9525 (Print) 0021-9525 (Linking). doi: 10.1083/jcb.150.5.1161. URL https://www.ncbi.nlm.nih.gov/pubmed/10974003.

[226] K. Takahashi, H. Nakanishi, M. Miyahara, K. Mandai, K. Satoh, A. Satoh, H. Nishioka, J. Aoki, A. Nomoto, A. Mizoguchi, and Y. Takai. Nectin/prr: an immunoglobulinlike cell adhesion molecule recruited to cadherin-based adherens junctions through interaction with afadin, a pdz domain-containing protein. $J$ Cell Biol, 145 (3):539-49, 1999. ISSN 0021-9525 (Print) 00219525 (Linking). doi: 10.1083/jcb.145.3.539. URL https://www.ncbi.nlm.nih.gov/pubmed/10225955.

[227] S. Takahashi, N. Iwamoto, H. Sasaki, M. Ohashi, Y. Oda, S. Tsukita, and M. Furuse. The e3 ubiquitin ligase $\ln x 1 \mathrm{p} 80$ promotes the removal of claudins from tight junctions in mdck cells. J Cell Sci, 122(Pt 7):985-94, 2009. ISSN 0021-9533 (Print) 0021-9533 (Linking). doi: 10.1242/jcs.040055. URL https://www.ncbi.nlm.nih.gov/pubmed/19295125.

[228] K. Takekuni, W. Ikeda, T. Fujito, K. Morimoto, M. Takeuchi, M. Monden, and Y. Takai. Direct binding of cell polarity protein par-3 to cell-cell adhesion molecule nectin at neuroepithelial cells of developing mouse. $J$ Biol Chem, 278(8):5497-500, 2003. ISSN 0021-9258 (Print) 0021-9258 (Linking). doi: 10.1074/jbc.C200707200. URL https://www.ncbi.nlm.nih.gov/pubmed/12515806.

[229] J. W. Taraska, D. Perrais, M. Ohara-Imaizumi, S. Nagamatsu, and W. Almers. Secretory granules are recaptured largely intact after stimulated exocytosis in cultured endocrine cells. Proc Natl Acad Sci U S A, 100(4):2070-5, 2003. ISSN 0027-8424 (Print) 00278424 (Linking). doi: 10.1073/pnas.0337526100. URL https://www.ncbi.nlm.nih.gov/pubmed/12538853.

[230] J. Teng, T. Rai, Y. Tanaka, Y. Takei, T. Nakata, M. Hirasawa, A. B. Kulkarni, and N. Hirokawa. The kif3 motor transports n-cadherin and organizes the developing neuroepithelium. Nat Cell Biol, 7(5):474-82, 2005. ISSN 1465-7392 (Print) 1465-7392 (Linking). doi: 10.1038/ncb1249. URL https://www.ncbi.nlm.nih.gov/pubmed/15834408.

[231] T. Terai, N. Nishimura, I. Kanda, N. Yasui, and T. Sasaki. Jrab/mical-12 is a junctional rab13-binding protein mediating the endocytic recycling of occludin. Mol Biol Cell, 17(5):2465-75, 2006. ISSN 1059-1524 (Print) 10591524 (Linking). doi: 10.1091/mbc.e05-09-0826. URL https://www.ncbi.nlm.nih.gov/pubmed/16525024.

[232] M. A. Thoreson, P. Z. Anastasiadis, J. M. Daniel, R. C. Ireton, M. J. Wheelock, K. R. Johnson, D. K. Hummingbird, and A. B. Reynolds. Selective uncoupling of p120(ctn) from e-cadherin disrupts strong adhesion. $J$ Cell Biol, 148(1):189-202, 2000. ISSN 0021-9525 (Print) 0021-9525 (Linking). doi: 10.1083/jcb.148.1.189. URL https://www.ncbi.nlm.nih.gov/pubmed/10629228.

[233] D. Toullec, P. Pianetti, H. Coste, P. Bellevergue, T. GrandPerret, M. Ajakane, V. Baudet, P. Boissin, E. Boursier, F. Loriolle, and et al. The bisindolylmaleimide gf $109203 \mathrm{x}$ is a potent and selective inhibitor of protein kinase c. J Biol Chem, 266(24):15771-81, 1991. ISSN 0021-9258 (Print) 0021-9258 (Linking). URL https://www.ncbi.nlm.nih.gov/pubmed/1874734.

[234] A. Traweger, D. Fang, Y. C. Liu, W. Stelzhammer, I. A. Krizbai, F. Fresser, H. C. Bauer, and H. Bauer. The tight junction-specific protein occludin is a functional target of the e3 ubiquitin-protein ligase itch. J Biol Chem, 
277(12):10201-8, 2002. ISSN 0021-9258 (Print) 00219258 (Linking). doi: 10.1074/jbc.M111384200. URL https://www.ncbi.nlm.nih.gov/pubmed/11782481.

[235] I. S. Trowbridge, J. F. Collawn, and C. R. Hopkins. Signal-dependent membrane protein trafficking in the endocytic pathway. Annu Rev Cell Biol, 9:12961, 1993. ISSN 0743-4634 (Print) 0743-4634 (Linking). doi: 10.1146/annurev.cb.09.110193.001021. URL https://www.ncbi.nlm.nih.gov/pubmed/8280459.

[236] R. B. Troyanovsky, E. P. Sokolov, and S. M. Troyanovsky. Endocytosis of cadherin from intracellular junctions is the driving force for cadherin adhesive dimer disassembly. Mol Biol Cell, 17(8):3484-93, 2006. ISSN 1059-1524 (Print) 1059-1524 (Linking). doi: 10.1091/mbc.e06-03-0190. URL https://www.ncbi.nlm.nih.gov/pubmed/16760429.

[237] O. Ullrich, S. Reinsch, S. Urbe, M. Zerial, and R. G. Parton. Rab11 regulates recycling through the pericentriolar recycling endosome. J Cell Biol, 135(4):913-24, 1996. ISSN 0021-9525 (Print) 0021-9525 (Linking). doi: 10.1083/jcb.135.4.913. URL https://www.ncbi.nlm.nih.gov/pubmed/8922376.

[238] K. Umeda, J. Ikenouchi, S. Katahira-Tayama, K. Furuse, H. Sasaki, M. Nakayama, T. Matsui, S. Tsukita, M. Furuse, and S. Tsukita. Zo-1 and zo-2 independently determine where claudins are polymerized in tight-junction strand formation. Cell, 126(4):741-54, 2006. ISSN 0092-8674 (Print) 0092-8674 (Linking). doi: 10.1016/j.cell.2006.06.043. URL https://www.ncbi.nlm.nih.gov/pubmed/16923393.

[239] T. Urano, S. Fushida, K. Furukawa, and H. Shiku. Human nm23-h1-protein and h2-protein have similar nucleoside diphosphate kinase-activities. Int $J$ Oncol, 1(4):425-30, 1992. ISSN 1019-6439 (Print) 10196439 (Linking). doi: 10.3892/ijo.1.4.425. URL https://www.ncbi.nlm.nih.gov/pubmed/21584562.

[240] M. Utech, A. I. Ivanov, S. N. Samarin, M. Bruewer, J. R. Turner, R. J. Mrsny, C. A. Parkos, and A. Nusrat. Mechanism of ifn-gamma-induced endocytosis of tight junction proteins: myosin ii-dependent vacuolarization of the apical plasma membrane. Mol Biol Cell, 16(10):5040-52, 2005. ISSN 1059-1524 (Print) 10591524 (Linking). doi: 10.1091/mbc.e05-03-0193. URL https://www.ncbi.nlm.nih.gov/pubmed/16055505.

[241] C. M. Van Itallie, O. R. Colegio, and J. M. Anderson. The cytoplasmic tails of claudins can influence tight junction barrier properties through effects on protein stability. $J$ Membr Biol, 199(1):29-38, 2004. ISSN 0022-2631 (Print) 0022-2631 (Linking). doi: 10.1007/s00232-004-0673-z. URL https://www.ncbi.nlm.nih.gov/pubmed/15366421.

[242] C. M. Van Itallie, A. J. Tietgens, K. LoGrande, A. Aponte, M. Gucek, and J. M. Anderson. Phosphorylation of claudin-2 on serine 208 promotes membrane retention and reduces trafficking to lysosomes. J Cell Sci, 125 (Pt 20):4902-12, 2012. ISSN 1477-9137 (Electronic) 0021-9533 (Linking). doi: 10.1242/jcs.111237. URL https://www.ncbi.nlm.nih.gov/pubmed/22825868.

[243] C. M. Van Itallie, K. F. Lidman, A. J. Tietgens, and J. M. Anderson. Newly synthesized claudins but not occludin are added to the basal side of the tight junction. Mol Biol Cell, 30(12):1406-1424, 2019. ISSN 1939-4586 (Electronic) 1059-1524 (Linking). doi: 10.1091/mbc.E19-01-0008. URL https://www.ncbi.nlm.nih.gov/pubmed/30943107.

[244] M. Vietri, M. Radulovic, and H. Stenmark. The many functions of escrts. Nat Rev Mol Cell Biol, 21(1):25-42, 2020. ISSN 1471-0080 (Electronic) 14710072 (Linking). doi: 10.1038/s41580-019-0177-4. URL https://www.ncbi.nlm.nih.gov/pubmed/31705132.
[245] r. Wahl, J. K., Y. J. Kim, J. M. Cullen, K. R. Johnson, and M. J. Wheelock. N-cadherin-catenin complexes form prior to cleavage of the proregion and transport to the plasma membrane. J Biol Chem, 278(19):17269-76, 2003. ISSN 0021-9258 (Print) 0021-9258 (Linking). doi: 10.1074/jbc.M211452200. URL https://www.ncbi.nlm.nih.gov/pubmed/12604612.

[246] B. Wang, F. G. Wylie, R. D. Teasdale, and J. L. Stow. Polarized trafficking of e-cadherin is regulated by rac1 and cdc42 in madin-darby canine kidney cells. Am $J$ Physiol Cell Physiol, 288(6):C1411-9, 2005. ISSN 0363-6143 (Print) 0363-6143 (Linking). doi: 10.1152/ajpcell.00533.2004. URL https://www.ncbi.nlm.nih.gov/pubmed/15689411.

[247] L. Wang, G. Li, and S. Sugita. Rala-exocyst interaction mediates gtp-dependent exocytosis. J Biol Chem, 279(19):19875-81, 2004. ISSN 0021-9258 (Print) 00219258 (Linking). doi: 10.1074/jbc.M400522200. URL https://www.ncbi.nlm.nih.gov/pubmed/14978027.

[248] L. H. Wang, K. G. Rothberg, and R. G. Anderson. Misassembly of clathrin lattices on endosomes reveals a regulatory switch for coated pit formation. $J$ Cell Biol, 123(5):1107-17, 1993. ISSN 0021-9525 (Print) 00219525 (Linking). doi: 10.1083/jcb.123.5.1107. URL https://www.ncbi.nlm.nih.gov/pubmed/8245121.

[249] Q. Wang, X. W. Chen, and B. Margolis. Pals1 regulates e-cadherin trafficking in mammalian epithelial cells. Mol Biol Cell, 18(3):874-85, 2007. ISSN 1059-1524 (Print) 1059-1524 (Linking). doi: 10.1091/mbc.e06-07-0651. URL https://www.ncbi.nlm.nih.gov/pubmed/17182851.

[250] M. Weber, M. Uguccioni, M. Baggiolini, I. Clark-Lewis, and C. A. Dahinden. Deletion of the nh2-terminal residue converts monocyte chemotactic protein 1 from an activator of basophil mediator release to an eosinophil chemoattractant. $J$ Exp Med, 183(2):681-5, 1996. ISSN 0022-1007 (Print) 0022-1007 (Linking). doi: 10.1084/jem.183.2.681. URL https://www.ncbi.nlm.nih.gov/pubmed/8627182.

[251] E. Welman and T. J. Peters. Prevention of lysosome disruption in anoxic myocardium by chloroquine and methyl prednisolone. Pharmacol Res Commun, 9 (1):29-38, 1977. ISSN 0031-6989 (Print) 0031-6989 (Linking). doi: 10.1016/s0031-6989(77)80051-9. URL https://www.ncbi.nlm.nih.gov/pubmed/866359.

[252] P. Whitley, B. J. Reaves, M. Hashimoto, A. M. Riley, B. V. Potter, and G. D. Holman. Identification of mammalian vps24p as an effector of phosphatidylinositol 3,5bisphosphate-dependent endosome compartmentalization. $J$ Biol Chem, 278(40):38786-95, 2003. ISSN 0021-9258 (Print) 0021-9258 (Linking). doi: 10.1074/jbc.M306864200. URL https://www.ncbi.nlm.nih.gov/pubmed/12878588.

[253] W. Xia, E. W. Wong, D. D. Mruk, and C. Y. Cheng. Tgf-beta3 and tnfalpha perturb blood-testis barrier (btb) dynamics by accelerating the clathrin-mediated endocytosis of integral membrane proteins: a new concept of btb regulation during spermatogenesis. Dev Biol, 327 (1):48-61, 2009. ISSN 1095-564X (Electronic) 00121606 (Linking). doi: 10.1016/j.ydbio.2008.11.028. URL https://www.ncbi.nlm.nih.gov/pubmed/19103189.

[254] K. Xiao, D. F. Allison, M. D. Kottke, S. Summers, G. P. Sorescu, V. Faundez, and A. P. Kowalczyk. Mechanisms of ve-cadherin processing and degradation in microvascular endothelial cells. J Biol Chem, 278(21):19199-208, 2003. ISSN 0021-9258 (Print) 00219258 (Linking). doi: 10.1074/jbc.M211746200. URL https://www.ncbi.nlm.nih.gov/pubmed/12626512.

[255] K. Xiao, J. Garner, K. M. Buckley, P. A. Vincent, C. M. Chiasson, E. Dejana, V. Faundez, and 
A. P. Kowalczyk. p120-catenin regulates clathrindependent endocytosis of ve-cadherin. Mol Biol Cell, 16(11):5141-51, 2005. ISSN 1059-1524 (Print) 10591524 (Linking). doi: 10.1091/mbc.e05-05-0440. URL https://www.ncbi.nlm.nih.gov/pubmed/16120645.

[256] Z. Xu, R. Waeckerlin, M. D. Urbanowski, G. van Marle, and T. C. Hobman. West nile virus infection causes endocytosis of a specific subset of tight junction membrane proteins. PLoS One, 7(5):e37886, 2012. ISSN 1932-6203 (Electronic) 19326203 (Linking). doi: 10.1371/journal.pone.0037886. URL https://www.ncbi.nlm.nih.gov/pubmed/22655077.

[257] M. Yamamoto, S. H. Ramirez, S. Sato, T. Kiyota, R. L. Cerny, K. Kaibuchi, Y. Persidsky, and T. Ikezu. Phosphorylation of claudin- 5 and occludin by rho kinase in brain endothelial cells. Am J Pathol, 172(2):521-33, 2008. ISSN 0002-9440 (Print) 0002-9440 (Linking). doi: 10.2353/ajpath.2008.070076. URL https://www.ncbi.nlm.nih.gov/pubmed/18187566.

[258] R. Yamamura, N. Nishimura, H. Nakatsuji, S. Arase, and T. Sasaki. The interaction of jrab/mical-12 with rab8 and rab13 coordinates the assembly of tight junctions and adherens junctions. Mol Biol Cell, 19 (3):971-83, 2008. ISSN 1939-4586 (Electronic) 10591524 (Linking). doi: 10.1091/mbc.e07-06-0551. URL https://www.ncbi.nlm.nih.gov/pubmed/18094055.

[259] Z. Yan, Z. G. Wang, N. Segev, S. Hu, R. D. Minshall, R. O. Dull, M. Zhang, A. B. Malik, and G. Hu. Rab11a mediates vascular endothelial-cadherin recycling and controls endothelial barrier function. Arterioscler Thromb Vasc Biol, 36(2):339-49, 2016. ISSN 1524-4636 (Electronic) 10795642 (Linking). doi: 10.1161/ATVBAHA.115.306549. URL https://www.ncbi.nlm.nih.gov/pubmed/26663395.

[260] M. Yanagisawa, I. N. Kaverina, A. Wang, Y. Fujita, A. B. Reynolds, and P. Z. Anastasiadis. A novel interaction between kinesin and p120 modulates p120 localization and function. $J$ Biol Chem, 279(10):9512-21, 2004. ISSN 0021-9258 (Print) 0021-9258 (Linking). doi: 10.1074/jbc.M310895200. URL https://www.ncbi.nlm.nih.gov/pubmed/14676216.

[261] A. S. Yap, C. M. Niessen, and B. M. Gumbiner. The juxtamembrane region of the cadherin cytoplasmic tail supports lateral clustering, adhesive strengthening, and interaction with p120ctn. J Cell Biol, 141(3):779-89, 1998. ISSN 00219525 (Print) 0021-9525 (Linking). doi: 10.1083/jcb.141.3.779. URL https://www.ncbi.nlm.nih.gov/pubmed/9566976.

[262] A. S. Yap, M. S. Crampton, and J. Hardin. Making and breaking contacts: the cellular biology of cadherin regulation. Curr Opin Cell Biol, 19(5):508-14, 2007. ISSN 0955-0674 (Print) 0955-0674 (Linking). doi: 10.1016/j.ceb.2007.09.008. URL https://www.ncbi.nlm.nih.gov/pubmed/17935963.

[263] A. S. Yap, G. A. Gomez, and R. G. Parton. Adherens junctions revisualized: Organizing cadherins as nanoassemblies. Dev Cell, 35(1):12-20, 2015. ISSN 1878-1551 (Electronic) 1534-5807 (Linking). doi: 10.1016/j.devcel.2015.09.012. URL https://www.ncbi.nlm.nih.gov/pubmed/26460944.

[264] P. Yin, Y. Li, and L. Zhang. Sec24c-dependent transport of claudin-1 regulates hepatitis c virus entry. $J$ Virol, 91(18), 2017. ISSN 1098-5514 (Electronic) 0022538X (Linking). doi: 10.1128/JVI.00629-17. URL https://www.ncbi.nlm.nih.gov/pubmed/28679754.

[265] S. Yokoyama, K. Tachibana, H. Nakanishi, Y. Yamamoto, K. Irie, K. Mandai, A. Nagafuchi, M. Monden, and Y. Takai. alpha-catenin-independent recruitment of zo-1 to nectin-based cell-cell adhesion sites through afadin. $\mathrm{Mol}$ Biol Cell, 12(6):1595-609, 2001. ISSN 1059-1524 (Print) 1059-1524 (Linking). doi: 10.1091/mbc.12.6.1595. URL https://www.ncbi.nlm.nih.gov/pubmed/11408571.
[266] T. Yoshimori, A. Yamamoto, Y. Moriyama, M. Futai, and Y. Tashiro. Bafilomycin a1, a specific inhibitor of vacuolartype $\mathrm{h}(+)$-atpase, inhibits acidification and protein degradation in lysosomes of cultured cells. J Biol Chem, 266(26): 17707-12, 1991. ISSN 0021-9258 (Print) 0021-9258 (Linking). URL https://www.ncbi.nlm.nih.gov/pubmed/1832676.

[267] J. S. Young, Y. Takai, K. L. Kojic, and A. W. Vogl. Internalization of adhesion junction proteins and their association with recycling endosome marker proteins in rat seminiferous epithelium. Reproduction, 143 (3):347-57, 2012. ISSN 1741-7899 (Electronic) 14701626 (Linking). doi: 10.1530/REP-11-0317. URL https://www.ncbi.nlm.nih.gov/pubmed/22157319.

[268] M. Yu, S. Yang, Y. Qiu, G. Chen, W. Wang, C. Xu, W. Cai, L. Sun, W. Xiao, and H. Yang. Par-3 modulates intestinal epithelial barrier function through regulating intracellular trafficking of occludin and myosin light chain phosphorylation. $J$ Gastroenterol, 50(11):1103-13, 2015. ISSN 1435-5922 (Electronic) 0944-1174 (Linking). doi: 10.1007/s00535-015-1066-z. URL https://www.ncbi.nlm.nih.gov/pubmed/25820151.

[269] G. N. Zecherle, A. Oleinikov, and R. R. Traut. The proximity of the c-terminal domain of escherichia coli ribosomal protein $17 / 112$ to 110 determined by cysteine site-directed mutagenesis and protein-protein cross-linking. J Biol Chem, 267(9):588996, 1992. ISSN 0021-9258 (Print) 0021-9258 (Linking). URL https://www.ncbi.nlm.nih.gov/pubmed/1556104.

[270] C. Zihni, C. Mills, K. Matter, and M. S. Balda. Tight junctions: from simple barriers to multifunctional molecular gates. Nat Rev Mol Cell Biol, 17(9):564-80, 2016. ISSN 1471-0080 (Electronic) 1471-0072 (Linking). doi: 10.1038/nrm.2016.80. URL https://www.ncbi.nlm.nih.gov/pubmed/27353478. 